\title{
FAULT SEGMENTATION AND PALEOSEISMICITY ALONG THE NORTH WUTAISHAN FAULT OF THE SHANXI GRABEN SYSTEM, CHINA
}

A Thesis
Presented to
the Faculty of the Graduate School
at the University of Missouri-Columbia
In Partial Fulfillment
of the Requirements for the Degree
Master of Science
Dr. Francisco Gomez, Thesis Supervisor
MAY 2013


The undersigned, appointed by the dean of the Graduate School, have examined the thesis entitled:

Fault Segmentation and Paleoseismicity along the North Wutaishan

Fault of the Shanxi Graben System, China

Presented by Nathan Hinrichs

A candidate for the degree of Master of Science

And hereby certify that, in their opinion, it is worthy of acceptance.

Dr. Francisco Gomez

Dr. Robert Bauer

Dr. Michael Urban 
This thesis is dedicated to my wife and son, whose continuous support has propelled me through the present and into our future. 


\section{ACKNOWLEDGEMENTS}

I would like to thank my thesis advisor, Dr. Francisco Gomez, for his support and assistance with all aspects of the thesis process. I would also like to thank my committee members, Dr. Robert Bauer and Dr. Michael Urban, for their advice and support throughout the writing process. I would like to thank Dr. Shimin Zhang, Rui Ding, Liyuan Zhao, Hanyong Liu, John Corley and William Cochran for their extensive assistance with my field work in China. I would also like to thank the National Science Foundation for providing the funding for my research, as well as the University of Missouri Department of Geologic Sciences for providing scholarship support. Finally, I would like to thank my friends and family for their continuous support throughout the thesis process. 


\section{TABLE OF CONTENTS}

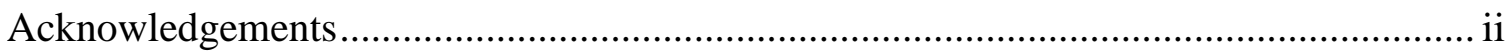

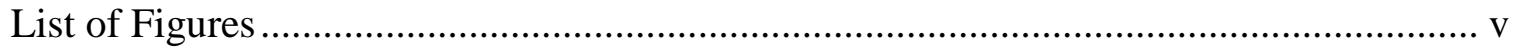

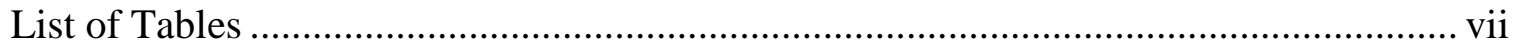

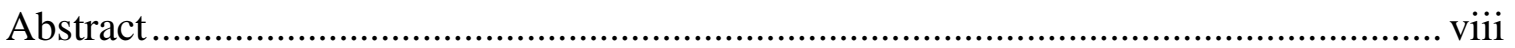

Chapter 1: Introduction and Research Questions ................................................... 1

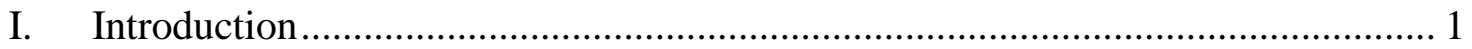

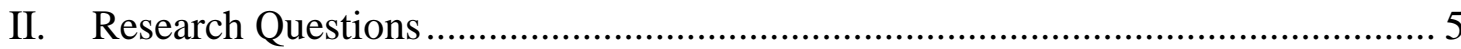

Chapter 2: Geologic Background of the Shanxi Graben System................................... 6

I. Precambrian Geology of the Wutaishan Area of the North China Craton ............. 6

A. Formation of the North China Craton.......................................................... 6

B. Precambrian Lithology of the Study Area ................................................ 10

II. Formation of the Shanxi Graben System ................................................... 12

III. Active Tectonics in the Shanxi Graben System........................................... 15

A. The Shanxi Region ............................................................................ 15

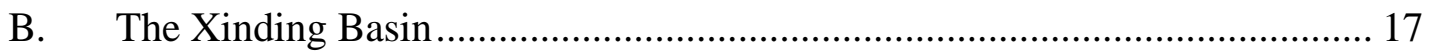

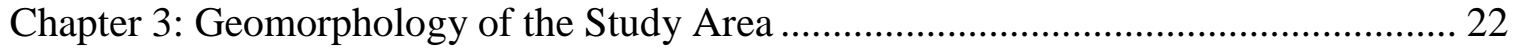

I. Fault Trace Mapping and Trench Site Selection........................................ 22

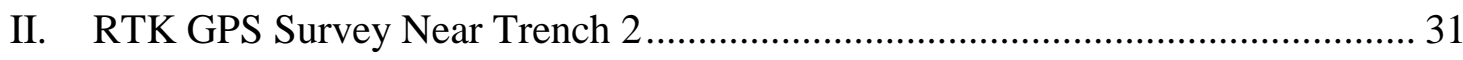

Chapter 4: Paleoseismic Trench Investigation......................................................... 37 
I. Trench Excavation and Preparation ............................................................ 37

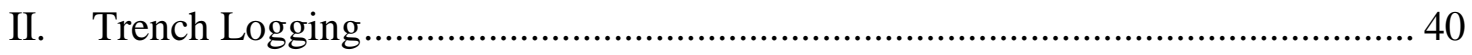

III. Trench 1 - Zhong Zhuang Zhai Trench ............................................................ 44

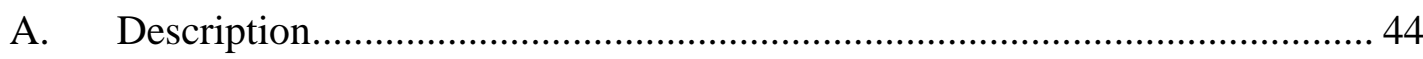

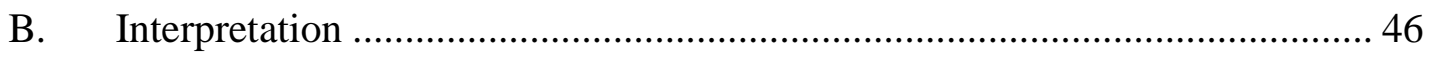

IV. Trench 2 - NBT - Large Trench ................................................................ 52

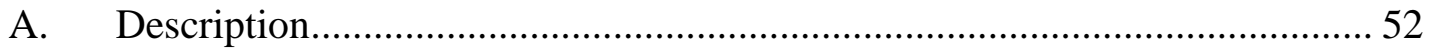

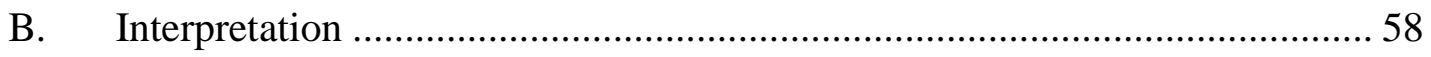

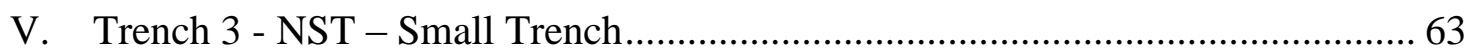

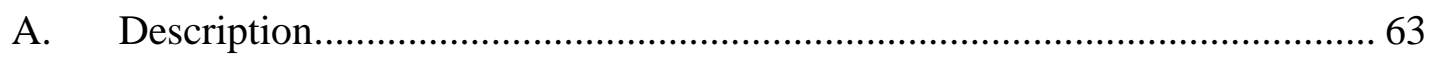

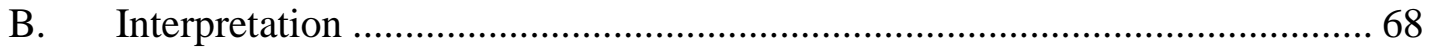

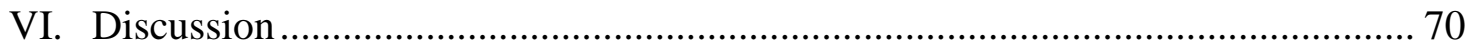

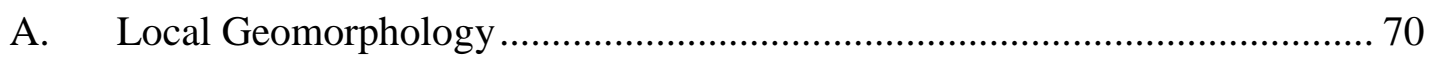

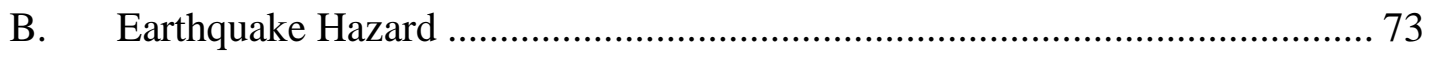

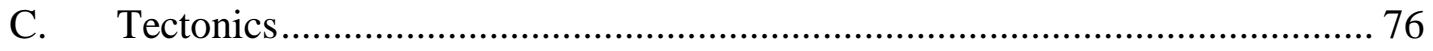

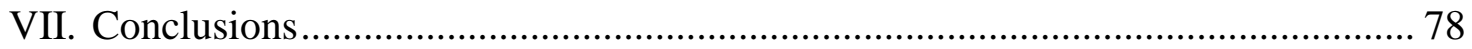

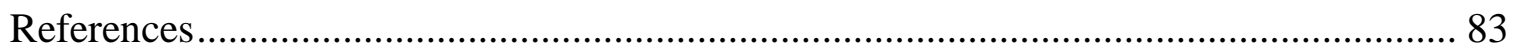




\section{LIST OF FIGURES}

Figure 1.1 Location of the North China Craton and the Shanxi Graben System.................2

Figure 1.2 Orientation of faults in the Shanxi Province of North China ...........................

Figure 2.1 Simplified tectonic map of the North China Craton .....................................

Figure 2.2 Formation of the North China Craton and Wutai Complex ............................

Figure 2.3 Simplified regional geology of the Hengshan-Wutai-Fuping area..................11

Figure 2.4 Simplified Cenozoic stratigraphic column from the Weihe basin...................14

Figure 2.5 GPS velocities surrounding the Shanxi Graben System...............................16

Figure 2.6 Historical and recent seismicity for the Shanxi Graben System ...................18

Figure 3.1 Cartosat imagery footprints on a DEM of the Daixian Basin ........................23

Figure 3.2 Fault trace mapping of the North Wutaishan Fault in the Daixian Basin ........24

Figure 3.3 Location of the study area along the North Wutaishan Fault .........................26

Figure 3.4 The geomorphology of the area surrounding Trench 1 ..............................28

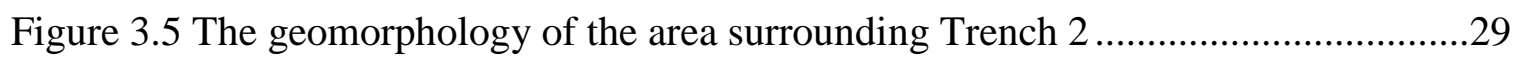

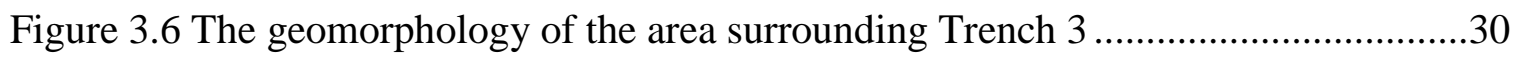

Figure 3.7 The location of the RTK GPS survey of the area around Trench 2 ...............32

Figure 3.8 An interpolated DEM of the RTK GPS survey of the area around Trench $2 . . .33$

Figure 3.9 Profile plots across two faulted relict fluvial terrace surfaces........................34

Figure 4.1 Trench styles used in paleoseismic investigation .....................................38

Figure 4.2 The dimensions of all three trenches excavated for this study ......................39

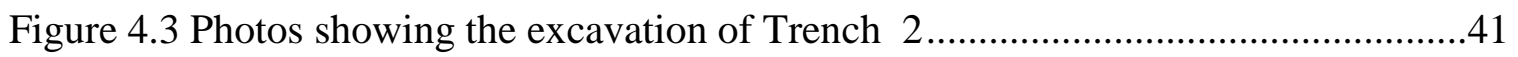

Figure 4.4 Model used to generate orthorectified photos of the trench walls...................42

Figure 4.5 Annotated photo of Trench 1 from the north..........................................45 
Figure 4.6 Image of the west wall of Trench 1

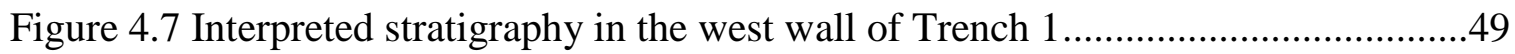

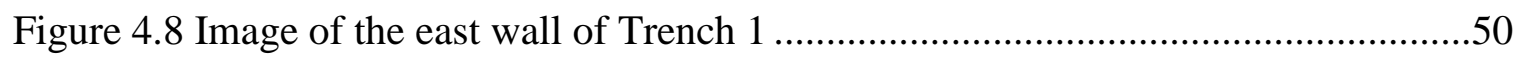

Figure 4.9 Annotated photo of Trench 2 from the north............................................53

Figure 4.10 Stratigraphy of the lower three meters on the south side of the west wall .....54

Figure 4.11 Image and interpreted stratigraphy of the west wall of Trench $2 \ldots \ldots \ldots \ldots \ldots \ldots . . .56$

Figure 4.12 Interpreted stratigraphy in the west wall of Trench $2 \ldots \ldots \ldots \ldots \ldots \ldots \ldots \ldots \ldots \ldots \ldots . . .57$

Figure 4.13 Image and interpreted stratigraphy of the east wall of Trench $2 \ldots \ldots \ldots \ldots \ldots \ldots . . .59$

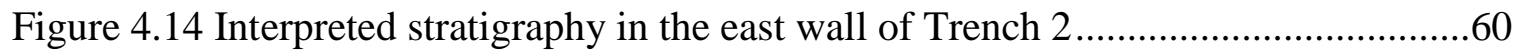

Figure 4.15 Annotated photo of the southern wall of Trench 2 ..................................64

Figure 4.16 Annotated photo of Trench 3 from the north..........................................65

Figure 4.17 Image and interpreted stratigraphy of the west wall of Trench $3 \ldots \ldots \ldots \ldots \ldots . . .66$

Figure 4.18 Interpreted stratigraphy in the west wall of Trench $3 \ldots \ldots \ldots \ldots \ldots \ldots \ldots \ldots \ldots \ldots \ldots . . .67$

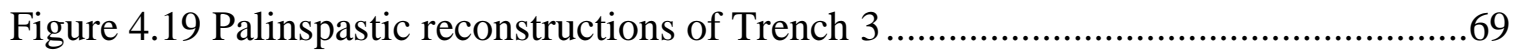




\section{LIST OF TABLES}

Table 2.1 Timing of the last 6 earthquake events on the North Wutaishan Fault..............20

Table 4.1 Calendar calibrated radiocarbon ages of samples from Trenches $1 \& 2 \ldots \ldots \ldots . .47$

Table 4.2 Error propagation applied to the timing of the last 6 earthquake events ...........75 


\title{
Fault Segmentation and Paleoseismicity along the North Wutaishan Fault of the Shanxi Graben System, China
}

\author{
Nathan Hinrichs \\ Dr. Francisco Gomez, Thesis Supervisor
}

\begin{abstract}
The Shanxi Graben System has been the location of large, devastating intraplate earthquakes in the past, making it an ideal location for the study of the temporal recurrence of intracontinental earthquakes. This study conducts a paleoseismic investigation on the North Wutaishan Fault (NWTSF) at the Northeastern end of the graben system. Located in North China between the Ordos Plateau and the Taihang Mountains, the Shanxi Graben System is composed of a series of en echelon left-stepping half graben basins oriented roughly to the North-Northeast. The NWTSF fault is an $85 \mathrm{~km}$ long normal fault, bordering the southern edge of the Daixian basin. The fault trace was mapped using high resolution satellite imagery. Three trenches were excavated for paleoseismic and slip rate investigations on a $4.5 \mathrm{~km}$ long section of the fault located at the eastern end of the basin. Two of the three trenches had a depth and length of $\sim 8$ and 16 meters respectively while the other had a depth and length of 1.5 and 3 meters. Anthropogenic modification and large amounts of erosion eliminated evidence of the most recent earthquake event at all trench sites. A paleoslope identified in one of the trenches suggests a large amount of sedimentation in addition to the large amount of erosion, possibly due to the lateral migration of the Yangyan River to the north of the study area. A significant change in stratigraphy from the west to the east wall of one of the trenches is a result of interaction from drainages to the east. A large alluvial fan
\end{abstract}


deflected water from a drainage to the east of the trench, causing it to flow along the scarp, eroding part of the trench, while gravel layers were deposited from the fan, dipping southward, away from the basin. A Real Time Kinematic GPS survey of the area surrounding one of the trench sites highlighted two relict stream terraces that were faulted. These terraces show two paleoseismic events with vertical offsets of 2.9 and 2.5 meters, which equate to moment magnitudes of 7.1M and 7.0-7.1M respectively. Smaller offsets of 0.69 and 0.91 meters were observed in the small trench, though additional slip on faults not visible in the trench is a possibility. An estimated slip rate of $0.7-0.9 \mathrm{~mm} / \mathrm{yr}$ was calculated from the restoration of a radiocarbon dated paleosol $(19 \pm 0.025 \mathrm{kaBP})$ with a similarly aged T2 surface $(\sim 18 \pm 0.9 \mathrm{kaBP})$. An additional estimate of slip rate of $1.3 \pm 0.5$ $\mathrm{mm} / \mathrm{yr}$ was calculated using the offset relict terraces and an average earthquake recurrence interval from previously published data. From these two slip rate measurements horizontal rates of extension of $0.4-0.7$ and $0.7 \mathrm{~mm} / \mathrm{yr}$ were calculated. These values are consistent with other measurements of extension across the Shanxi Graben System as well as within extensional constraints of $<1.5 \mathrm{~mm} / \mathrm{yr}$ as implied by GPS velocity studies in the area. Estimates of $0.5 \pm 0.1 \mathrm{~mm} / \mathrm{yr}$ of extension from the uppermost Pliocene to the Quaternary across the graben system suggest that the region has shown a consistent rate of extension since at least the late Pliocene. 


\section{Chapter 1: Introduction and Research Questions}

\section{Introduction}

The Shanxi province of North China has been the location of multiple large and devastating intraplate earthquakes in the past making it ideal for the study of the temporal recurrence of intracontinental earthquakes (Figure 1.1). Whereas the majority of seismic activity occurs along plate boundaries, earthquakes in intracontinental settings can be just as devastating, if not more, since they may occur in unexpected places. Deformation styles and kinematics for intracontinental earthquakes can be complex, with earthquake events occurring sporadically.

This study focuses on the North Wutaishan Fault (NWTSF) at the Northeastern end of the Shanxi Graben System. The most recent earthquake on this fault is thought to be the $M=7.5$ Daixian Earthquake in 512 A.D. though the full extent of the surface rupture is unknown. The surface trace of the NWTSF and the geomorphology of the mountain front were mapped using a combination of Google Earth and Cartosat imagery. The mapping provided a context for the selection of trench site locations suitable to the preservation of recently faulted stratigraphy. Trenches were excavated for paleoseismic study across the NWTSF in order to investigate earthquake event timing and frequency. Estimated fault magnitudes from scarp profiles obtained at one of the trench sites will help in future assessment of seismic risk for this portion of the NWTSF.

The Shanxi Graben System is composed of a series of en echelon, left stepping half graben basins that trend roughly to the North Northeast (Figure 1.2). The majority of faults in the graben system are normal faults, while right lateral strike slip faults connect the major basins and strike generally north south. The orientation of faults in the Shanxi 

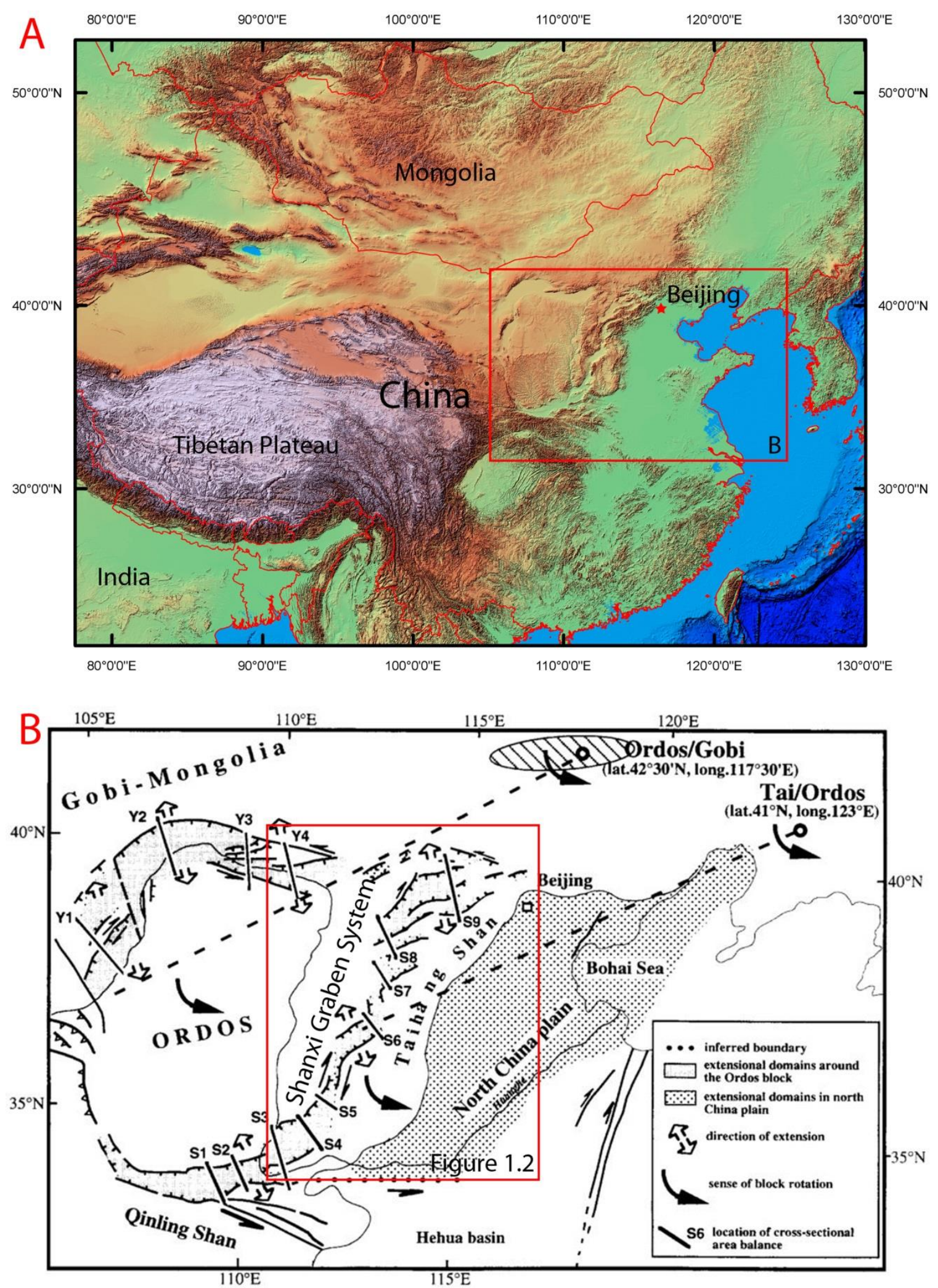

Figure 1.1 Location of the North China Craton (A) including the Shanxi Graben System and its surrounding blocks (B). Counterclockwise rotation is shown in both the Ordos and Taihang Mountain blocks thought to be caused by Tibetan escape tectonics (B, Modified from Li et al. (1998)). 


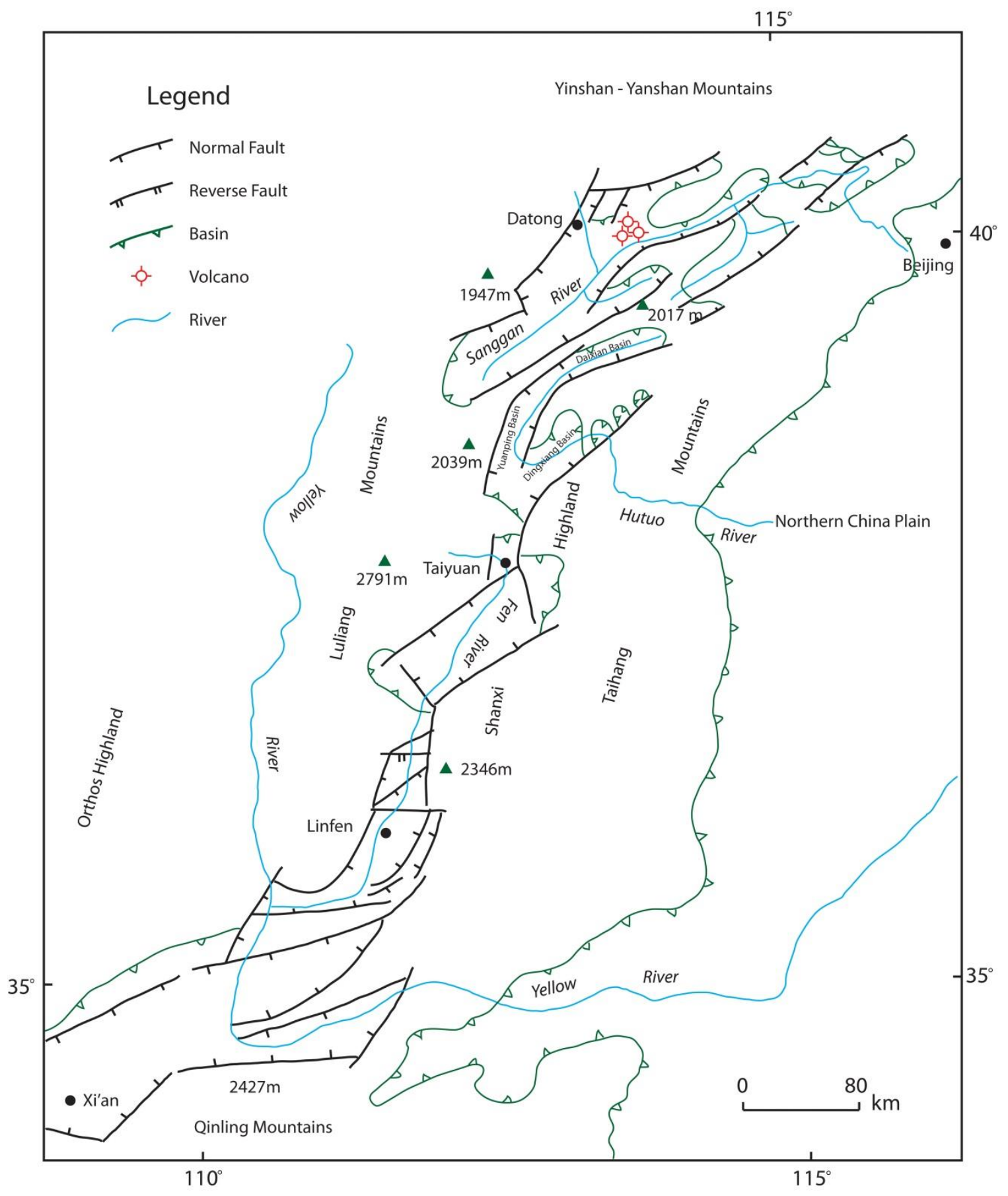

Figure 1.2 Type and orientation of faults in the Shanxi Province of North China. Modified from Li et al. (1998). 
Graben System is thought to be influenced by the Cenozoic India - Eurasia collision (Liu et al., 2011; Zhang et al., 1998).

Historically destructive earthquakes in the Shanxi Graben System motivate paleoseismic study in the region. Chinese historical records document $21 \quad \mathrm{M} \geq 6$ earthquake events including four $\mathrm{M} \geq 7$ events within the graben system (Liu et al., 2007; $\mathrm{Xu}$ et al., 1993). Among these was the $\mathrm{M} \geq 8$ Huaxian earthquake of 1556 where an estimated 830,000 people were killed (He et al., 2003). An understanding of the timing and frequency of earthquakes in the region is necessary for any earthquake risk assessment or earthquake preparation measures to be accomplished. Earthquake magnitudes determined by paleoseismic investigation and supported by Chinese historical records can allow buildings to be constructed that will be able to withstand earthquakes of those magnitudes, while earthquake recurrence intervals along specific faults assisting in risk assessment for vital structures built near these faults.

The potential for the alteration and/or destruction of vital stratigraphy and geomorphology by human modification (e.g. cultivation) or other natural phenomena must be assessed if any paleoseismic trench work is to be successful. Analyzing the three-dimensional geometry of the stratigraphy in one of the trenches helps in the understanding of late Quaternary basin edge sedimentary processes. Examination of logs from this trench as well as others from the area will show the extent to which the fault scarp and shallow subsurface has been directly altered by human activity. This also allows more accurate selection of favorable trench sites for the preservation of faulted stratigraphy in the future. 


\section{Research Questions}

Key research questions addressed in this thesis include:

- When was the last earthquake event recorded on the NWTSF near Nanyukou village? What was the magnitude of this event? Did the M7.5 Daixian earthquake in $512 \mathrm{AD}$ rupture on the surface as far northeast as Nanyukou Village along the NWTSF? The extent of the fault rupture would provide an alternative method for estimating the magnitude of the last earthquake event. Additional estimations for fault magnitude and timing of events will help improve the spatial record (extent) of past earthquake events on the NWTSF.

- To what extent has the NWTSF scarp been affected by human modification (e.g. terracing for cultivation) in this area? The amount of human modification in the area will alter future trench site selections on a local scale.

- In regard to late Quaternary basin sedimentary processes, how may adjacent drainage networks affect each other with respect to earthquake derived sediment preservation?

- How does the paleoseismic earthquake record of moment release compare with GPS-based measurements of strain? What is the mean recurrence time and characteristic magnitude of earthquakes along the NWTSF? Discrepancies between GPS measurements of strain and the earthquake record help identify weaknesses in either dataset such as time scale dependency of GPS measurements or strain that is unaccounted for in a given basin. 


\section{Chapter 2: Geologic Background of the Shanxi Graben System}

The Shanxi Graben System, part of the North China Craton (NCC), is bordered by the Ordos Plateau to the west and the Taihang Mountains to the East, with the Tibetan Plateau to the west-southwest (Figure 1.1). In order to better understand the tectonic activity in a given region, a review of the formation and composition of that region is necessary.

\section{Precambrian Geology of the Wutaishan Area of the North China Craton}

Though not much is known about the Precambrian Geology of the NCC before $3.8 \mathrm{Ga}$, there is a rich and complex record of deformation, magmatism and sedimentation since then. Multiple hypotheses have been proposed for the formation of the NCC, with the main differences between them involving timing of the events. This review of Precambrian Geology focuses on the Wutaishan Area of the NCC, where this study is located.

\section{A. Formation of the North China Craton}

There are two major competing models that deal with the formation of the NCC and the Hengshan-Wutai-Fuping complex in which our study area is located. The first model is outlined in Zhao et al. (2007) and has been one of the more popular models over the last decade (Kusky, 2011). Their model divides the NCC into two separate blocks, the western and eastern blocks, with an orogenic belt between the two termed the TransNorth China Orogen (TNCO)(Figure 2.1). They suggest that, starting around $2.56 \mathrm{Ga}$, the western block was subducted under the eastern block in a continuous Andean-type subduction that lasted approximately $650 \mathrm{Ma}$. The Hengshan-Wutai-Fuping complex represents part of a series of magmatic arcs that formed during this long lived subduction 


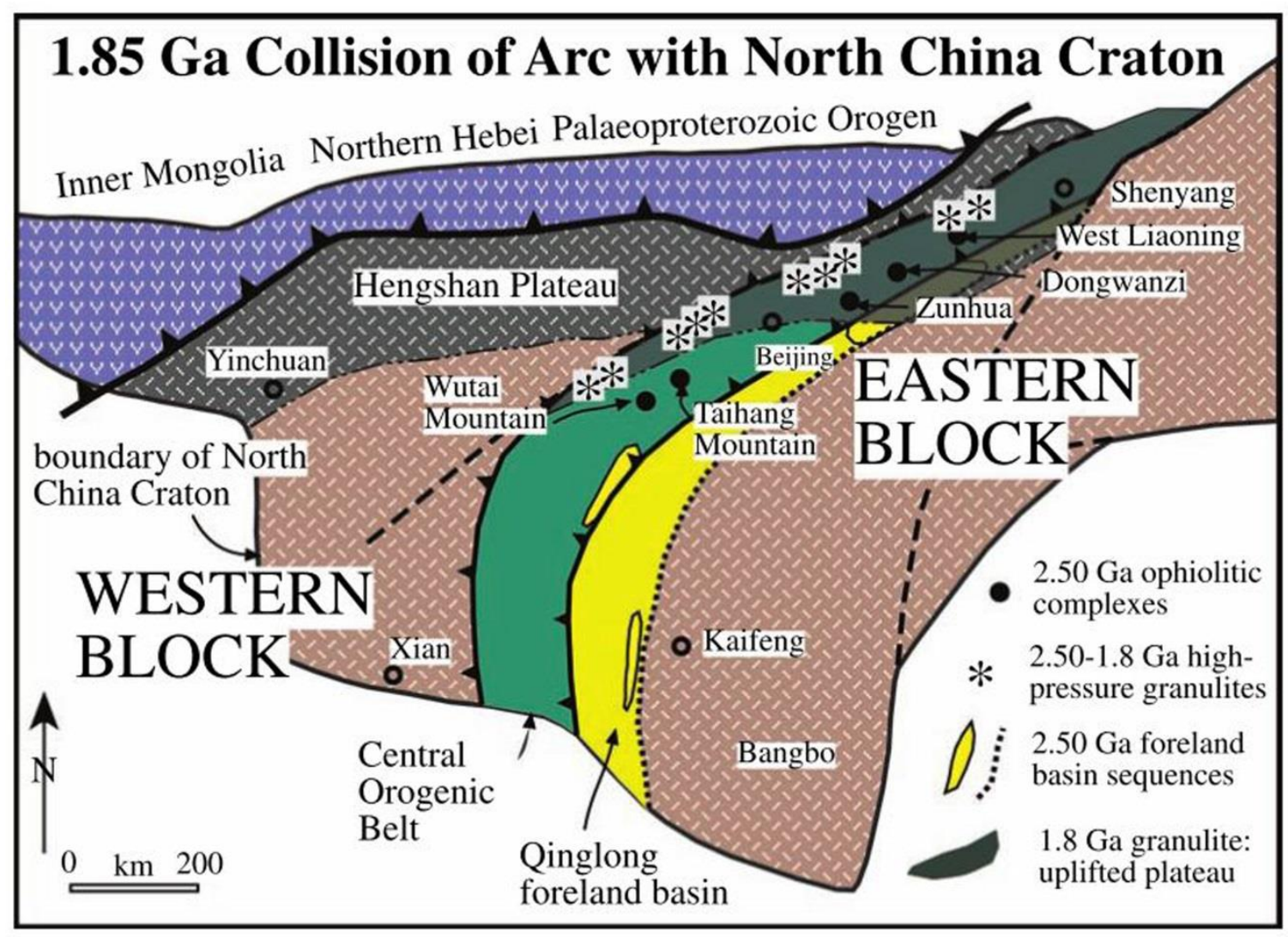

Figure 2.1 Simplified tectonic map of the North China Craton. Zhao et al. (2007) label the Central Orogenic Belt as the 'Trans North China Orogen' with similar boundaries. From Kusky et al. (2007). 
process. Between 1.88 and 1.82 Ga the western and eastern blocks collided, incorporating the Hengshan-Wutai-Fuping complex into the TNCO.

The second model for the formation is outlined in Kusky (2011)(Figure 2.2). Kusky (2011) divided the NCC into eastern and western blocks similar to Zhao et al. (2007) but termed the orogen separating the two blocks as the Central Orogenic Belt (COB). The extent of the $\mathrm{COB}$ was delineated using Archean geology rather than by the extent of Mesozoic faulting that defines the TNCO. In this model the western edge of the eastern block was subducted under the Wutai arc terrain until their subsequent collision around 2.5 Ga. Eastward subduction then initiated on the western side of the Wutai arc with the possibility of westward subduction continuing under the western block until the collision of the western block with the Wutai arc and eastern block around $2.3-2.2 \mathrm{Ga}$. Finally, around $1.8 \mathrm{Ga}$, there was high grade metamorphism and uplift of the Wutai complex and surrounding areas due to the collision of the Columbia Supercontinent with the NCC from the north. This model was presented by Kusky (2011) and is an updated version of previous models described in Kusky (2011), Kusky et al. (2007) and Kusky and Li (2003). The model takes into account recent seismic imaging presented by Zheng et al. (2010) that shows westward dipping subduction across the NCC.

Evidence of intense deformation and many shear zones previously thought to be unconformities suggests that the Wutai complex was formed during a major collisional event (Kröner et al., 2005). The major difference between models for the Precambrian formation of the NCC is the timing of this event. Zhao et al. (2007) and Kröner et al. (2005) put the collision between the western and eastern blocks in the Paleoproterozoic around $1.88-1.82 \mathrm{Ga}$, with eastward subduction the entire time. Kusky (2011) suggests 


\section{$2.55 \mathrm{Ga}$}

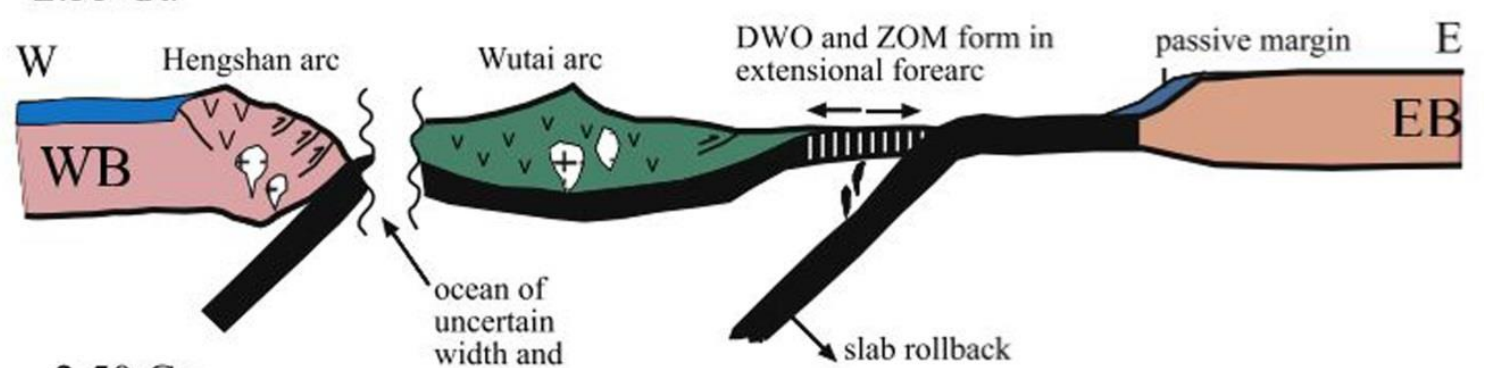

\section{$2.50 \mathrm{Ga}$}

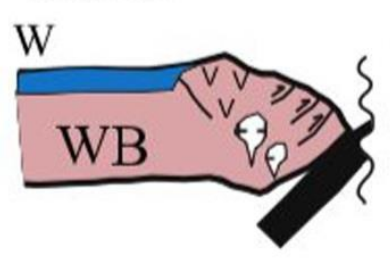

width and relation to $\mathrm{NCC}$ at this 2.50-2.40 Ga W time
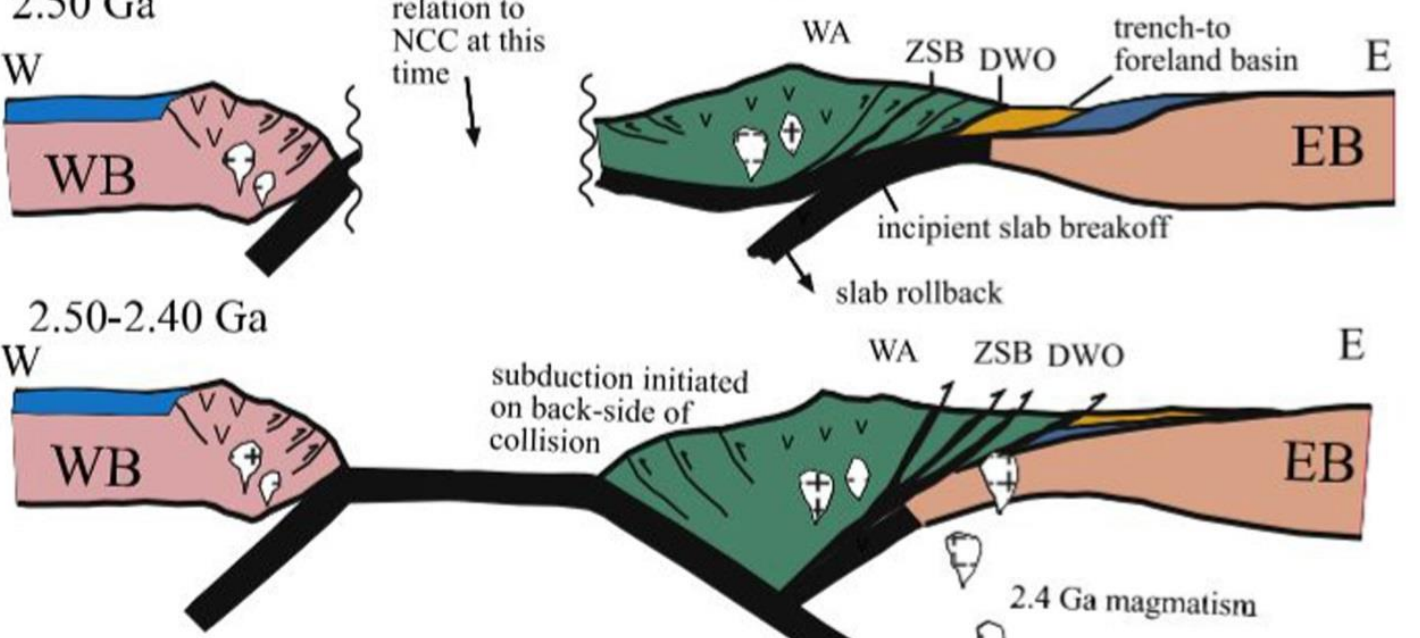

$$
\text { subduction initiated }
$$

WA ZSB DWO

E on back-side of collision
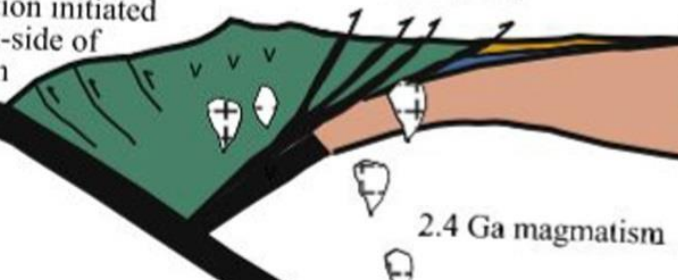

\section{$2.30-2.20 \mathrm{Ga}$}
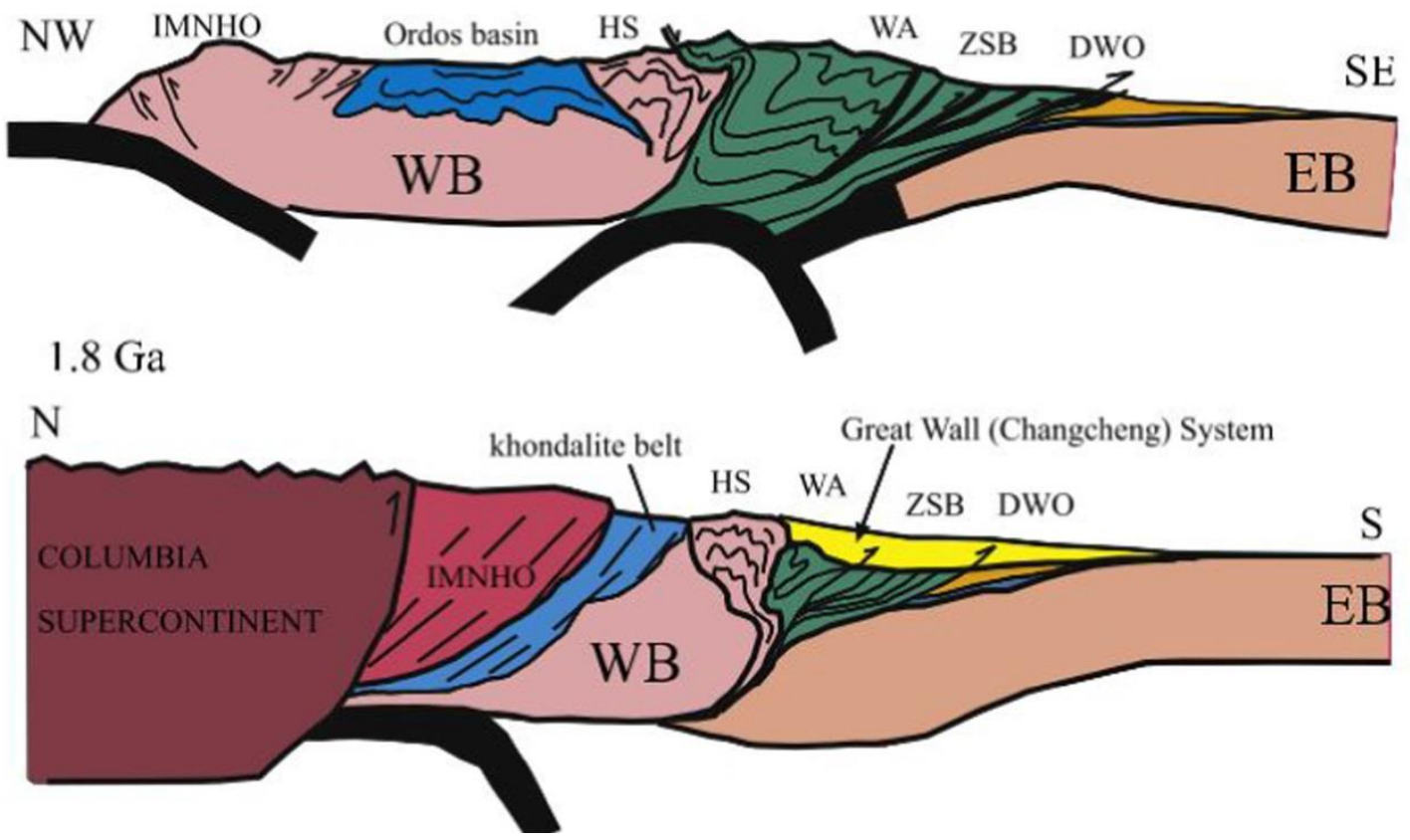

Figure 2.2 Possible model for the formation of the North China Craton and the Wutai complex taking into account recent seismic evidence for westward dipping paleosubduction zones. From Kusky (2011). 
that the collision occurred in the Archean between 2.5 and 2.2 Ga. Additionally, there was another major collisional event that occurred around 1.8 Ga involving the Columbia Supercontinental collision with the NCC from the north. Kusky's (2011) model showing mostly westward subduction is supported by seismic imaging done by Zheng et al. (2010), though Zhao contends that the orientation of the seismic profile was not ideal for imaging the TNCO.

\section{B. Precambrian Lithology of the Study Area}

The North Wutaishan Fault (NWTSF) is located in the COB (TNCO) of the NCC, along the northern edge of the Wutai Complex, marking the southern border of the Daixian Basin (Figure2.3)(Kusky, 2011; Kusky et al., 2007; Kusky and Li, 2003; Zhao et al., 2007). The Wutai Complex is composed of the Lower (Shizui (amphibole)), Middle (Taihuai (greenschist)) and Upper (Gaofan (subgreenshist)) subgroups of the Wutai Group (Kusky and Li, 2003). The Wutai Complex also contains Late Archean granitoids (Kröner et al., 2005). Recently, Zhao et al. (2007) suggest that, considering SHRIMP U$\mathrm{Pb}$ zircon ages and field observations, the Wutai Group formed as an assemblage of volcano-sedimentary rocks rather than as separate stratigraphic units between 2.53 and 2.515 Ga. The lithology of this group is closely related to those found in modern volcanic arcs (Zhao et al., 2007).

Bedrock close to the study area consists of rocks from the Shizui amphibole subgroup (Kröner et al., 2005). This group contains amphibolites, banded iron formation (BIF), biotite-rich schists (some including kyanite), dacite as well as some minor carbonates. 


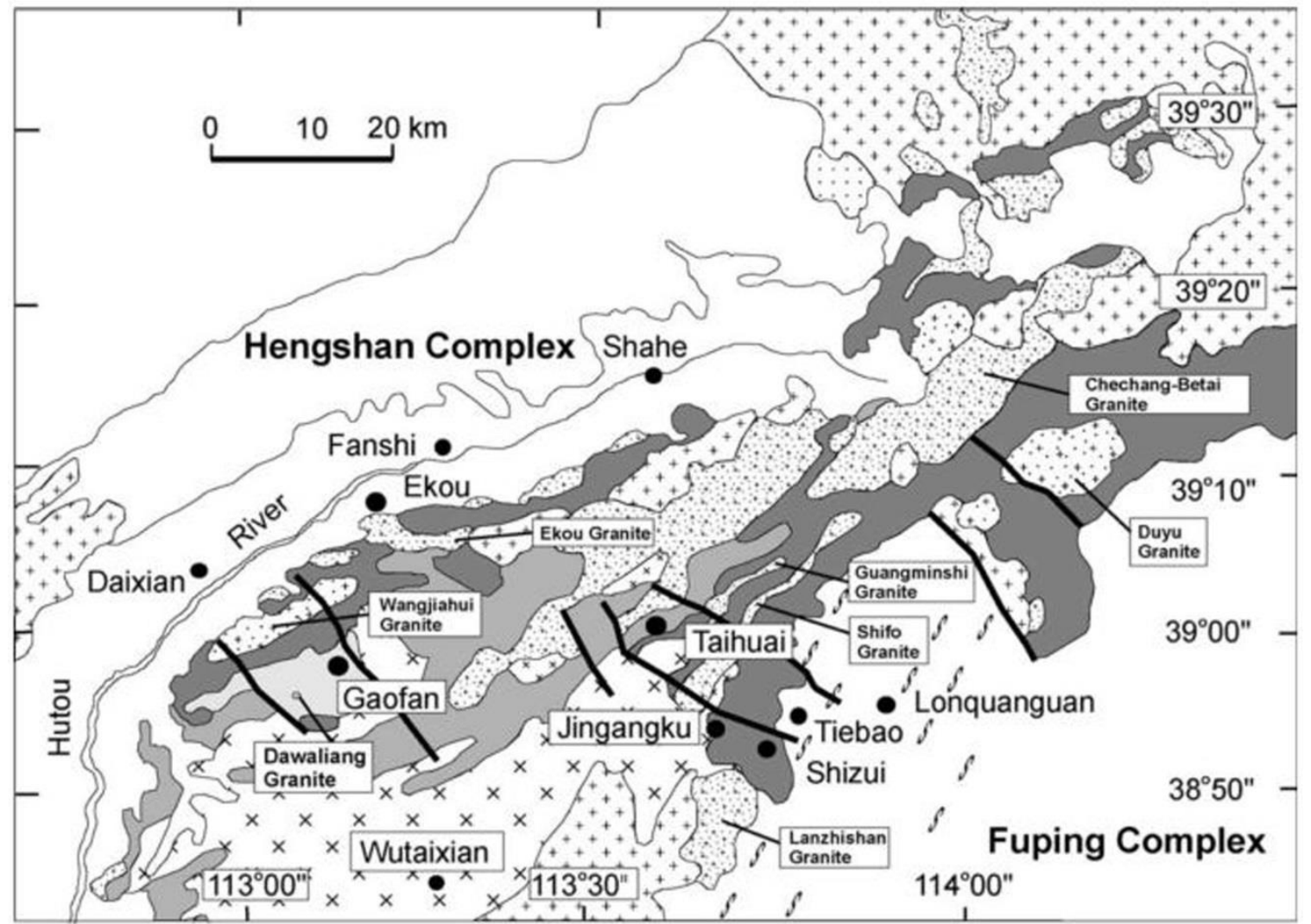

\begin{tabular}{|c|c|}
\hline & Quaternary/Cenozoic cover \\
\hline+ & Mesozoic/Proterozoic cover \\
\hline$\because::$ & Mesozoic granitoids \\
\hline & Proterozoic granitoids \\
\hline & Major Faults \\
\hline 5 & Major Shears \\
\hline
\end{tabular}
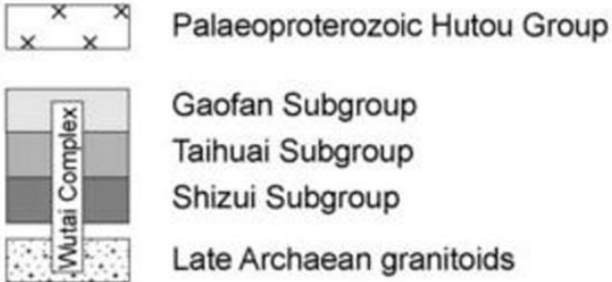

Gaofan Subgroup

Taihuai Subgroup

Shizui Subgroup

Late Archaean granitoids

Figure 2.3 Simplified regional geology of the Hengshan-Wutai-Fuping area of the North China Craton. The red box denotes the extent of the study area. Modified from Kröner et al. (2005). 


\section{Formation of the Shanxi Graben System}

Beginning in the Middle Jurassic and continuing on into the Cretaceous, the Yanshan Orogeny caused the region of the present-day Shanxi Graben System to experienced NNE - SSW folding and the creation of left lateral transpressional fault belts (Li et al., 1998). During the Paleocene, basaltic eruptions to the north accompanied regional uplift ( $\mathrm{Li}$ et al., 1998). Weathering during a stable period in the Miocene left a layer of reddish clay across the Shanxi Highlands (Li et al., 1998).

The majority of basin subsidence and uplift of the surrounding mountains occurred during the mid to late Pliocene (He et al., 2003; Li et al., 1998; Zhang et al., 1998). During this time lakes formed in the basins, which subsequently dried out in the late Pliocene when subsidence slowed and the climate became drier. Basins were then filled with red and sandy clays as well as gravels. Subsidence increased with the start of the quaternary, leading to the development of large lakes until the late Pleistocene ( $\mathrm{Li}$ et al., 1998).

The Shanxi Graben System region saw uplift again with a period of intense tectonic activity in the mid to late Pleistocene ( $\mathrm{Li}$ et al., 1998). In addition to volcanic activity that occurred in the region, lakeshores were uplifted (Li et al., 1998). Rivers, such as the Hutou River which runs through the Daixian Basin, experienced intense downcutting, draining the lakes that had developed within the basins (Li et al., 1998). It is possible that the climate also dried out, assisting with the desiccation of the basins' lakes (Li et al., 1998).

Sediment thicknesses derived from shallow seismic profiles and borehole data show a range of sediment thicknesses throughout the Daixian Basin (Xu et al., 1993). 
Cenozoic sediments generally increase in maximum age and thickness southward in the Shanxi Graben System, whereas Neogene sediments within the basins range from 600 to 2000 meters thick, with sediments being older and thicker in the south rather than the north (Zhang et al., 1998). This suggests extension likely propagated from the southwest to the northeast (Figure 2.4)(Li et al., 1998; Xu et al., 1993; Zhang et al., 1998). The depth of the Moho increases from the south to the north, supporting a southwest to northeast basin extension: $34-36 \mathrm{~km}$ beneath the Weihe Basin to the south, $36-38 \mathrm{~km}$ under the Northern Shanxi Grabens (Zhang et al, 1998).

Pliocene sediments consist of mostly reddish clays ( $\mathrm{Li}$ et al., 1998; Zhang et al., 1998) while Miocene sediments were not preserved due to uplift and erosion (Xu et al., 1993). Mostly quaternary fluviolacustrine deposits are found toward the center of the basins, whereas younger aeolian loess (mid Pleistocene and above) intermixed with sandy paleosols are found along the basin edges (Li et al., 1998; Zhang et al., 1998).

Different hypotheses have been proposed to explain the cause of crustal extension of the Shanxi Graben System. Through an analysis of fault kinematics observed from SPOT aerial imagery and earthquake focal mechanisms, Zhang et al. (1998) suggest that extrusional tectonics related to the collision of the India - Eurasia Plates is causing a counter clockwise rotation of the Ordos, Taihangshan and North China Plain continental fragments prompting an opening of rift valleys surrounding the Ordos Plateau.

Li et al. (1998) note Bouguer gravity anomalies under the basins, high thermal anomalies and a 2-3 km upwarping of the upper mantle under the Shanxi Graben System with Pleistocene volcanic eruptions as supporting evidence for these geophysical observations. Additionally, the left-stepping geometry of the basins and right lateral 


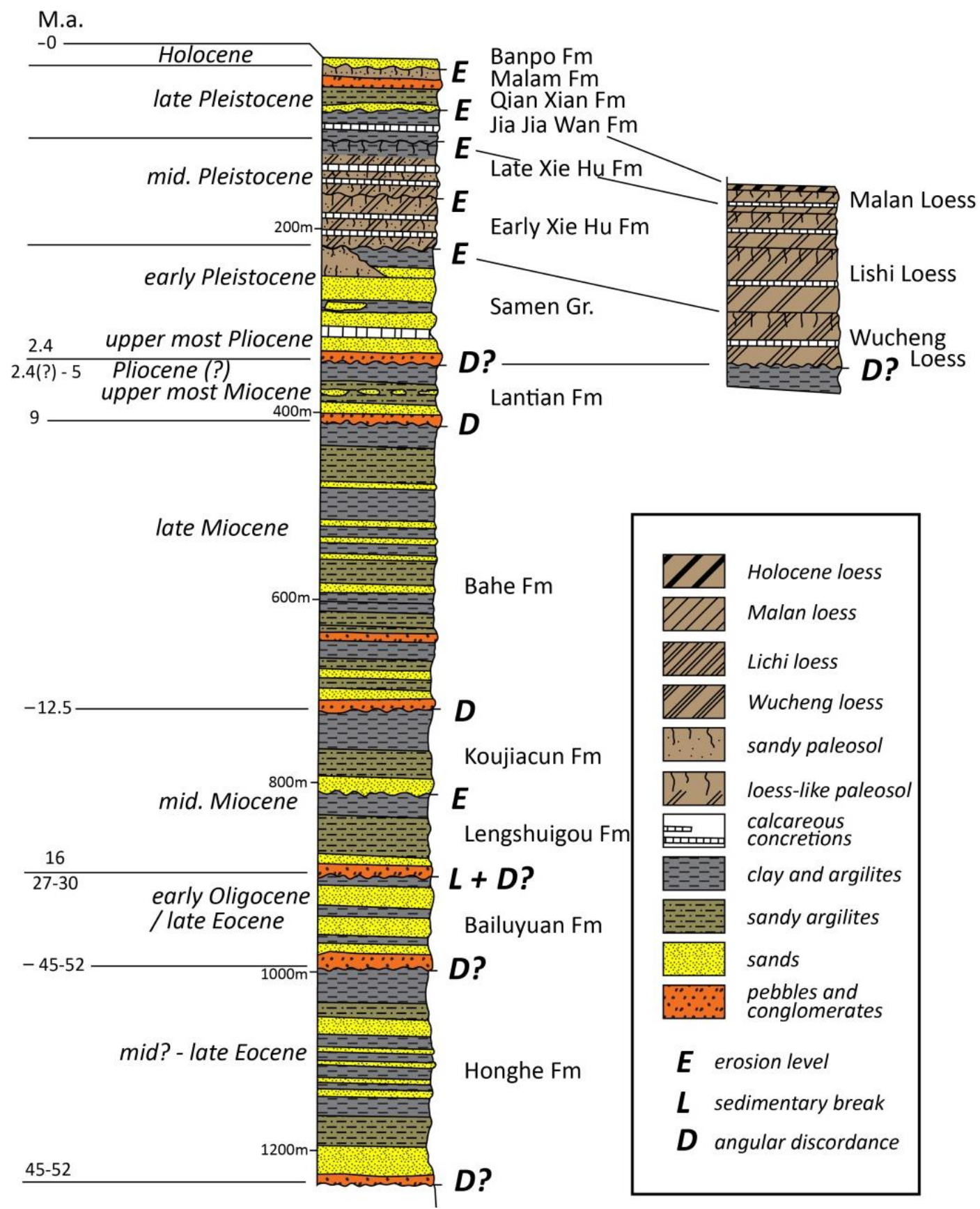

Figure 2.4 Simplified stratigraphic column of the Cenozoic stratigraphic units in the Weihe basin at the southern margin of the Shanxi Graben System. Modified from Zhang et al. (1998). 
movement along faults in the middle of the system could be explained by right lateral sheer resulting from the compressional interaction between the collision of the India Eurasia plates from the southwest as well as the Pacific plate from the north-northeast. This compression and shearing combined with the upwarping of the upper mantle could have resulted in the uplift and formation of the Shanxi Graben System.

Liu et al. 2004 used P-wave seismic tomography to test the theory that the collision of the Indian and Eurasian Plates caused a lateral extrusion of mantle asthenosphere underneath eastern China. This lateral mantle extrusion could help explain rifting along the Shanxi Graben System by identifying the cause of mantle upwarping that has been identified in the region (Li et al., 1998).

\section{III.Active Tectonics in the Shanxi Graben System}

\section{A. The Shanxi Region}

Past studies have attempted to quantify current extension across the graben system using GPS measurements. Initial GPS measurements by Shen et al. (2000) and Wang (2003) showed around 3-4 mm/yr extension NW/SE across the system. Through an analysis of the data from Shen et al. (2000) as well as additional GPS measurements, He et al. (2003) reported no measureable extension the Shanxi Graben System within the uncertainties of their data (Figure 2.5). They suggest this could be due to time scale dependency of the data showing only interseismic deformation while the faults that bound the grabens are locked. The implication is that if there is extension it would be less than the uncertainties of their data: less than $1.5 \mathrm{~mm}$ per year.

Paleoseismic studies have further examined the long term crustal deformation and paleoseismicity of the Shanxi Graben System (Ding et al., 2010; Liu et al., 1991; Zhang 

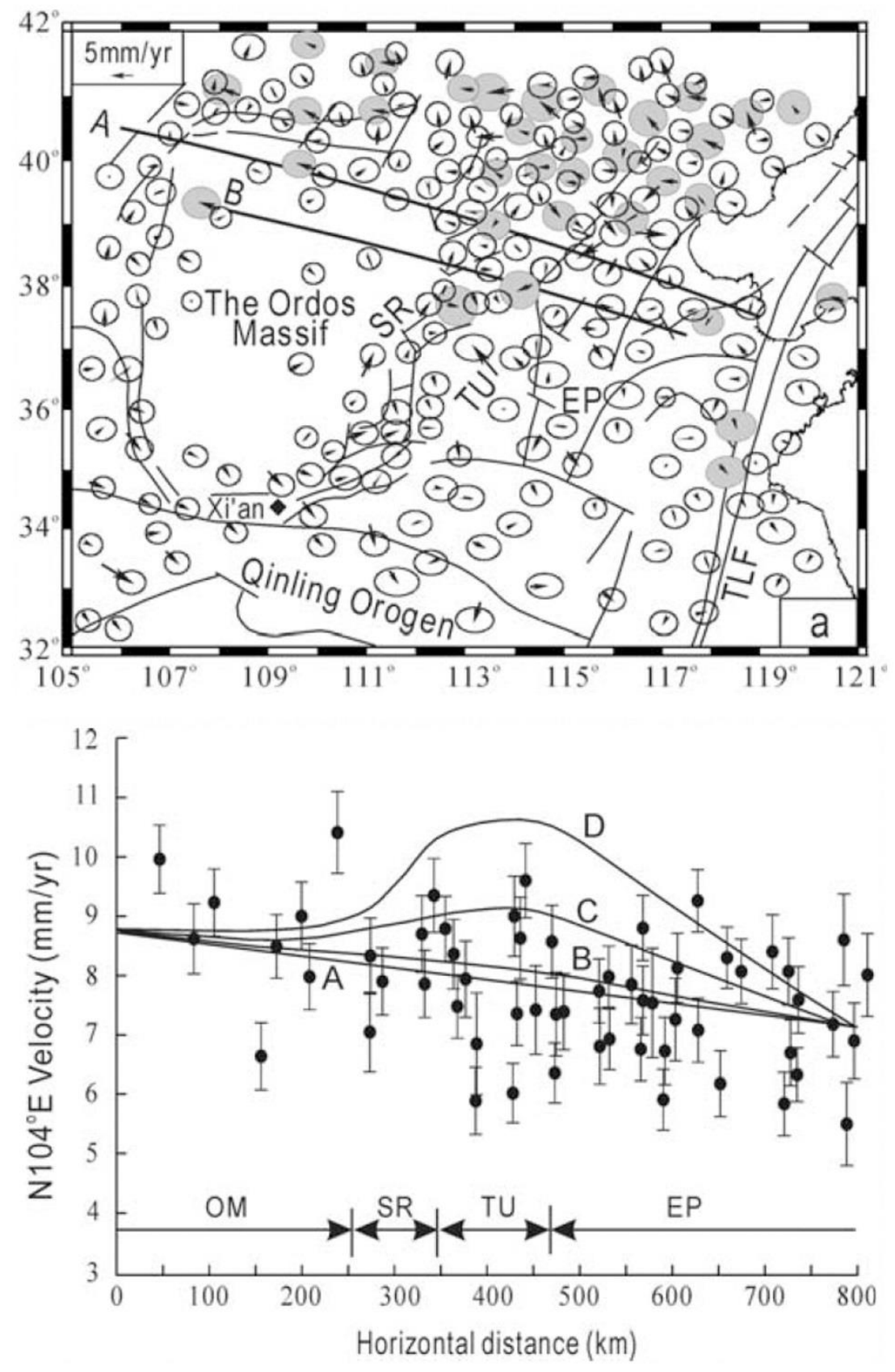

Figure 2.5 GPS velocities reported in the region surrounding the Shanxi Graben System. From He et al. (2003). 
et al., 2007; Zhang et al., 1998). Chinese historical records document $21 \mathrm{M} \geq 6$ earthquake events that have occurred in the Shanxi Graben Area (Figure 2.6)(Xu et al., 1993). These include four $\mathrm{M} \geq 7$ earthquakes such as the $\mathrm{M}=81303$ Hongdong Earthquake and the M=7.5 Linfen earthquake in 1695 (Liu et al., 2007; Xu et al., 1993). Zhang et al. (1998) used SPOT aerial imagery to map right lateral stream offsets along strike slip faults between the NE/SW trending basins. Thirty-three years of seismicity data were used by Yi et al. (2004) to calculate strain accumulation in the lower portion of the Shanxi Graben System. Earthquake risk potential was then determined for different segments of the graben system, listing the Houma and Jiexiu-Fenyang segments as high risk.

\section{B. The Xinding Basin}

The Xinding basin is located in the northern portion of the Shanxi Provence. It is composed of three sub-basins: Daixian, Yuanping and Dingxiang (Figure 1.2)(Xu et al., 1993). This study is focused on the North Wutaishan Fault (NWTSF), specifically the area near Nanyukou Village at the northeastern end of the Daixian basin. The NWTSF consists of 20 discontinuous fault segments spanning a distance of $\sim 85 \mathrm{~km}$ along the southern edge of the basin (Ding et al., 2010; Xu et al., 1993). The NWTSF is a normal fault with a general strike of $\sim 60^{\circ}$, dipping between 50 and 70 degrees to the northnorthwest (Ding et al., 2010; Xu et al., 1993). Borehole data show the maximum age and thickness of sediments increases to the southwest within the basin with sediments near Shahe (Figure 2.3) having a thickness of only 111 meters (Xu et al., 1993). This suggests that the Daixian basin developed from the southwest to the northeast.

In the Xinding basin, three $M \geq 7$ earthquakes have occurred since 512 A.D.: the $\mathrm{M}=7.5$ Daixian earthquake in 512, the $\mathrm{M}=7.25$ Xinxian-Dingxian earthquake in 1038 and 


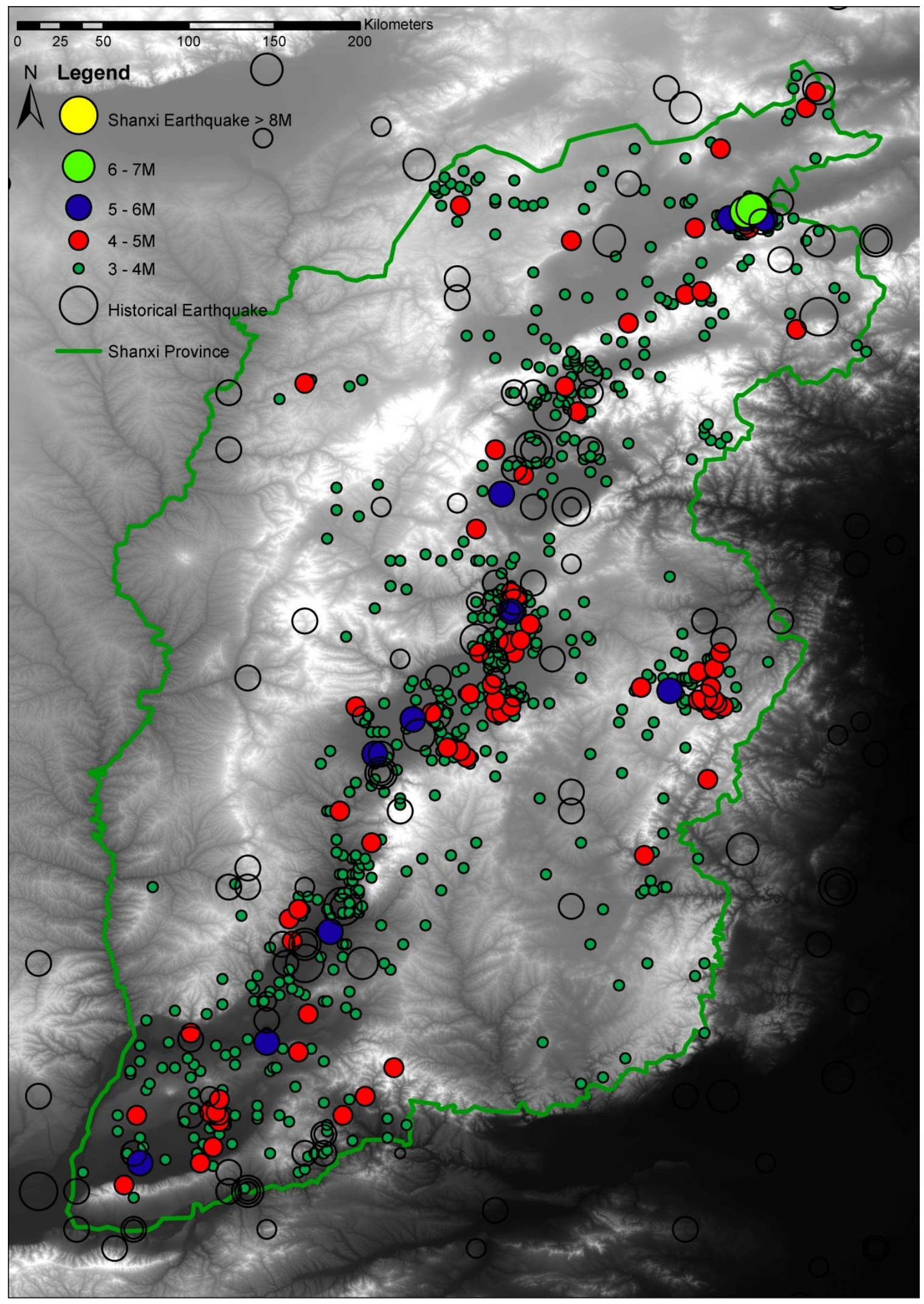

Figure 2.6 Historical and recent seismicity for the Shanxi Graben System. 
the $M=7$ Yuanping earthquake in 1683 ( $\mathrm{Xu}$ et al., 1993). The 512 A.D. Daixian earthquake is thought to be the most recent major earthquake event that occurred on the NWTSF. Surface ruptures and fault scarp displacements between 2 to 3.1 meters on the middle portion of the NWTSF have been linked to the Daixian event (Ding et al., 2010; Liu et al., 1991).

The last earthquake event along the NWTSF has been bracketed by faulted and unfaulted fluvial terraces near Liyu Village dated at $2700 \pm 210$ and $1640 \pm 112$ years BP (Liu et al., 1991). These dates are consistent with the 512 A.D. Daixian earthquake, since there have been no other earthquakes of large enough magnitude to cause surface ruptures in the past 2700 years (Liu et al., 1991; Xu et al., 1993). Additionally, Liu et al. (1991) reported two other paleoearthquake events between 2700 and $7600 \mathrm{BP}$ and an approximate earthquake recurrence interval for the NWTSF of 2300 years (Liu et al., 1991; Xu et al., 1993).

Recent work by Ding et al. (2010) identifies six paleoearthquake events in the last 7600 years with an average recurrence interval of 1400 years. Timing of these events was based off the dating of colluvial wedges and alluvial cone deposits from two trench sites from the eastern portion of the NWTSF just northeast of Nanyukou (Table 2.1). The most recent event identified is thought to be the 512 A.D. Daixian earthquake. This would mean the surface rupture of that event reached at least as far northeast as Nanyukou village, though further study in this area is required to support this find.

Average vertical slip rates determined from a series of trenches dug along the NWTSF by Liu et al. (1991) show $\sim 0.47-0.64 \mathrm{~mm} / \mathrm{yr}$ for the western section of the NWTSF and $\sim 0.82-1.67 \mathrm{~mm} / \mathrm{yr}$ for the eastern section for an average of $\sim 1.0 \mathrm{~mm} / \mathrm{yr}$ 


\begin{tabular}{cccc}
\hline Number & $\begin{array}{c}\text { Time window of the } \\
\text { events ( a B. P. })\end{array}$ & $\begin{array}{c}\text { Estimate time of occurrence } \\
(\text { a B. P. })\end{array}$ & $\begin{array}{c}\text { Recurrence intervals } \\
(\text { a })\end{array}$ \\
\hline$D_{1}$ & Before 7600 & Before 7600 & - \\
$D_{2}$ & $7600 \sim 6700$ & 7150 & - \\
$D_{3}\left(A_{1}\right)$ & $5321 \sim 5575$ & 5448 & 1700 \\
$A_{2}$ & $4400 \sim 5400$ & 4900 & 550 \\
$A_{3}$ & $4200 \sim 4400$ & 4300 & 500 \\
$D_{4}\left(A_{4}\right)$ & Since 1600 & $512 ?$ & 2800 \\
\hline
\end{tabular}

Table 2.1 The last 6 earthquake events on the North Wutaishan Fault as recorded by Ding et al. (2010) from trench sites at the Northeastern Edge of the NWTSF. Dates are collected from interpreted colluvial wedges (D1-4) and Alluvial deposites (A1-3). From Ding et al. (2010). 
vertical slip rate for both (Xu et al., 1993). Adjacent to our study area, Zhang et al. (2007) examined Quaternary river terraces on the NWTSF and determined that the area had experienced six rapid uplift events since the beginning of the Quaternary. The last four of these events are thought to have begun 1.2, 0.6, 0.13 and 0.02 Ma B.P. 


\section{Chapter 3: Geomorphology of the Study Area}

Observation of the geomorphology surrounding the paleoseismic trench sites helps to better understand the stratigraphy within the trench itself. Identification and mapping of geomorphic features also allows for more accurate trench placement in order to obtain the target result from the trench, such as excavating in a relatively undisturbed location most likely to have recorded and preserved the last faulting event.

\section{Fault Trace Mapping and Trench Site Selection}

Mapping of the NWTSF was conducted using Google Earth Imagery where available as well as orthorectified Cartosat imagery generated using photogrammetry software (Geomatica OrthoEngine)(Figures 3.1 and 3.2). Fault scarps and triangular facets were clearly visible on all the imagery despite extensive agricultural terracing in the region. The fault trace is broken up into multiple segments due to alteration of the fault scarp by erosion or, in some cases, human modification. Some segments were completely removed by rivers and drainages flowing northwest out of the Wutai Mountains such as the Yangyan River adjacent to the study area.

DEMs of the Daixian basin were generated at 5-meter-pixel resolution from the Cartosat imagery to assist in the tracing of fault derived geomorphic features such as fault scarps and triangular facets. The DEMs were also necessary for the orthorectification of the Cartosat imagery. Ground Control Points (GCPs) used in the photogrammetry process were referenced from Google Earth where imagery was of comparable pixel resolution to the Cartosat Imagery. Elevation values for the GCPs were extracted from a 90 meter resolution Shuttle Radar Topography Mission (SRTM) dataset.

The raw DEMs were cleaned using workflows created in Esri ArcGIS. The 


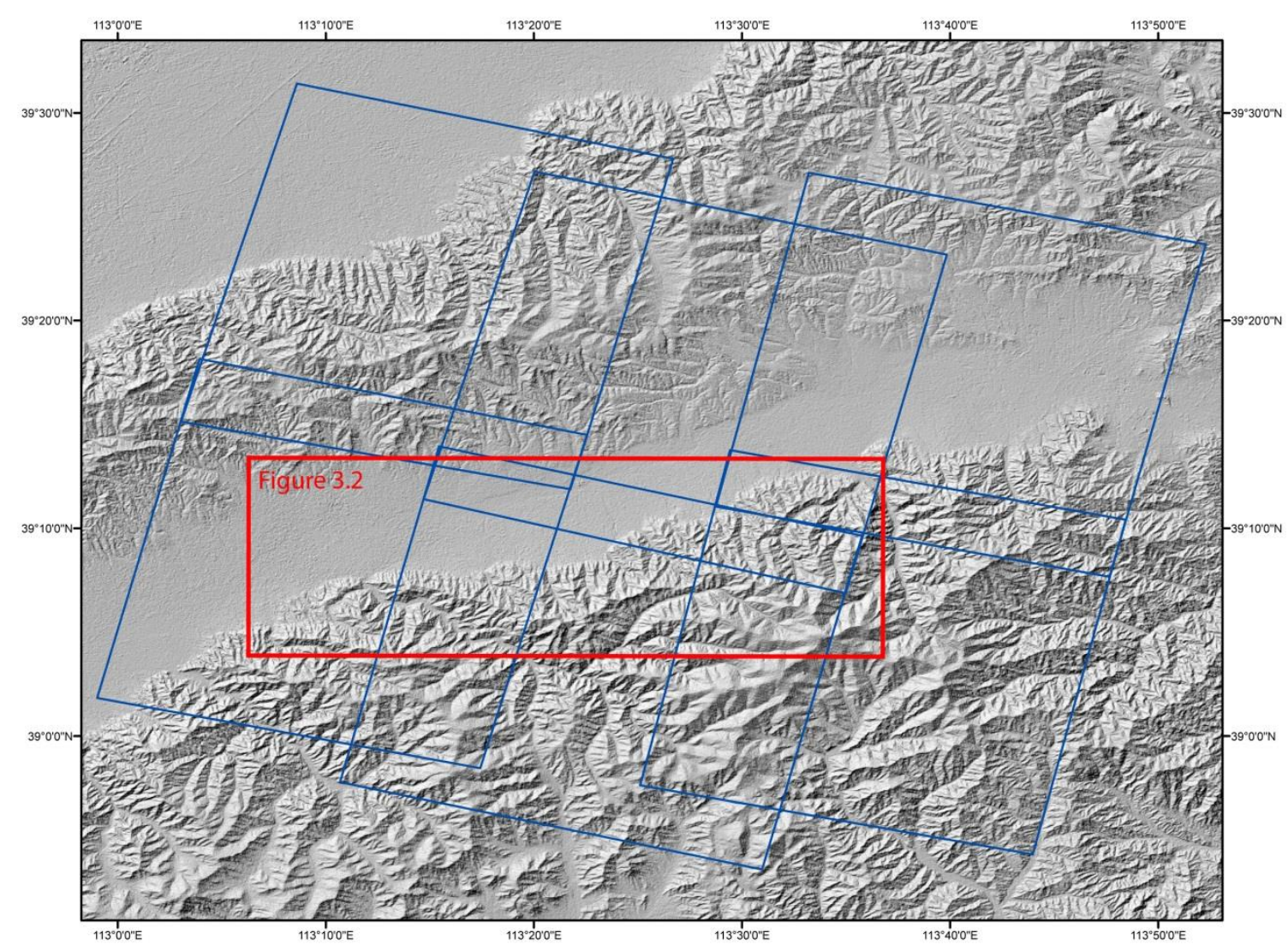

Figure 3.1 A DEM of the Daixian Basin of North China. Outlined are the footprints for the Cartosat Imagery used to make 5-meter-pixel DEMs of the area. 


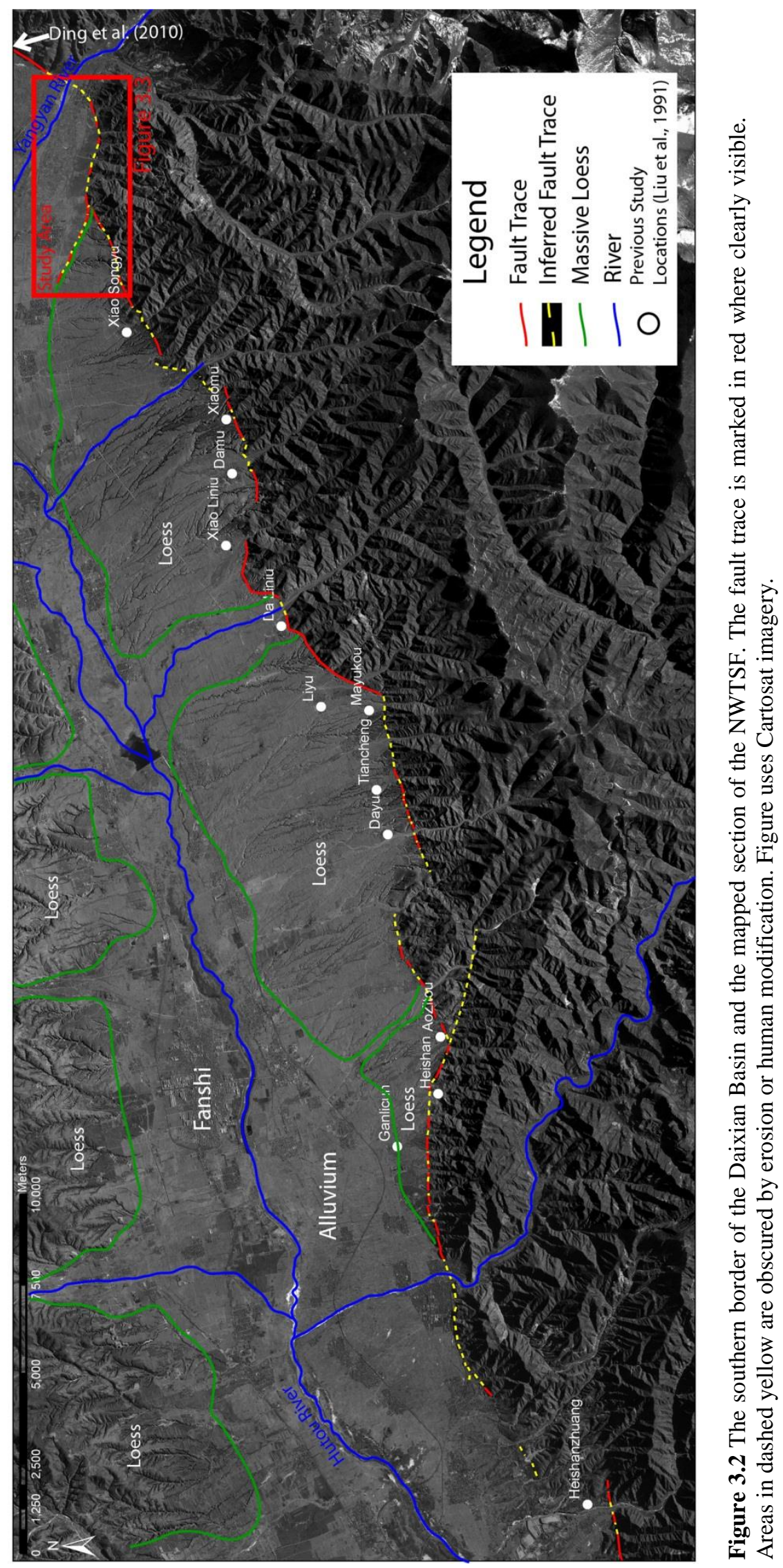


Cartosat imagery contained deep shadows in areas with higher topography due to rapid elevation changes and steep hillslopes. This resulted in the generation of some artifacts and data loss within the 5 meter DEMs. Significant artifacts in the form of large elevation errors within the DEMs were removed by comparing the generated DEMs with a 30 meter resolution Aster Global Digital Elevation Model Version 2 (GDEM V2) ${ }^{1}$ dataset. Positive and negative thresholds for the difference between the two DEMs were set, significant artifacts were identified, and a slightly expanded area around the artifacts was removed. These holes in the DEM were then filled using a natural neighbor interpolation. South of the town of Shahe the main fault bifurcates with a short branch striking roughly $296^{\circ} \mathrm{NW}$, displacing alluvium and massive loess deposits, while the main fault continues to the southwest, bounding the mountain front (Figure 3.3). Along the northern branch and to the east of the split, large alluvial fans were deposited with their apexes at the fault scarp and remain, for the moment, relatively unmodified by human development. These large exposed features adjacent to one another are unique across the NWTSF. Large open pit iron mines are present in the hills south of the fault, though there has not been a large observed increase in sedimentation at the mountain front directly linked to these operations.

Multiple sites suitable for paleoseismic trenching were identified from the imagery based on the following criteria: The trench must intersect a fault; The trench must be in a location where the presence of datable material in the trench wall is likely; It must be in an area that has a suitable influx of sediment, enough to accumulate identifiable stratigraphy after an earthquake event but not so much that it obscures any evidence of the event (i.e. next to the mouth of a small drainage area as opposed to a

\footnotetext{
${ }^{1}$ ASTER GDEM is a product of METI and NASA
} 


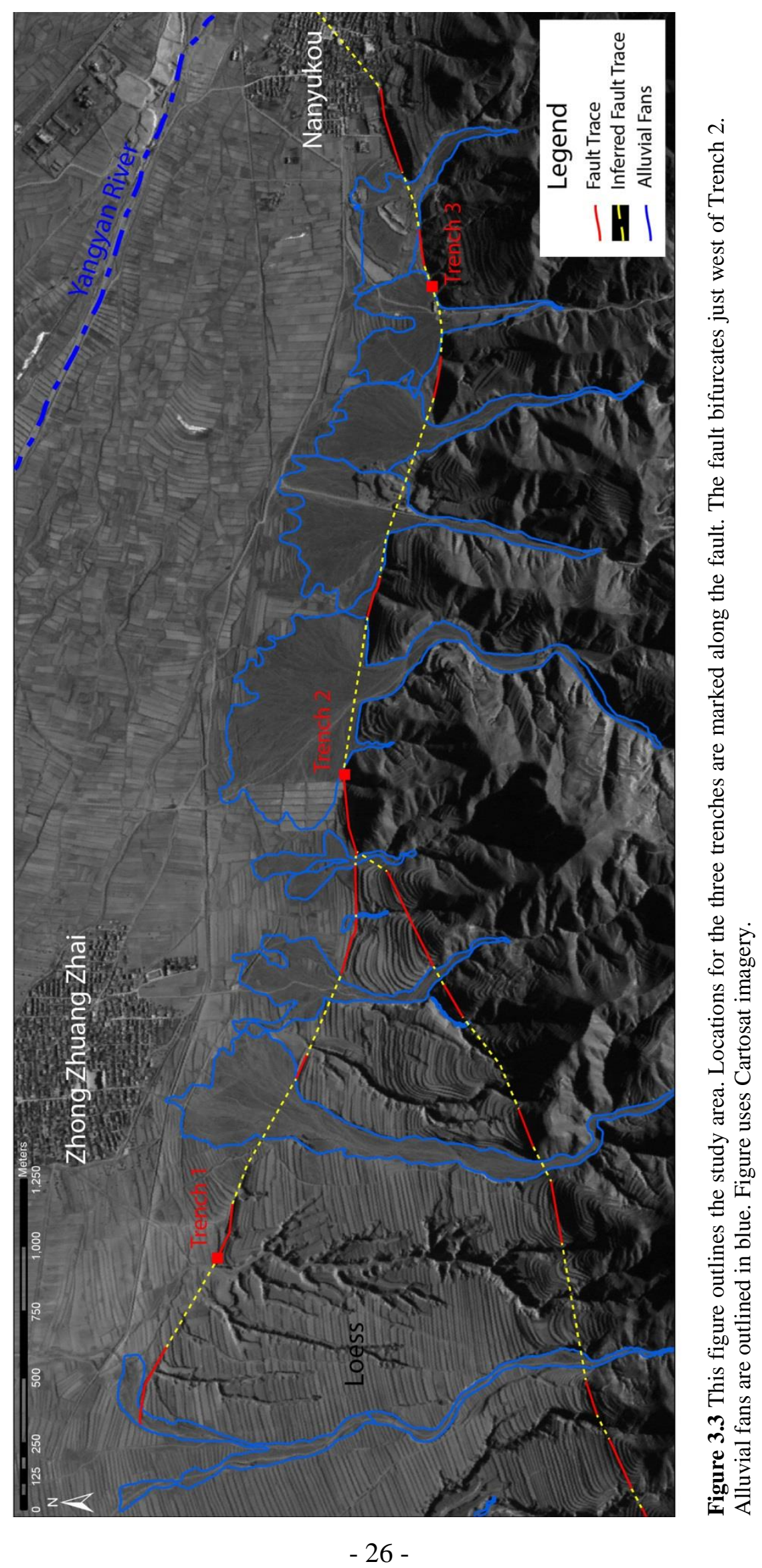


large one, where the trench wall is all one bed of gravel). The trench must also be in a location where erosion is minimal in order to preserve the record of earthquake events. For this study, sites were also selected by their potential to preserve evidence of the last earthquake event on this fault.

Three trenches were excavated along the NWTSF, south of Shahe, between the villages of Zhong Zhuang Zhai to the west and Nanyukou to the east. The first trench (Trench 1, ZZZ) was excavated in late July of 2011 just southwest of Zhong Zuang Zhai village. The trench was located on the short northern branch off the NWTSF west of the place of the bifurcation (Figure 3.4). A large drainage valley that has cut through thick beds of loess and gravels empties into the basin just a few meters west of the trench's location, close enough that the trench would not be starved of sediment yet far enough away that it wouldn't be completely filled with gravel, which would make it difficult to delineate any stratigraphic layers.

The second trench (Trench 2, NBT) was excavated in July of 2012. Located just east of the bifurcation on the main NWTSF, the site was located just west of a small drainage area cut into the bedrock on the south side of the fault (Figure 3.5). A large alluvial fan empties into the basin to the east and extends west across the mouth of the drainage where Trench 2 is located.

The third trench (Trench 3, NST) was also excavated in July of 2012. This trench is located to the east of Trench 2 on the main branch of the NWTSF, next to a small drainage just west of Nanyukou village (Figure 3.6). The site was exposed due to the terracing of a large alluvial fan for a local tree farm and was discovered while we were walking the fault trace within the study area. The exposure showed offset stratigraphy 


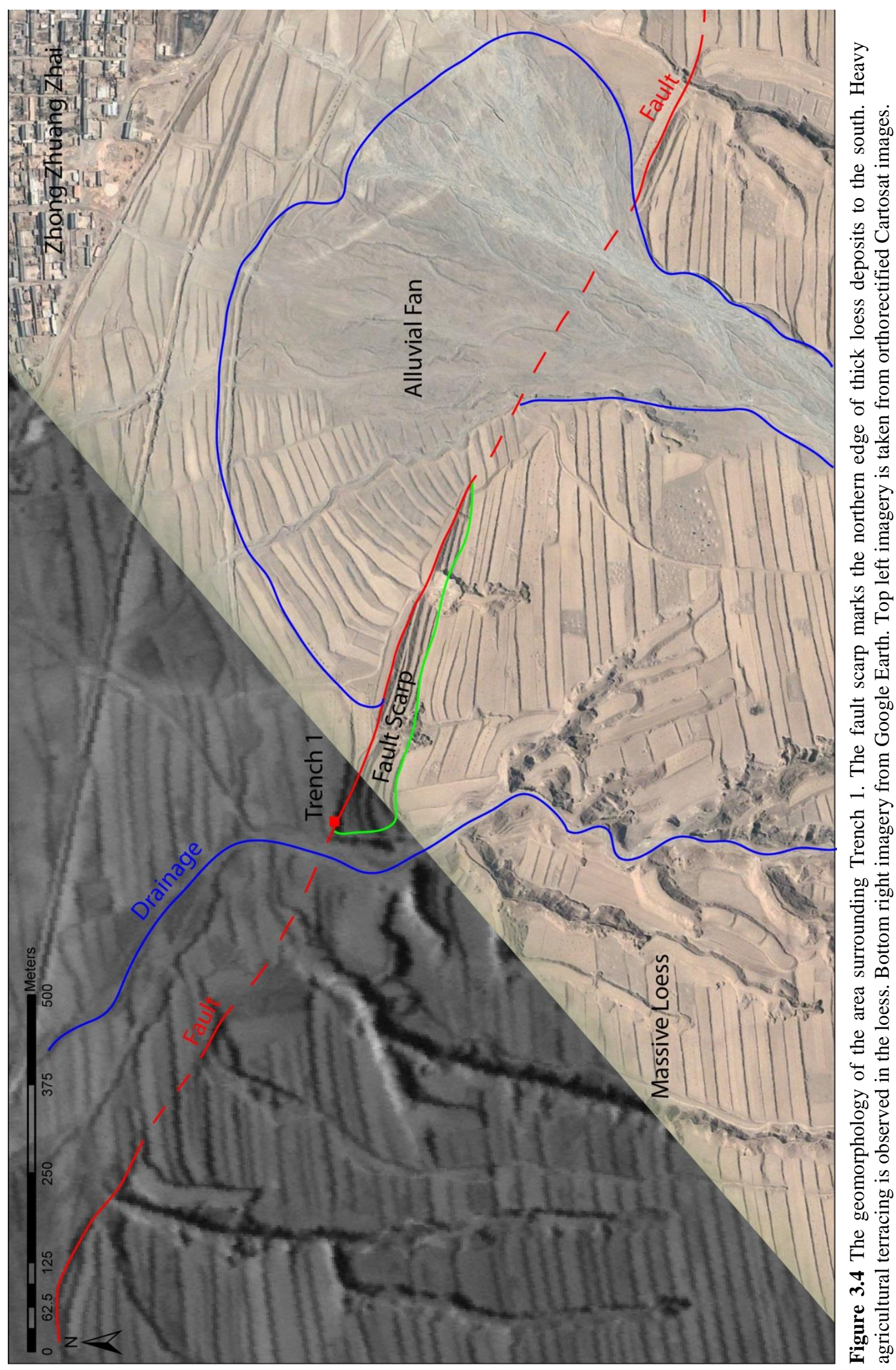




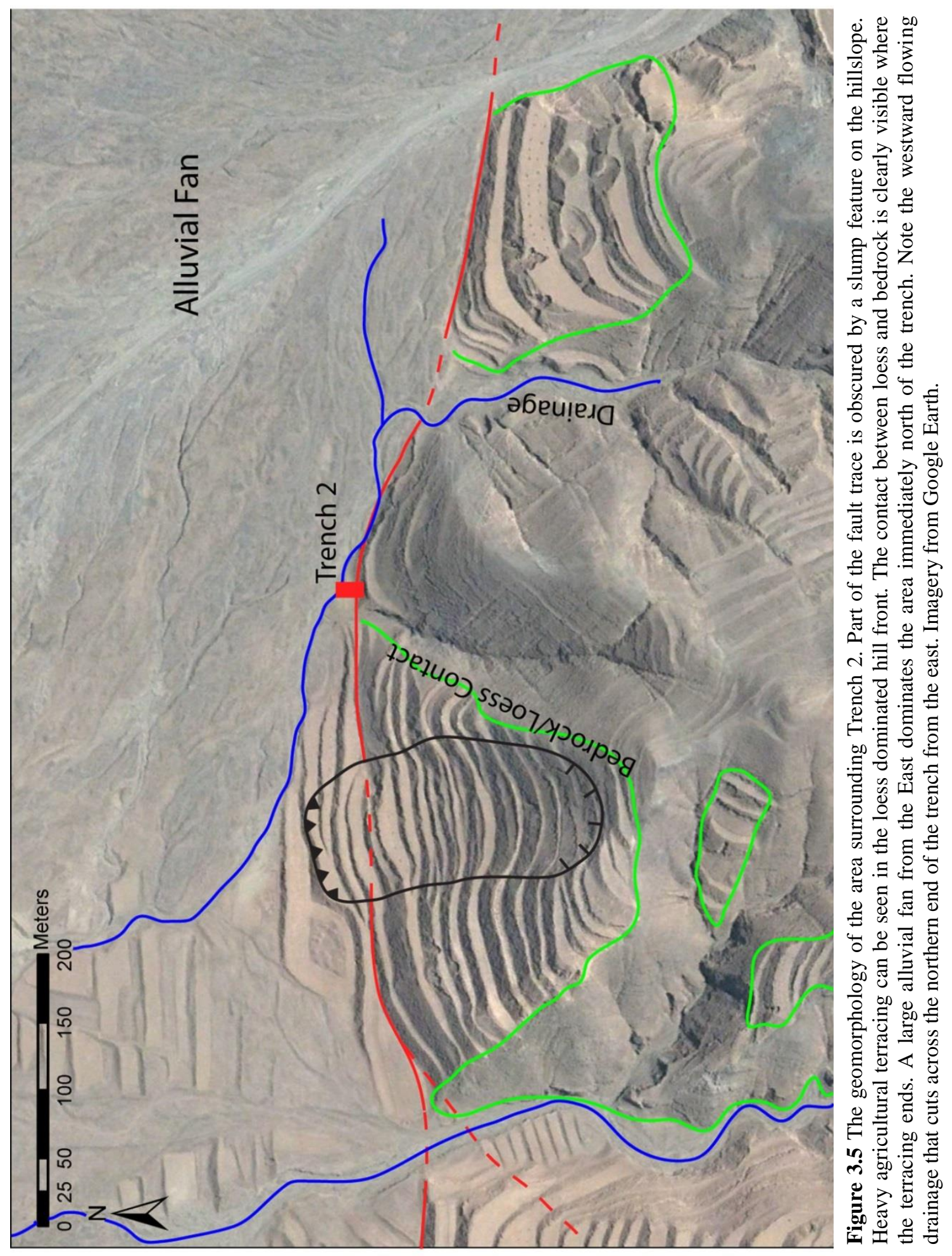




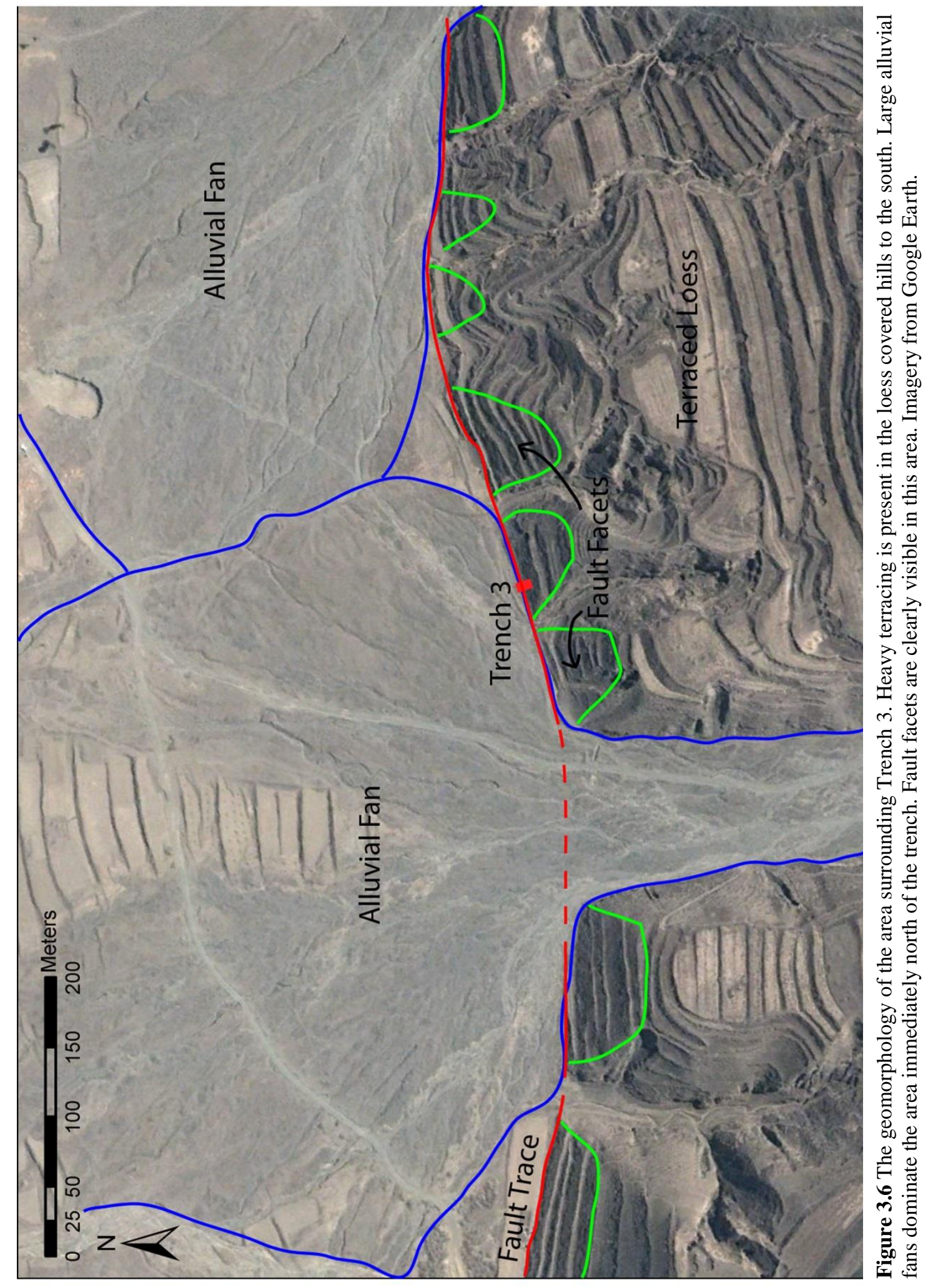


near the original ground surface so additional excavation was made.

\section{RTK GPS Survey Near Trench 2}

Two Real Time Kinematic (RTK) GPS surveys were made of the immediate area surrounding Trench 2, one before trenching and the other after. The objective of this survey was to map and measure small geomorphic features within the area. Survey points were taken manually using a 2 meter range pole along each break in slope, including the edges of each terraced surface with a survey line down the middle to increase point density (Figure 3.7). Points on the large, flat or nearly flat surfaces to the north of the fault scarp were gathered automatically at 1 point every second. This resulted in a total survey point spacing of roughly 2 meters apart, with a moderate amount of variation. DEMs were then interpolated from each survey using a Natural Neighbor interpolation method and combined to show the relation of the trench to the original surface (Figure $3.8)$.

Geomorphic features at the mouth of the drainage area showed evidence of two possible relict terrace surfaces on either side of the drainage (Figure 3.5). These features showed little anthropogenic modification and wrapped smoothly around the hillslope and into the drainage, suggesting they were natural surfaces. Profile lines were drawn across each surface with an orientation of $010^{\circ}$ orthogonal to the fault orientation for this segment of the NWTSF $\left(280^{\circ}\right)$. Original survey points within one meter of each profile line were projected onto their respective lines to generate scarp profiles, resulting in greater or less than two meter spacing between points on the profile (Figure 3.9).

The profile of the surface on the western side of the drainage (Profile 1) shows fault scarp with a vertical offset (throw) of $\sim 2.9$ meters. This surface (Q1) could represent 

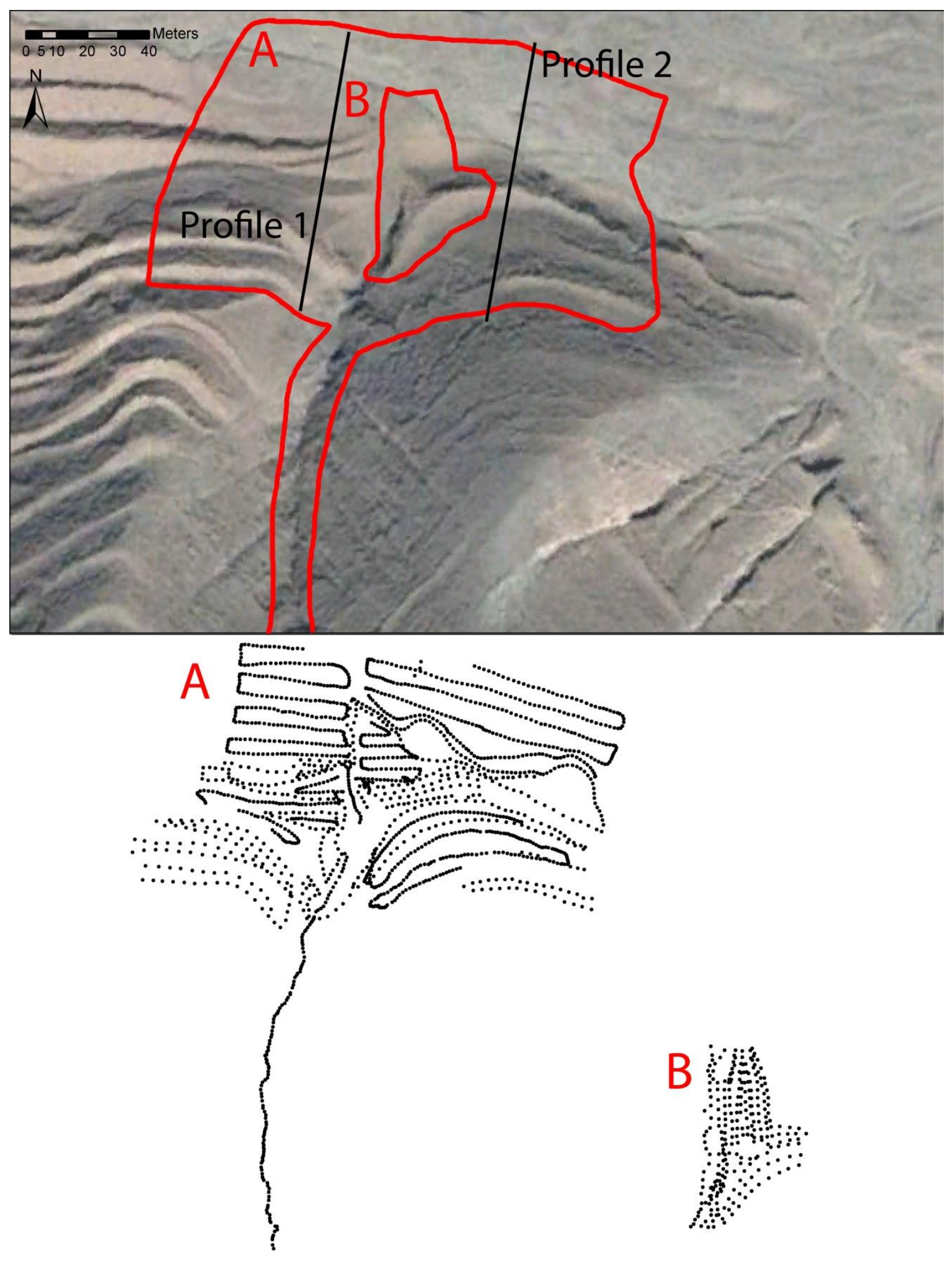

Figure 3.7 The two RTK GPS Surveys of the area surrounding Trench 2. The first survey (A) was conducted before the trench was excavated. The second survey (B) includes only areas modified by the excavation. Imagery from Google Earth. Profile lines 1 and 2 are marked in black (Upper Image) 


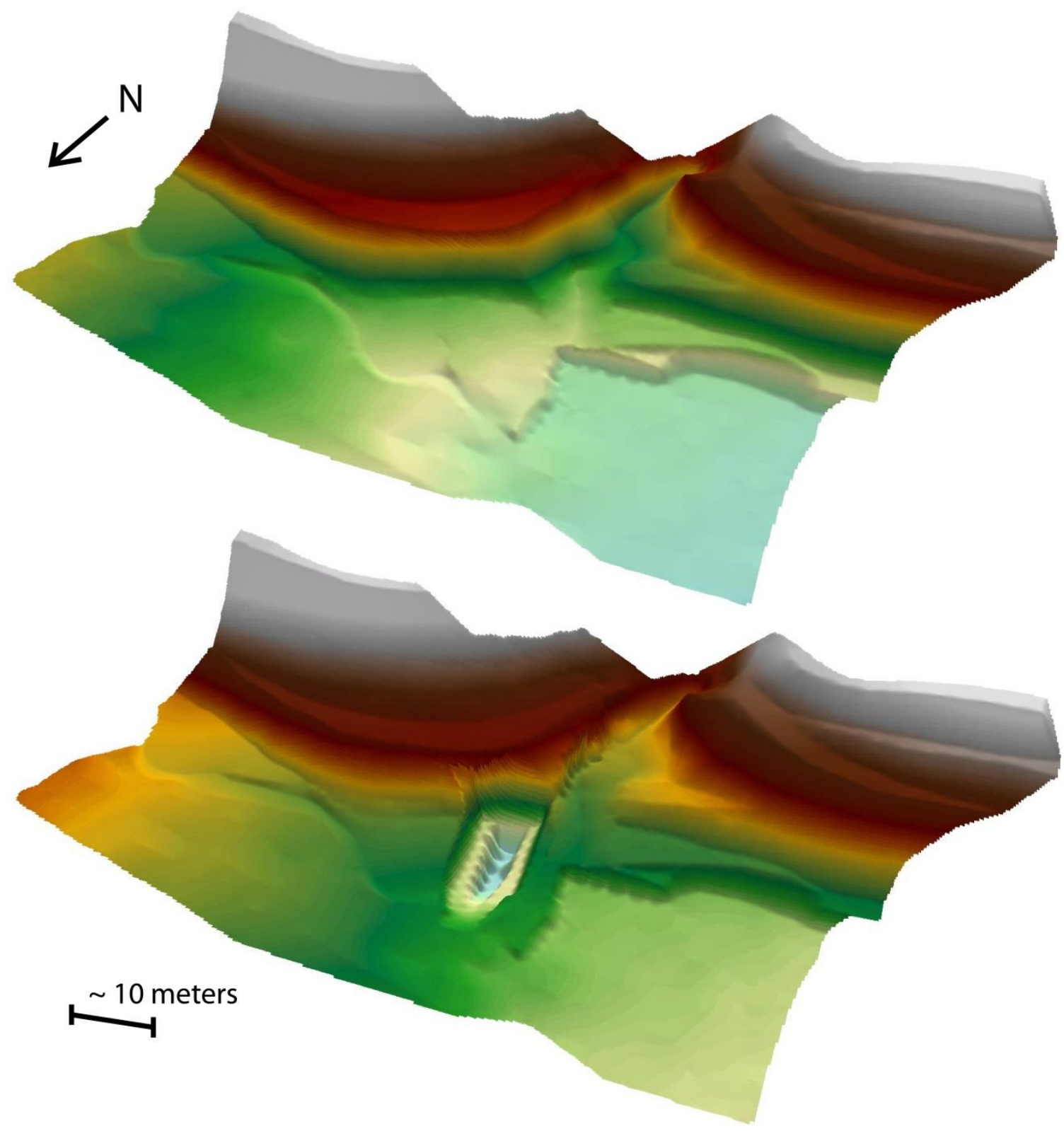

Figure 3.8 An interpolated DEM of the two RTK GPS surveys of the area surrounding Trench 2. The upper image represents the first survey only, while the lower image is a combination of the first and second survey and includes the paleoseismic trench (Trench 2). Models were generated using a Natural Neighbor technique in Esri ArcGIS, then displayed in ArcScene to obtain the images displayed in this figure. 


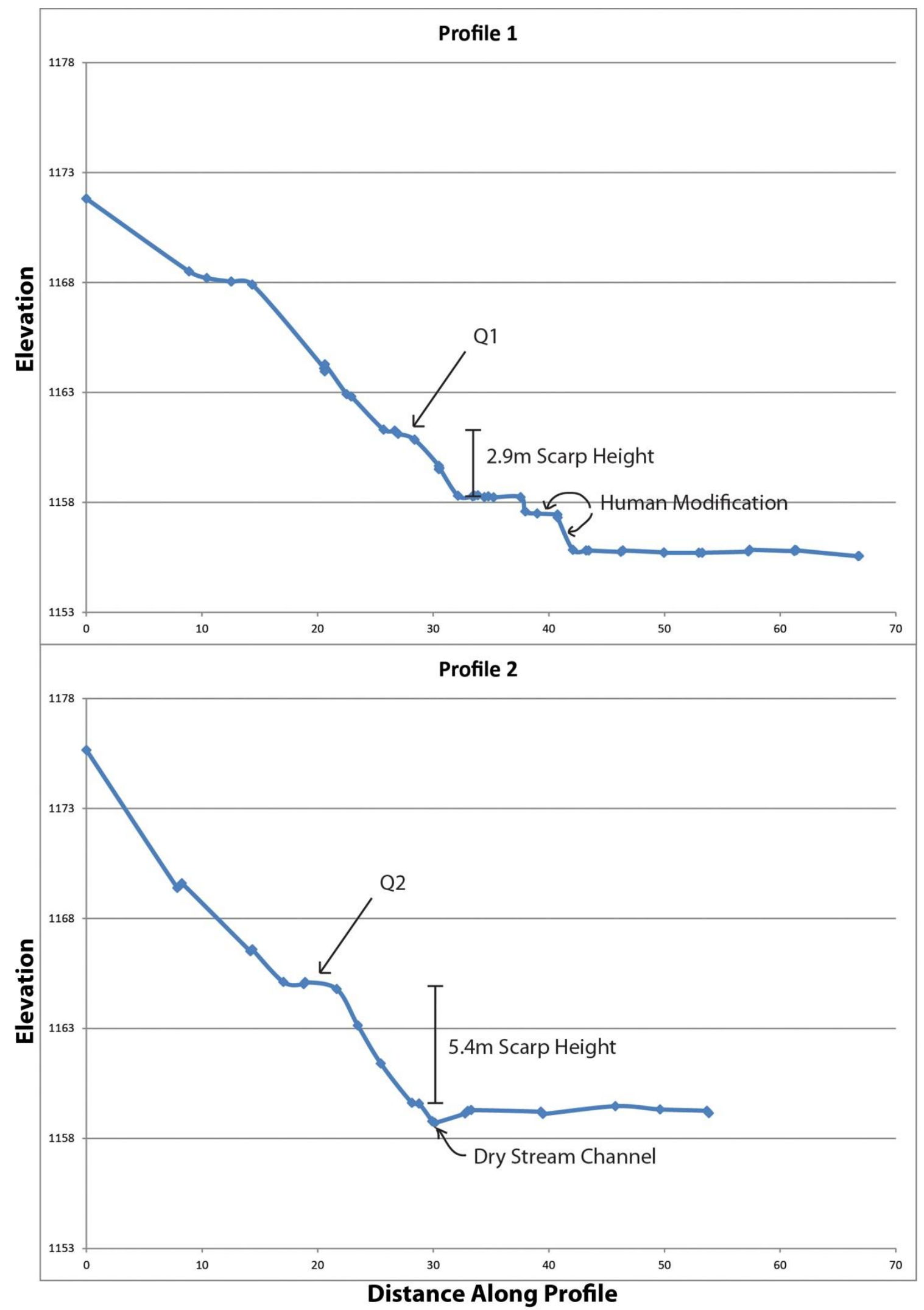

Figure 3.9 Profile plots across two potential relict fluvial terrace surfaces offset by the NWTSF. Plots were generated using Microsoft Excel. Vertical exaggeration is 1.9. 
a single event offset, possibly the last faulting event. The second profile (Profile 2) drawn across the surface on the eastern side of the drainage shows a fault scarp with a vertical offset of $\sim 5.4 \mathrm{~m}$. This surface (Q2) could be a composite scarp and represent multiple events, possibly the last two that have occurred on this fault. An estimation of the vertical offset of the penultimate event is obtained by differencing the two scarp heights, yielding a value of 2.5 meters.

The following formula from Wells and Coppersmith (1994):

$$
\mathrm{M}=6.78+0.65 * \log (\mathrm{AD})
$$

where $\mathrm{AD}$ is average displacement in meters and $\mathrm{M}$ is moment magnitude, was used to estimate earthquake magnitudes based on these scarp profiles. Vertical throw measured from each fault scarp was used as an approximation for average displacement. This is due to the steep angle shown in multiple faults within this trench $\left(70^{\circ}-90^{\circ}\right)$ and the uncertainty as to which fault the scarp represents. Additionally, the change in magnitude by using the slightly larger estimation for average displacement is minimal.

Assuming that the Q1 represents a single event scarp (and the last event) and the offset of 2.9 meters is representative of the average displacement along that fault then the magnitude for the last event is $\sim 7.1 \mathrm{M}$. Assuming that $\mathrm{Q} 2$ represents the last two events with the difference between the Q1 and Q2 scarp heights representing the penultimate event $(2.5 \mathrm{~m})$ then, using the above formula, that event had a magnitude of approximately $7.0-7.1 \mathrm{M}$.

The earthquake magnitudes calculated in this study are between those reported in previous paleoseismic studies of the NWTSF, suggesting that they are reasonable values for earthquakes typical along the NWTSF. Liu et al (1991) reported an earthquake that 
left a 2-3 meter high scarp between 2500 and 1600 years BP. This was based on measurements of offsets of a fluvial terrace observed in trench studies in the area. This displacement corresponds to an estimated earthquake magnitude of $7.0-7.1 \mathrm{M}$ using the Wells and Coppersmith (1994) formula written above. The 512 Daixian earthquake, the most recent earthquake event, was estimated to have a magnitude of $7.5 \mathrm{M}$ (He et al., 1993). 


\section{Chapter 4: Paleoseismic Trench Investigation}

\section{Trench Excavation and Preparation}

Various trenching styles and techniques for paleoseismic investigations have been developed since early investigations in 1979 (Figure 4.1)(see McCalpin (2009) and references therein). The size and type of trench used in a paleoseismic investigation is dictated by the type of fault, size of the fault scarp, the amount and type of material to be excavated and the nature of the information you are trying to get out of the trench. Dip slip faults tend to require deep trenches perpendicular to the fault trace in order to uncover multiple faulting events, while trenches along strike strip faults can be relatively shallow. Additional factors that may affect trench excavation include the equipment you have available, the amount of time you are able to spend on the trench and the material in which the trenches are being excavated.

The three trenches in this study were excavated in thick loess deposits with soils and gravels interspersed within each trench wall. Trench 1, excavated in July 2011, was approximately 7.5 meters deep with sloped walls and a 1-1.5 meter bench 4 meters down on the west side of the trench. Trench 2, excavated in August 2012, is approximately 7 meters deep with sloped walls and a 1.5 meter wide bench on both the west and east walls 3 meters below the ground surface. Trench 3, also excavated in August 2012, is a deepening of an exposure created by the terracing of an alluvial fan for a local tree farm. The western trench wall is approximately 1.5-2 meters tall while the east wall is $\sim 1$ meter tall. The trench itself is only 1 meter deep. Both Trenches 1 and 2 were excavated by a large excavator while Trench 3 was excavated by hand. Dimensions for each trench are outlined in Figure 4.2. 


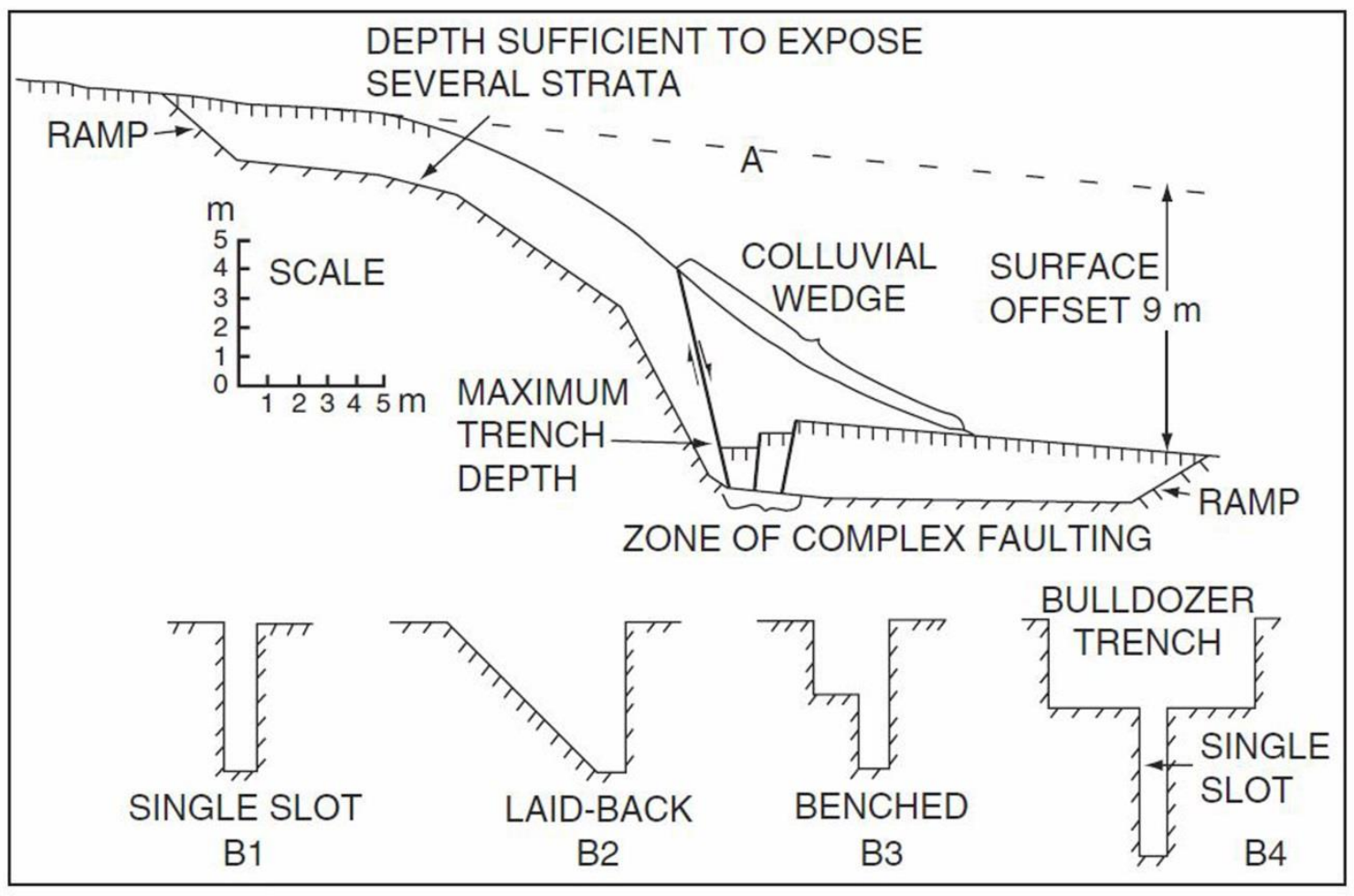

Figure 4.1 Trench styles used in paleoseismic investigations. From McCalpin (2009). 


\section{Paleoseismic Trench Dimensions}

Trench 1
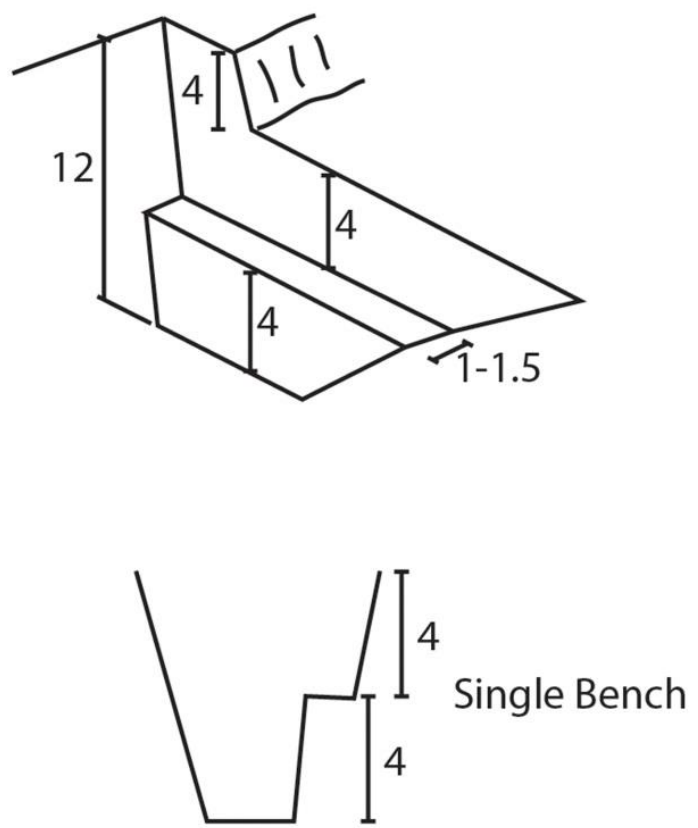

ESE $\longleftrightarrow$ WNW
Trench 2
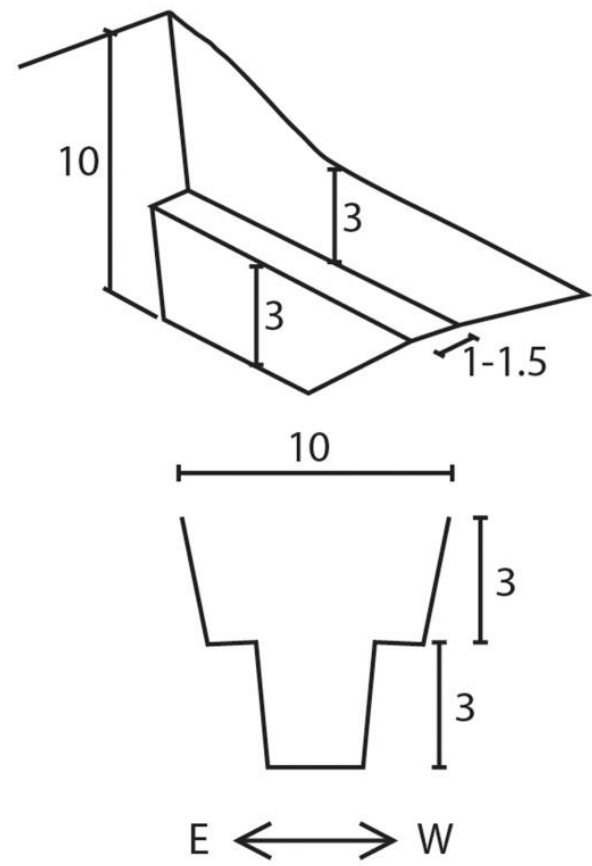

Trench 3
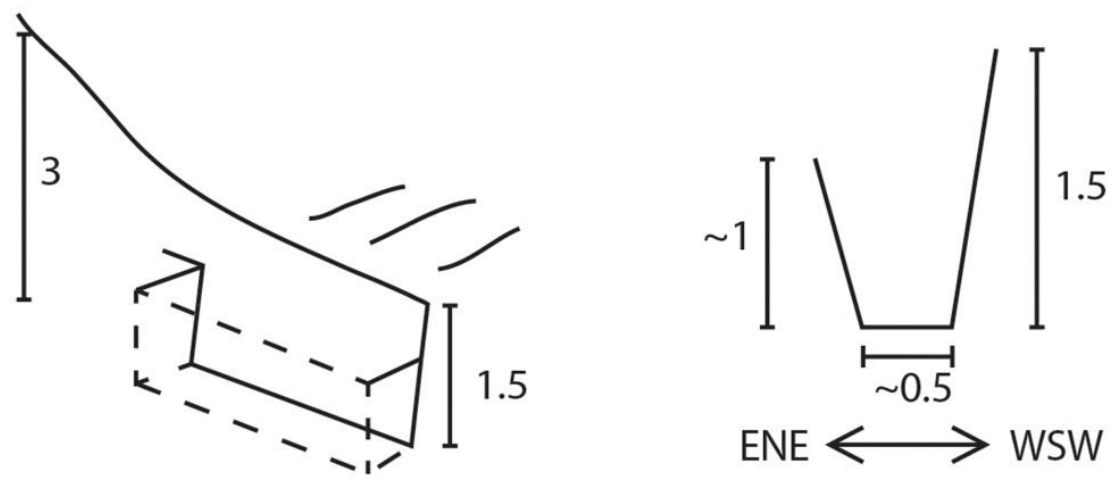

Figure 4.2 The dimensions of all three trenches excavated for this study. Units in meters. 
In order to limit modification from the excavation equipment, wall faces were cleaned after excavation using hand tools including masonry trowels, Nishiri gama hoes and hand held brushes. Any excess dirt left over from the excavation and cleaning of trench walls was removed by hand using a shovel (Figure 4.3). A meter by meter grid was installed on both east and west walls of Trenches 1 and 2 and only on the west wall of Trench 3. Trench logs were drawn directly on orthorectified photographs for Trenches 2 and 3, whereas logging for Trench 1utilized traditional methods of logging on millimeter paper as well as orthorectified photographs.

\section{Trench Logging}

The logging of each one of the three trenches in this study was accomplished using orthorectified photographs as base maps. Orthophotos were generated from stereoscopic photos using Eos Systems Photomodeler Scanner, a close-range photogrammetric software for use with non-metric cameras. Two 40 centimeter rods were placed in the trench for scale as well as direction: one was set vertically, the other horizontally and oriented in a known direction. A series of close-up, stereoscopic photographs were used to produce a three dimensional high resolution point mesh of the desired trench wall, while a few photographs that covered a larger area were used for the model's textures. The point meshes were then cleaned of any redundancies and downsampled to obtain a more manageable number of points while still retaining the original forms present in the trench wall. A surface was then created from the reduced point mesh and textures were projected onto the surface (Figure 4.4). Orthorectified photographs were generated parallel to the trench wall face at a resolution of 20 pixels per centimeter, high enough to keep small details such as texture and grain size visible in 


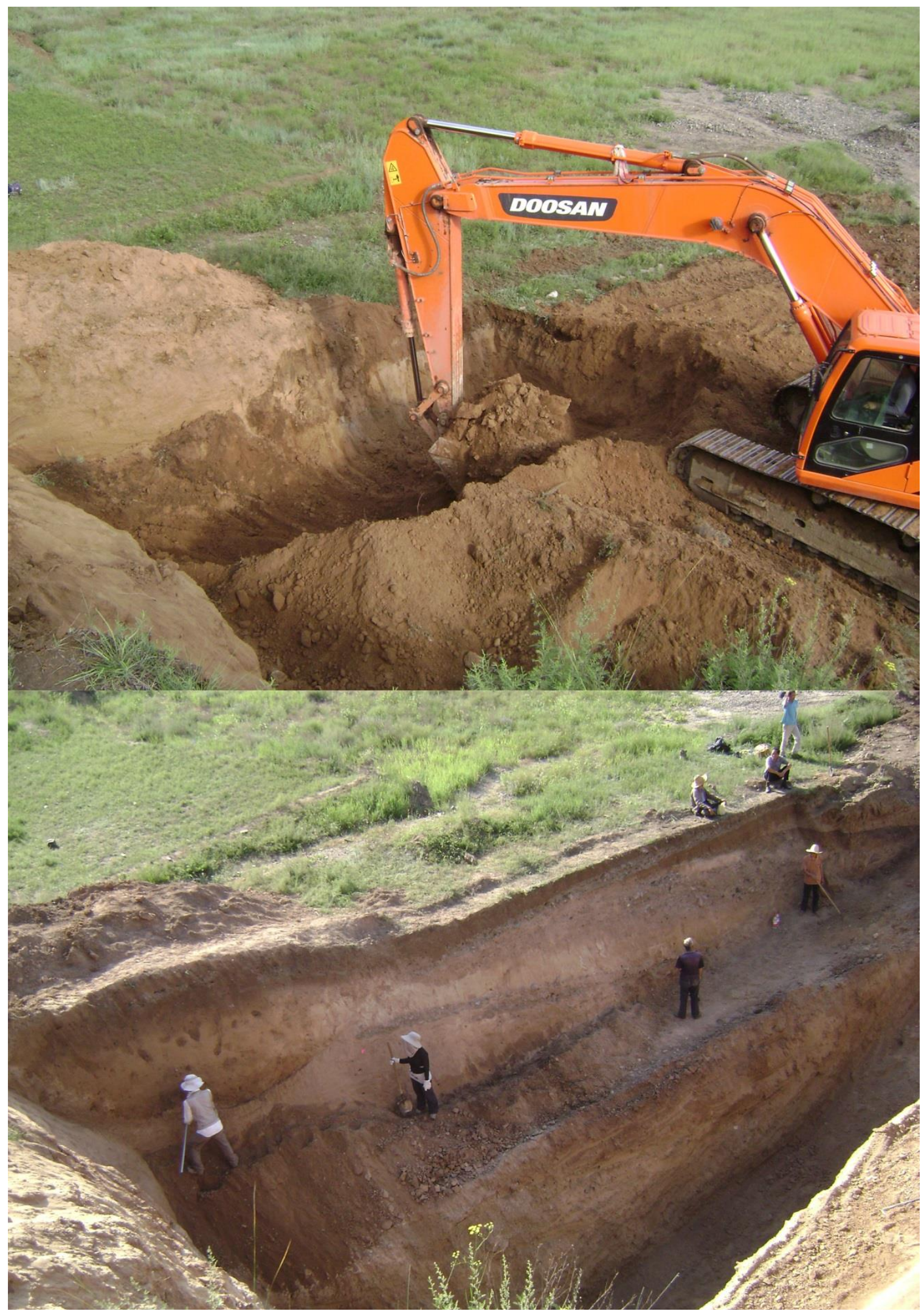

Figure 4.3 Excavation of Trench 2 in August of 2012 using a large excavator (top image) and shovels (bottom image). 


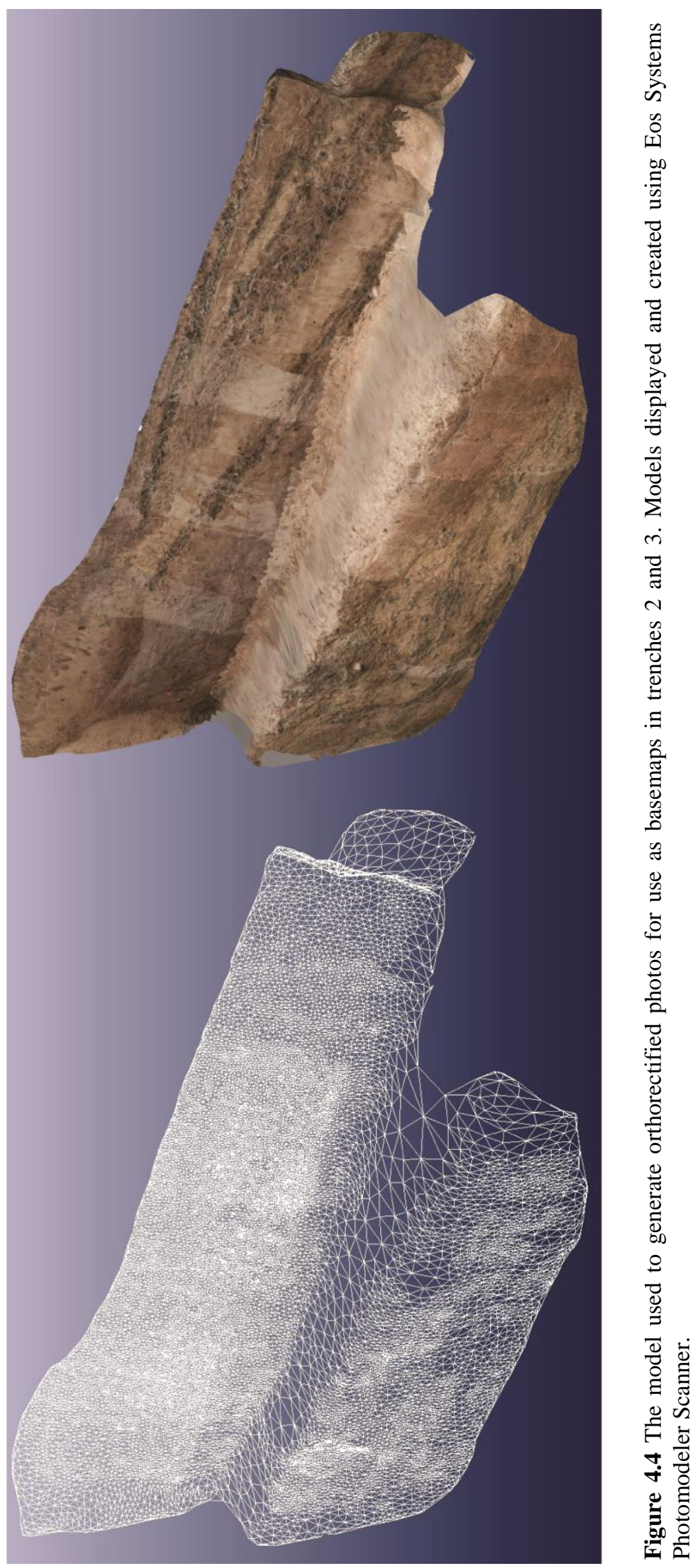

- 42 - 
the images for additional analysis after field work has been completed. The orthophotos were printed at a scale of 1:10 and used as basemaps for logging Trenches 2 and 3.

The trench walls were mapped directly on the printed sections while still in the field, using the trench wall as a way of ground truthing interpretations made on the photographs. While the printed photographs provide a good guide for field mapping, direct contact and examination of the wall face is essential. Many textures and small details can be lost due to the reduction in image size and resolution of the printed images. Orientations of key clasts in the wall face as well as contacts between various stratigraphic units must be double checked before field interpretation lines are drawn, similar to the way one would ground truth structural mapping made from an aerial photograph or satellite image. Imperfect blending of textures throughout the trench may also lead to false or different colors within the same stratigraphic unit, possibly misleading stratigraphic interpretations if they are made from the image only. Additional care must be taken to make sure the $3 \mathrm{~d}$ model that was generated is correct and that the photographs have been projected properly so that everything is in its proper place. If any discrepancies are found, all or a portion of the model may need to be rerun in order to maintain accurate image data.

Mapping directly on photographs has its advantages over traditional trench logging methods using millimeter paper. Speed is one advantage. The orthorectification of the images removes the need for constant measurement of all objects outlined on the trench $\log$ since dimensions are theoretically constant. This also eliminates the necessity of having two people working on one trench log, which speeds up the logging process significantly, especially if communication is an issue. Better accuracy could be another 
advantage to mapping on photographs, though some assumptions are traded for others. While mapping on millimeter paper, the dimensions of the meter grid that was strung up on the wall face are assumed to be constant. In trenches with perfectly flat vertical walls this assumption is accurate, though getting each grid square to be exactly 1 meter by 1 meter is more difficult when there are undulations or curvatures in the wall face and the trench wall is non-vertical so as to be more stable.

\section{Trench 1 - Zhong Zhuang Zhai Trench}

\section{A. Description}

Trench 1 was excavated near the town of Zhong Zhuang Zhai in July of 2011 (For trench location see Figure 3.4). The trench itself was dug across the northern branch of the NWTSF west of the place of bifurcation. The southern wall of the trench cut into the upraised footwall, with the top of the wall ending at a surface that is interpreted as the T2 surface (Figure 4.5). This T2 surface correlates with the T2 surfaces mentioned in Zhang et al. (2007) which has an age of $18 \pm 0.9 \mathrm{ka} B P$.

The scarp across which this trench was cut is approximately 4.2 meters high. It is assumed to be a composite scarp representing multiple faulting events. The trench walls themselves were $\sim 8$ meters tall on the north side of the fault (hanging wall) increasing in height to about 12 meters from the bottom of the trench to the top (the T2 surface). A 11.5 meter bench was cut into the west wall of the trench, $\sim 4$ meters below the current ground surface on the hanging wall side of the fault. Sloped walls and massive loess deposits making up the trench allowed the trench to be deeper, with fewer benches.

Stratigraphy within the footwall of the trench consists of loess, gravels and paleosols that had developed in some loess layers, while the hanging wall contains mostly 


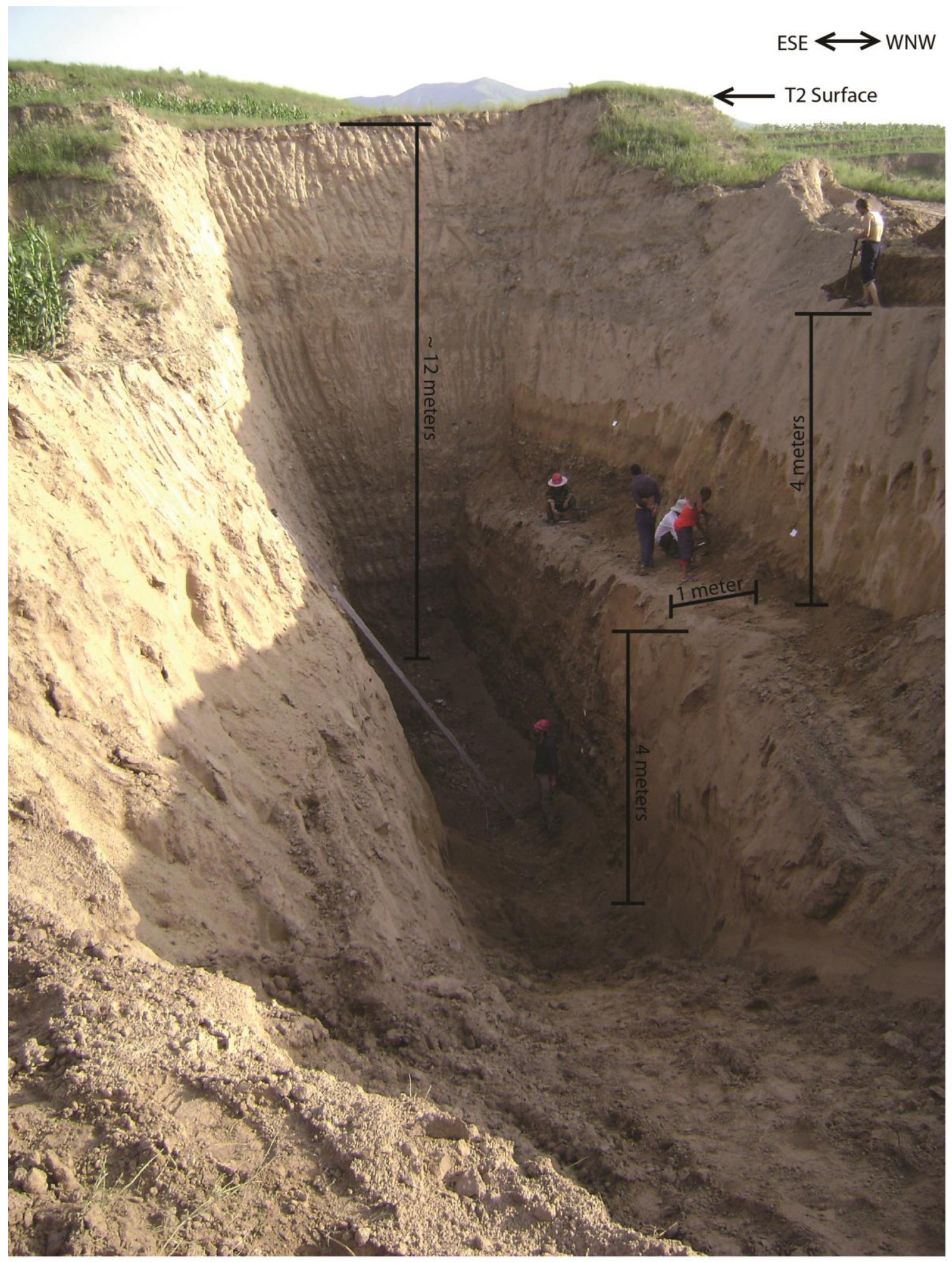

Figure 4.5 A view of Trench 1 from the north. Dimensions for the trench are shown as well as the top of the trench interpreted as the $\mathrm{T} 2$ surface. 
massive amounts of reworked loess, some scattered gravel and a few gravel wedges next to the fault (Figures 4.6-4.8). The hanging wall also has a paleosol visible at the very base of the west wall. One major fault was identified in the trench, visible in both walls and stretching continuously from the floor of the trench to the current ground surface. The approximate dip of the fault changes from $51-55^{\circ}$ to $40-45^{\circ}$, roughly 3.7 meters below the current ground surface. This is best observed in the east wall, since the bench on the west wall lies right at the apparent change in fault dip.

\section{B. Interpretation}

${ }^{14} \mathrm{C}$ ages were obtained from charcoal and bulk soil samples in both the hanging wall and the footwall (Table 4.1). Bulk soil sample BK-01W, taken from the paleosol present in the hanging wall at the bottom of the west wall, has a ${ }^{14} \mathrm{C}$ age of $19070 \pm 60$ years BP. This is close to the previously mentioned T2 surface age of $\sim 18 \pm 0.9 \mathrm{ka}$ BP. Using a variant of the distance formula, if we were to restore these two surfaces to the same level over a period of $\sim 18 \mathrm{ka}$, then total fault movement during that period of time would give us an approximate average slip rate for the fault. Using the average dip observed in the trench $\left(45^{\circ}\right)$ for a maximum slip rate and a typical normal fault dip of $60^{\circ}$ (which is assumed for this fault at depth) for a minimum slip rate, the calculated slip rate would be $0.7-0.9 \mathrm{~mm} / \mathrm{yr}$. This is consistent with findings from Liu et al. (1991) though it is less than findings from Ding et al. (2010).

Some assumptions need to be taken into consideration when looking at the previous slip rate calculation. First of all, the top of the trench is assumed to be the T2 surface based on scarp measurements and surface morphology. The surface itself has not been dated in that exact location. The surface could also have been modified by erosion 


\begin{tabular}{|c|c|c|c|c|c|}
\hline Location & Sample Name & Material & Delta13C & Radiocarbon age (BP) & $2 \sigma$-calibrated age range \\
\hline Trench 1 & C-13W & charcoal & -24.2 & $160 \pm 25$ & 1665-1954 AD \\
\hline Trench 1 & C-26W & charcoal & -24.8 & $900 \pm 25$ & $1041-1211$ AD \\
\hline Trench 1 & BK-02W & bulk soil & -23.9 & $25950 \pm 80$ & $29062-28500 \mathrm{BC}$ \\
\hline Trench 3 & BK07 & bulk soil & & $36750 \pm 270$ & 40218-39304 BC \\
\hline Trench 3 & BK08 & bulk soil & & $2700 \pm 30$ & $905-806 \mathrm{BC}$ \\
\hline Trench 3 & BK09 & bulk soil & & $2330 \pm 30$ & $508-260 \mathrm{BC}$ \\
\hline Trench 3 & BK10 & bulk soil & & $29900 \pm 180$ & 33035-32119 BC \\
\hline Trench 3 & BK11 & bulk soil & & $28820 \pm 170$ & $32480-30843$ BC \\
\hline Trench 3 & BK12 & bulk soil & & $27090 \pm 130$ & 29596-29201 BC \\
\hline
\end{tabular}

Table 4.1 Calendar calibrated radiocarbon ages of samples found in Trenches 1 and 2. Calibrations were made using Oxcal calibration software. 


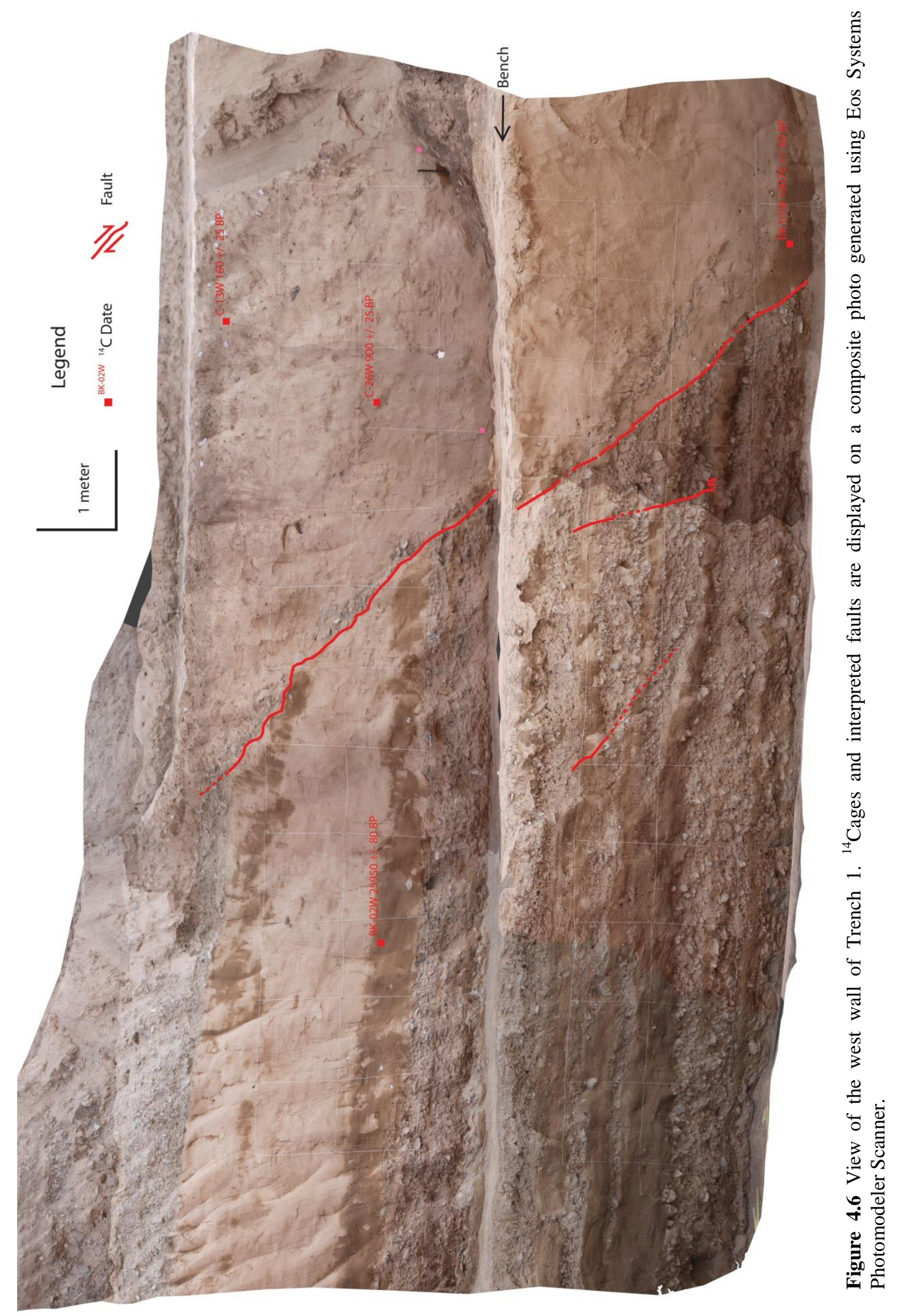




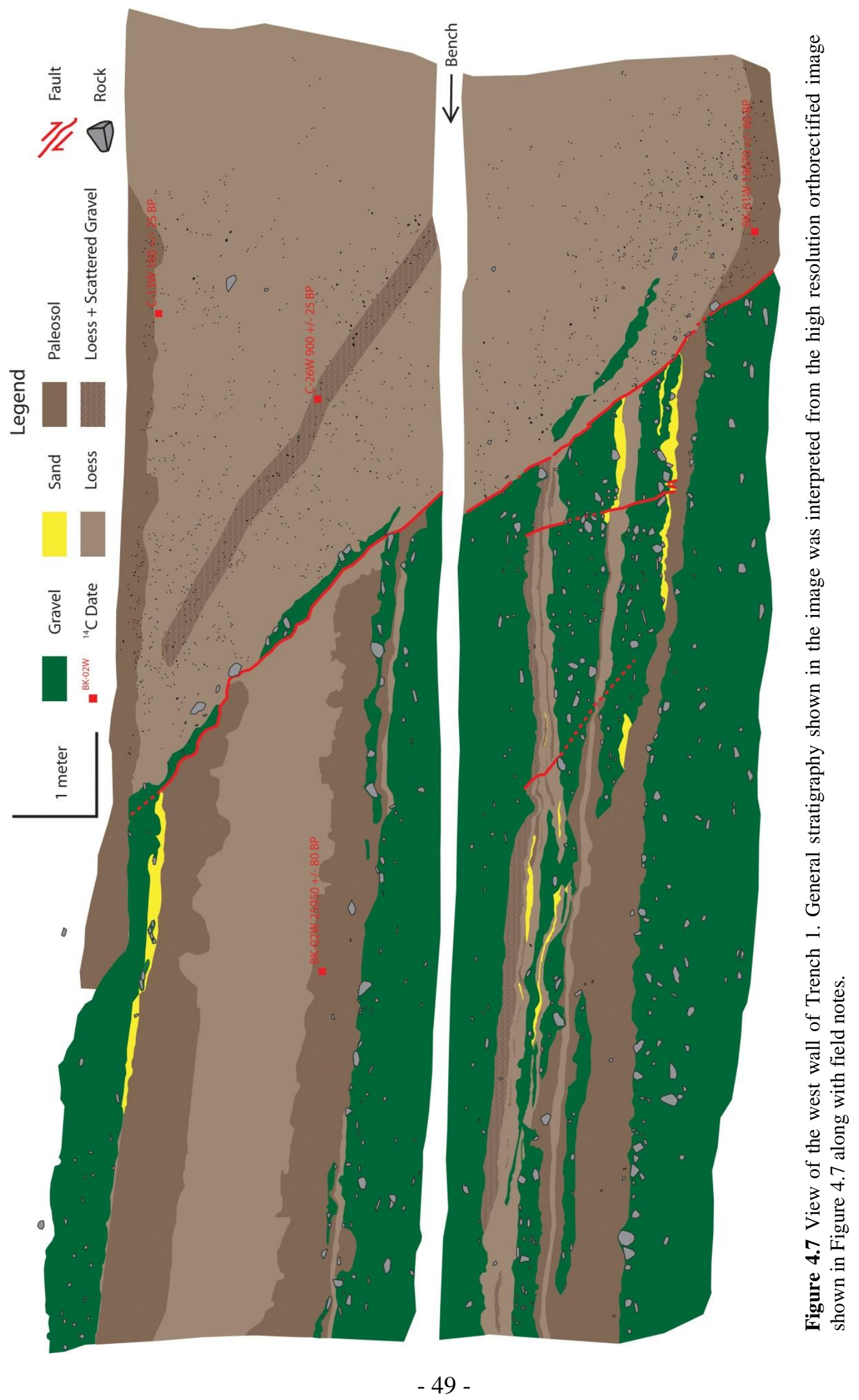




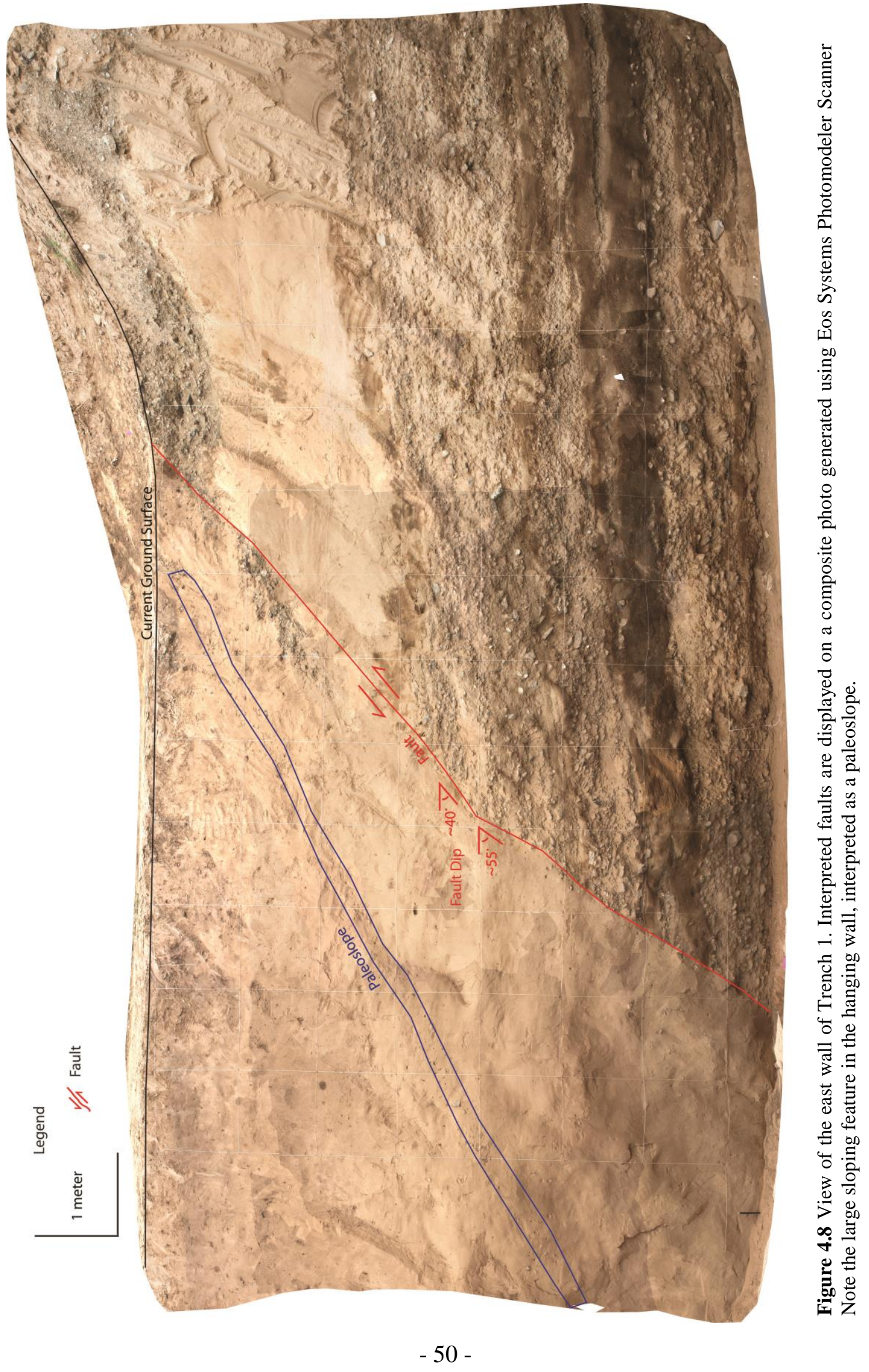


and/or anthropogenic sources such as cultivation. It is already known that the current land surface at the base of the scarp has been modified by human activity since the trench was excavated in a corn field.

Sedimentation rates could also affect the slip rate calculation and can be estimated by looking at the other bulk soil sample date in the footwall. This sample $(\mathrm{BK}-02 \mathrm{~W})$ has a ${ }^{14} \mathrm{C}$ age of $25950 \pm 80$ years $\mathrm{BP}$ and is approximately 7.3 meters below the T2 surface. This gives you a sedimentation rate of $\sim 0.9 \pm 0.1 \mathrm{~mm} /$ year, again assuming the T2 surface has an age of $18 \pm 0.9 \mathrm{ka}$. With the difference between BK-01W and the T2 surface age being approximately 1000 years, if you assume similar sedimentation rates you subtract $\sim 1.2$ meters from the fault slip, dropping the slip rate estimates by $\sim 0.05 \mathrm{~mm} / \mathrm{yr}$.

With the addition of sedimentation rates to the slip rate calculation we assume that the sedimentation rate in the footwall is similar to that of the hanging wall. Charcoal sample $\mathrm{C}-26 \mathrm{~W}$ in the hanging wall has a ${ }^{14} \mathrm{C}$ age of $900 \pm 25$ years BP. This sample is located in an $\sim 1 / 4 \mathrm{~m}$ thick sedimentary layer defined by a loose concentration of small gravel within reworked loess. The layer has a dip of approximately $29^{\circ}$ to the Northeast and extends from the current ground surface to the bottom of the trench. It is visible in both walls, yet appears more strongly in the east wall (Figure 4.8). This surface could be interpreted as a paleoslope which, if C-26W is representative of the layer's age, would indicate that there was a significant depositional slope that isn't there today. This would also suggest that there was a significant amount of deposition on the north side of the fault within the last 900 years. 


\section{Trench 2 - NBT - Large Trench}

\section{A. Description}

Trench 2 was excavated in July of 2013 between the villages of Nanyukou and Zhong Zuang Zhai. The trench stretches across the main NWTSF just east of the fault bifurcation to the west. The overall strike of this section of the fault is roughly $280^{\circ}$, though geomorphological evidence of the fault (the apparent fault scarp) suggests the fault turned to the south and is oriented to $\sim 085^{\circ}$ (Figure 3.5). Therefore the trench was excavated with an orientation of roughly $355^{\circ}$ in order to be parallel to the fault trace.

The trench is 10 meters wide, 6.5 to 10 meters deep and 18 meters long, stretching across the fault scarp (Figure 4.9). A single $\sim 1.5$ meter wide bench was set in both east and west walls, 3 meters down from the current ground surface on basin side of the fault (northward, downthrown side). The trench walls were slightly sloped so as to increase trench wall stability.

Faults within the lower 3 meters of the west wall on the southern end of the trench were identified through observed shear fabric including grain alignments as well as truncated gravel beds and abrupt horizontal color changes between adjacent loess layers. Two branches off a single main normal fault were observed at the southernmost end of the trench (Figure 4.10). Both faults are dip-slip faults with a normal sense of slip and the downthrown side to the north.

Sediments within the footwall on the southern side of the southernmost fault (Fault 1) were a mix of dark and light brown silts with scattered gravel throughout. A small portion of bedrock was exposed at the very bottom corner of the southwestern part of the trench. Fault 1 has a dip of $\sim 70^{\circ}$ to the north, with a 0.5 meter step dipping roughly 


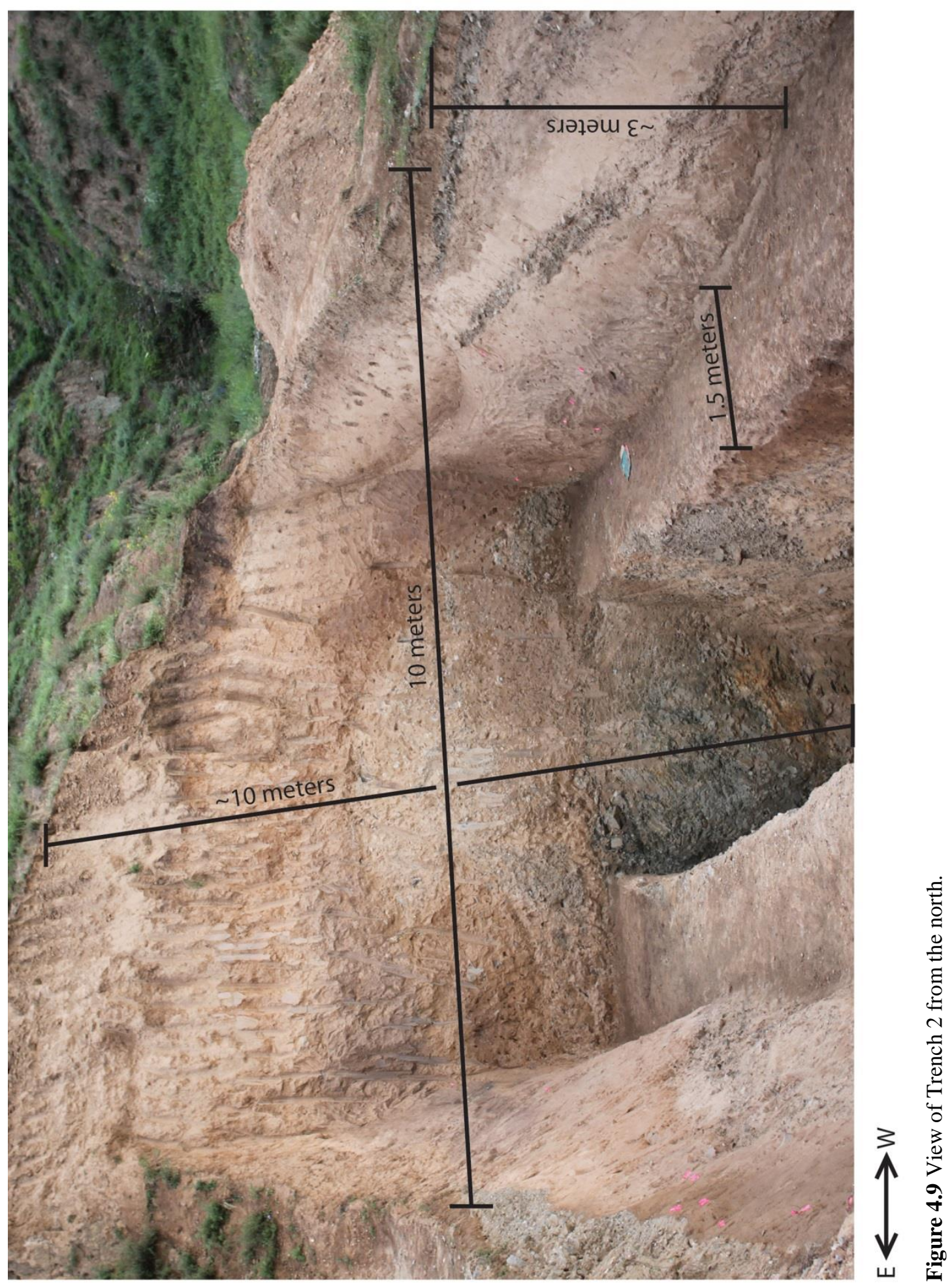




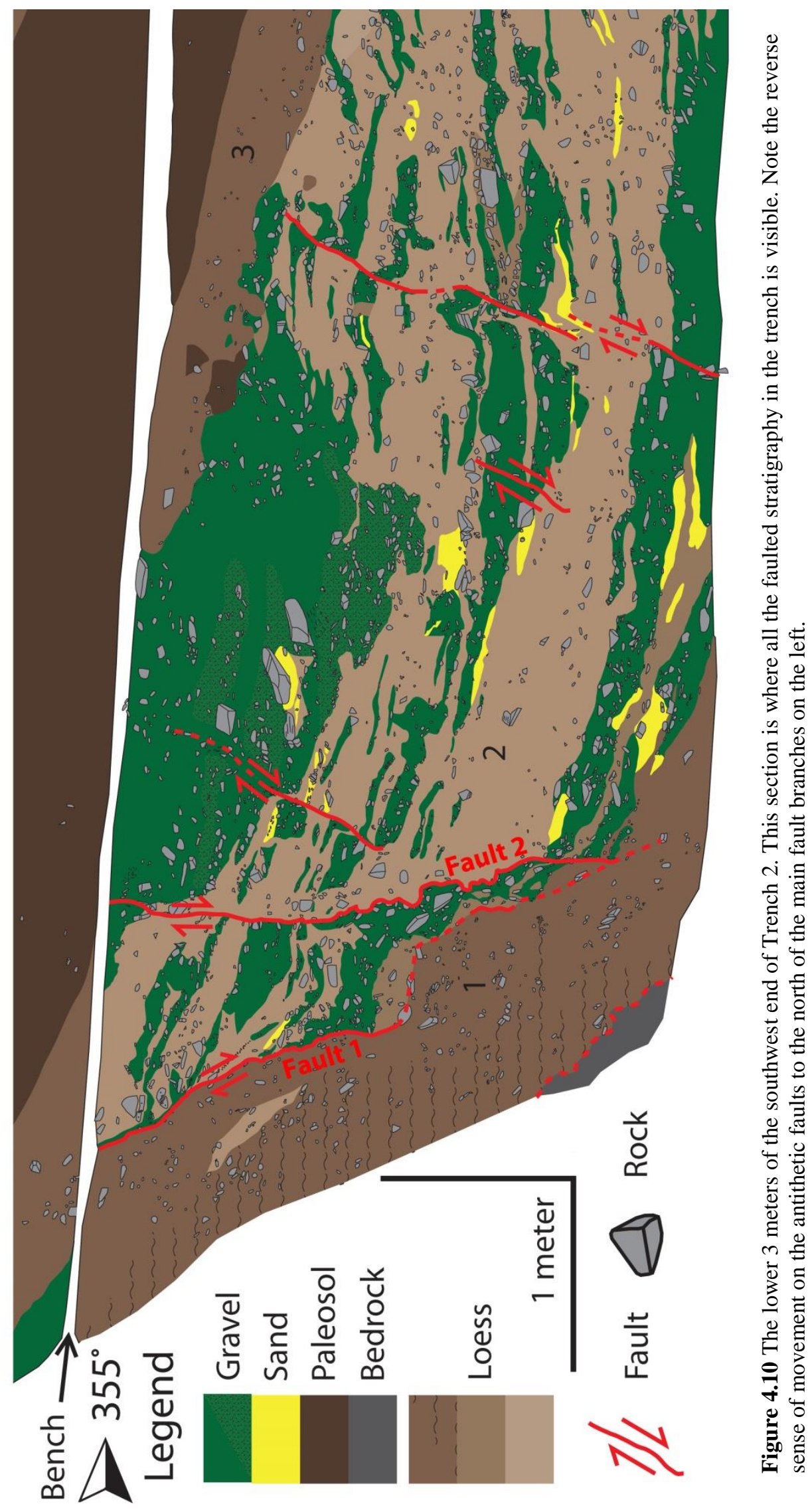


$10^{\circ}, 1.5$ meters from the bottom of the trench. Any hint of stratigraphy on the south side of this fault is also dipping 60 to 70 degrees to the north.

Sediments adjacent to Fault 1 on the north side include large amounts of tan loess intermixed with small to large gravel beds dipping between 10 and 20 degrees to the north. The other branch of the main normal fault (Fault 2) on the north side of Fault 1 is oriented near vertically and is clearly offsetting multiple gravel beds within the loess. Several secondary faults are present within 3 meters to the north of Fault 2. These faults are antithetic to the main fault and have a reverse sense of slip.

Farther to the north of the faults, in the lower 3 meters of the west wall, the dip of the gravel beds within the massive loess begin to shallow and then gradually start to dip to the south, away from the Daixian Basin and toward the mountains. Gravel beds in the lowest part of the northernmost end of the trench are dipping $\sim 20^{\circ}$ to the south. Interpreted stratigraphy for the west wall is displayed and numbered in Figures 4.11 and 4.12 .

An erosional surface with an apparent dip of $\sim 20^{\circ}$ to the north truncates Faults 1 and 2 as well as the massive tan loess/gravel bed at the base of the trench. The exact point of truncation of the faults by the erosional surface is obscured by the bench, while the erosional surface extends down to 2 meters below the bench on the northern side. Above the erosional surface are thick layers of light to dark brown paleosols and tan loess with apparent dips shallowing as you move upward on the trench wall. These layers show a varying degree of clastic input, with layer 4, 10-12 and the upper part of layer 6 containing almost no gravel sized clasts (See Figure 4.12 for layer numbers). Starting just below layer 13 near the top of the trench, sedimentary layers change suddenly to nearly 


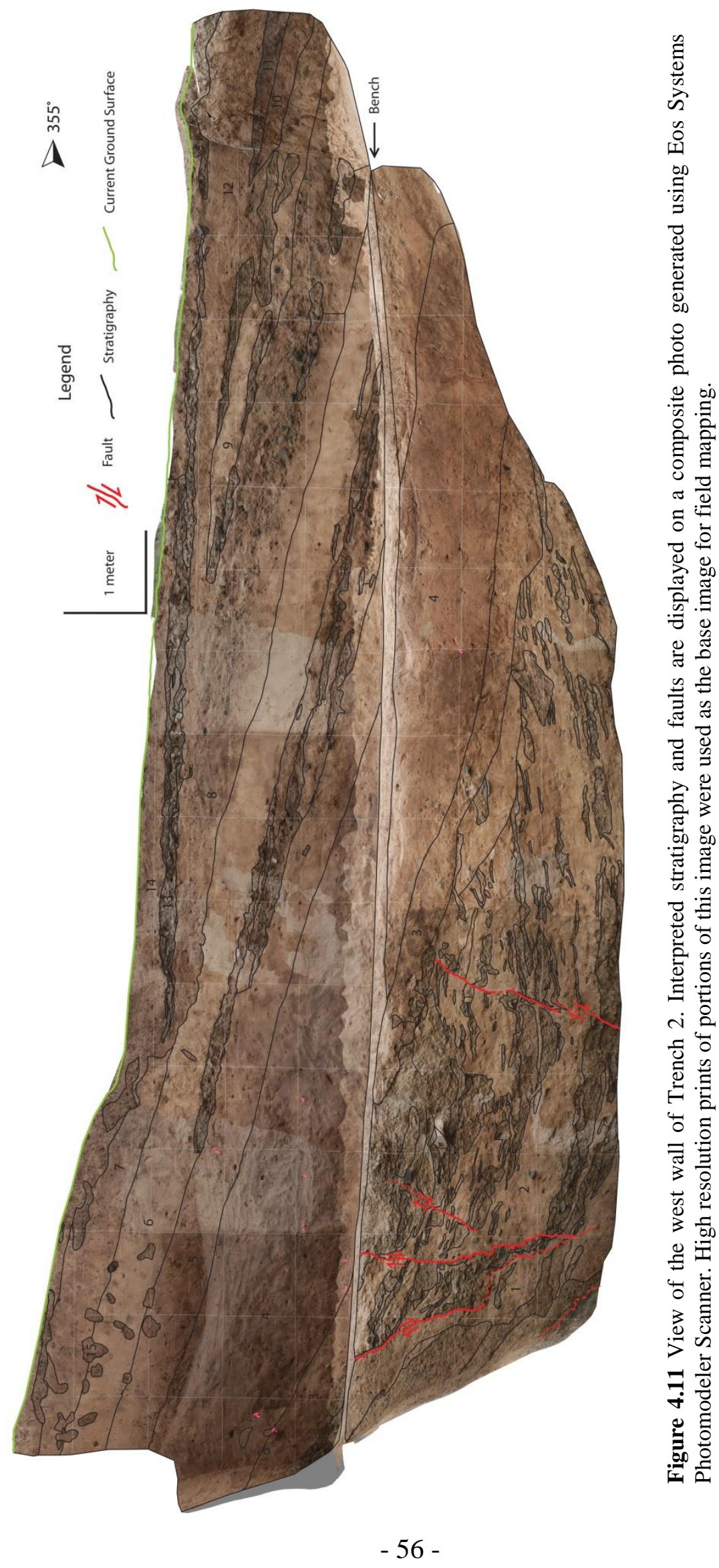




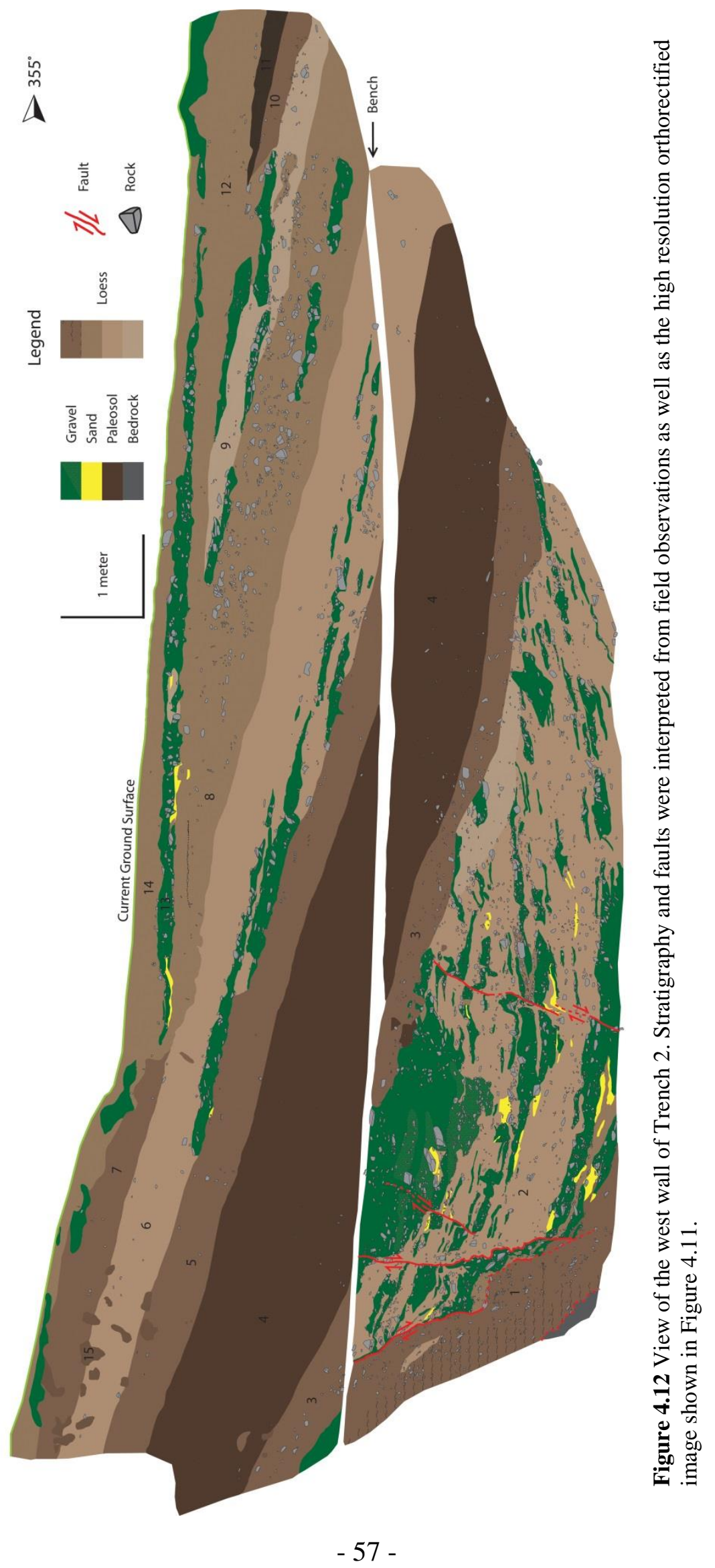


horizontal. Large filled burrows were identified in some layers, including layers 3 and 6 .

The east wall shares a few similarities with the west wall but has some notable differences as well. Upper stratigraphy contains dark brown paleosols (layers 5, 7, 9, 13) as well as some light tan loess layers $(3,6,8,12)$ (Figures $4.13 \& 14)$. Layers 10 and 11 are large gravel beds just underneath the current ground surface. These are likely modern fluvially derived gravels.

The lower east wall stratigraphy consists of a massive tan loess layer with intermixed gravel beds, most dipping roughly $20^{\circ}$ to the south. A few gravel beds on the uppermost part of the south end of the lower bench dip toward the north or have no apparent dip. Bedrock outcrops on the very south side of the lower east wall, and gravel beds are conspicuously absent for 3.5 meters north of the south wall. In their place are scattered gravels of various sizes spread throughout the loess.

Despite being only 2.5 meters east of the lower west wall, the lower east wall shows none of the signs of faulting at its southern end as the southern part of the west wall. There are no obvious or consistent grain alignments, no offset gravel beds and no abrupt color change within the loess.

\section{B. Interpretation}

Anthropogenic modification of the uppermost parts of the trench is observed starting just below layer 13 in both the east and west walls. This is where the stratigraphy suddenly becomes near horizontal, likely due to terracing for agricultural purposes.

The lack of gravel beds in the southernmost 3.5 meters of the lower wall could be an indication of fault activity. A large amount of offset on a fault present, but not visible, between the loess/scattered gravel and the concentration of gravel beds could have 


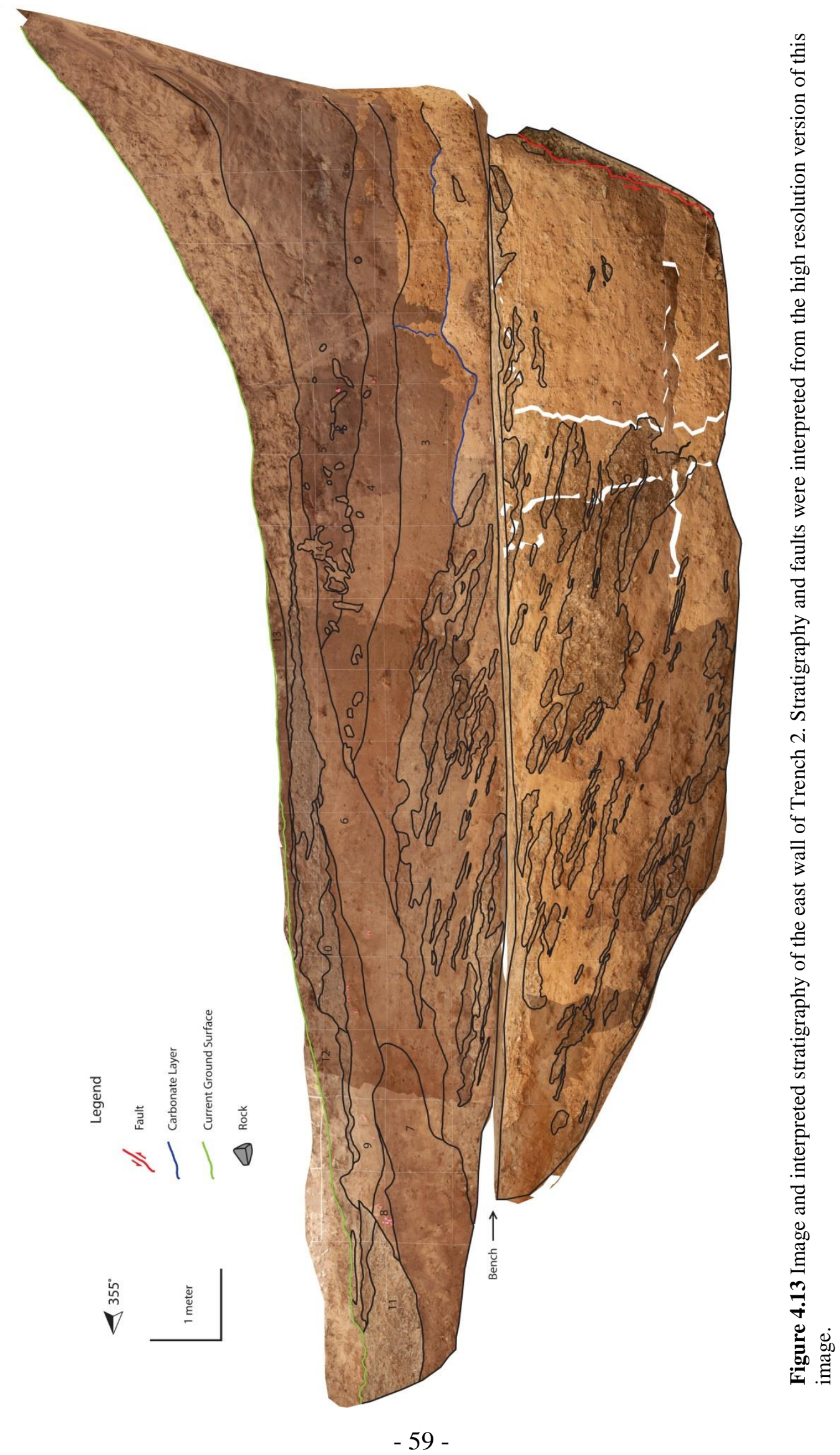




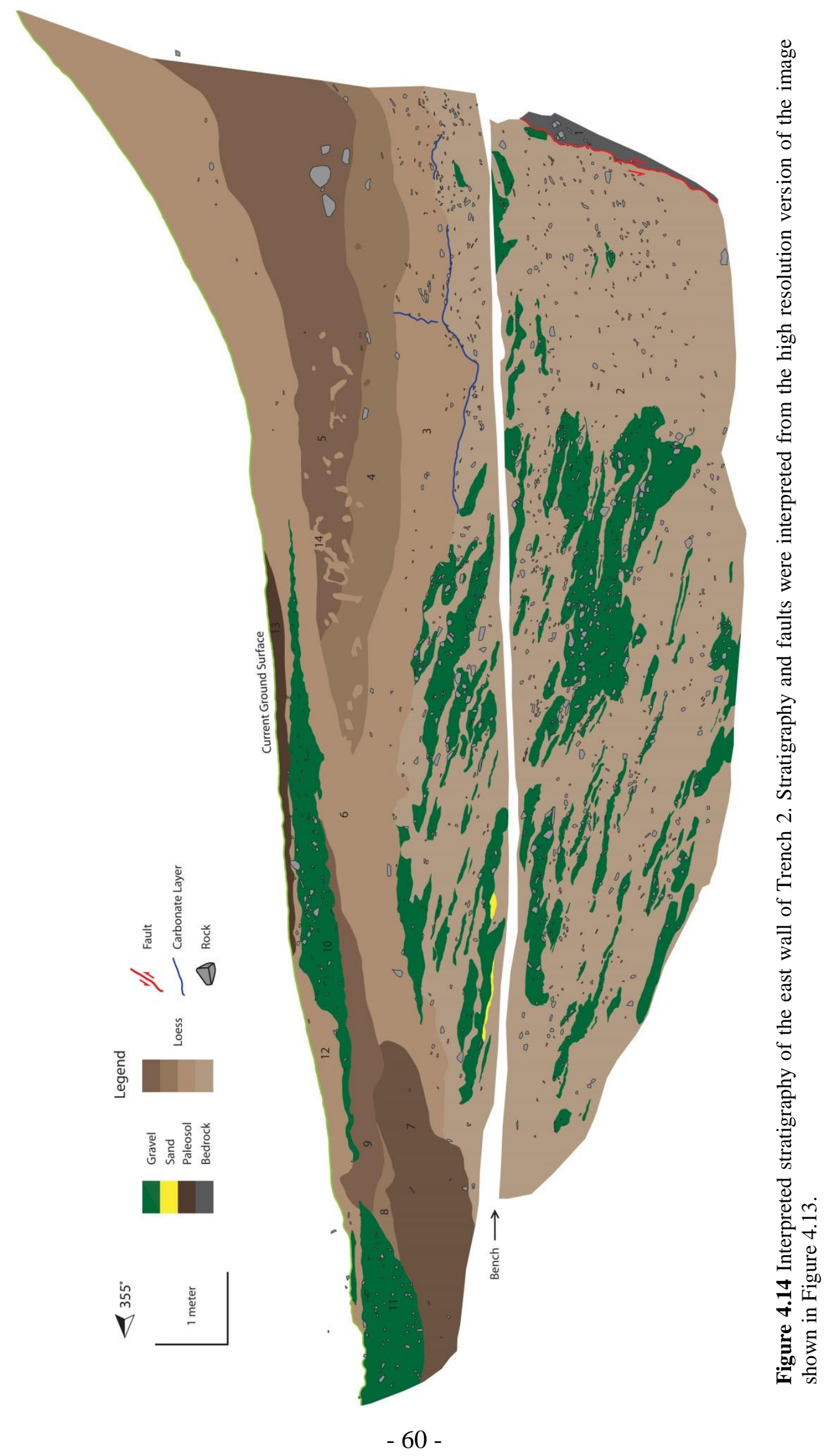


repositioned them to be at the same stratigraphic level. Alternatively, the lack of gravel beds could simply indicate a change in the source of sediment deposited on that slope (e.g. sediment coming from the north contained more gravel than that from the south). To the north and east of the trench is a large alluvial fan coming from a drainage $0.35 \mathrm{~km}$ to the east (Figure 3.6). Small gravels from the edge of this fan could have been deposited southward toward the hills, while loess deposited on the side of the hills could have been washed to the north, with the occasional bits of gravel that eroded off the bedrock. Northward dipping beds on the lower west wall contain more gravel likely due to the closer proximity of the west wall to the small drainage west of the trench.

The antithetic sense of deposition present in the lower parts of Trench 2 complicates the paleogeomorphologic interpretation of this area. One hypothesis is that it could be due the result of a stream running along the fault scarp. The origin of this stream would likely be the drainage just east of the trench, between the trench and the source for the large alluvial fan. Flow from that drainage basin would be deflected to the west by the fan, running right along the fault scarp between the fan and the scarp. Flow from the drainage might be augmented by waters shed off the alluvial fan itself. Sediment washed southward from the alluvial fan would deposit in a reverse sense from that from the north, while additional sediment could be carried in from the east by the stream.

If the climate changed and stream power dropped or stopped altogether then downcutting or erosion would stop. This could also happen locally if the stream was able to avulse to a channel further to the north. The downwarping geometry of layers 3, 4 and 5 suggests that fine sediments could have gradually filled the channel cut by the stream. This would have ultimately resulted in a more typical basinward dipping of erosional 
surfaces and sedimentary layers, starting with the tan loess layer 6 in the upper part of the east wall.

Evidence that supports the stream hypothesis can be found aerial imagery of the area as outlined in Figure 4.13. The RTK GPS survey discussed in Chapter 3 also covered a small portion of that stream (Figure 3.7). This is reflected in Profile 2 (Figure 3.9). Additionally, the large gravel bed (11) in Figure 4.13 makes up the bottom of the current stream channel. It is most likely derived from that stream system.

An alternative hypothesis for the reverse sense of dip of these gravel beds could be that they were tilted due to fault movement. However, their fairly consistent dips within at least 35 square meters of the east wall would suggest the entire block rotated as one unit. Given the apparently undisturbed stratigraphy in relatively unconsolidated sediments this seems unlikely. Rotation of a block consisting only of unconsolidated sediments would likely disturb any layering or stratigraphy within that block, leaving evidence of its rotation.

The overall complexity of Trench 2 could be caused by a variety of factors. A change in sedimentation rates and depositional power of streams coming from drainages surrounding the trench is to be expected in any area where climate fluctuates over time. Erosion due to change in climate or base level should also be expected, especially in an area with known fault activity. The lateral migration of the Yangyan River to the northeast could also result in erosion or aggradation on the hillslope as the river moves closer or further away. The extreme and sudden difference between the east and west walls of the trench is most likely related to the spatial location of the trench. The southern wall of the trench shows an arcing pattern of stratigraphy centered on the middle of the 
trench (Figure 4.15). This suggests that at least the sediments visible in the south wall were deposited on a rounded tip of a hill pointed in the direction of the trench. This could be the cause of differences in apparent erosional surfaces and depositional slopes.

A single main fault could be between the tan loess and bedrock contact at the southernmost end on the east wall of the trench. This fault could be accommodating both branches of normal sense dip-slip fault movement that is present in the west wall. As observed in figure 3.5 , the trench is located close to the exact position where the main branch of the NWTSF changes strike from $\sim 280^{\circ}$ on the east side of the trench to $\sim 240^{\circ}$ on the west side of the trench. The bifurcation of the main branch happens just west of the trench as well. The rapid change of fault geometries could simply be a result of the change in fault strike in that area.

\section{Trench 3 - NST - Small Trench}

\section{A. Description}

Excavated in July 2012, Trench 3 is a continuation of an artificially exposed outcrop across the NWTSF near the village of Nanyukou. In this trench, only the west wall was examined, since the eastern wall had been removed during the terracing for the tree farm. In total, the west wall is 1.5 meters high in the trench, increasing to 3 meters as you move to the south end (Figure 4.16).

Stratigraphy within the trench consists of yellowish tan reworked loess, paleosols and gravel beds (Figure $4.17 \& 4.18$ ). A thin dark paleosol bed on the south side of the trench near the current ground surface is approximately 22 centimeters thick and is dipping $\sim 34^{\circ}$ to the north. This soil is interpreted as having formed on a slope. Other stratigraphy above and below this layer, made up of loess and gravels, have similar dips 


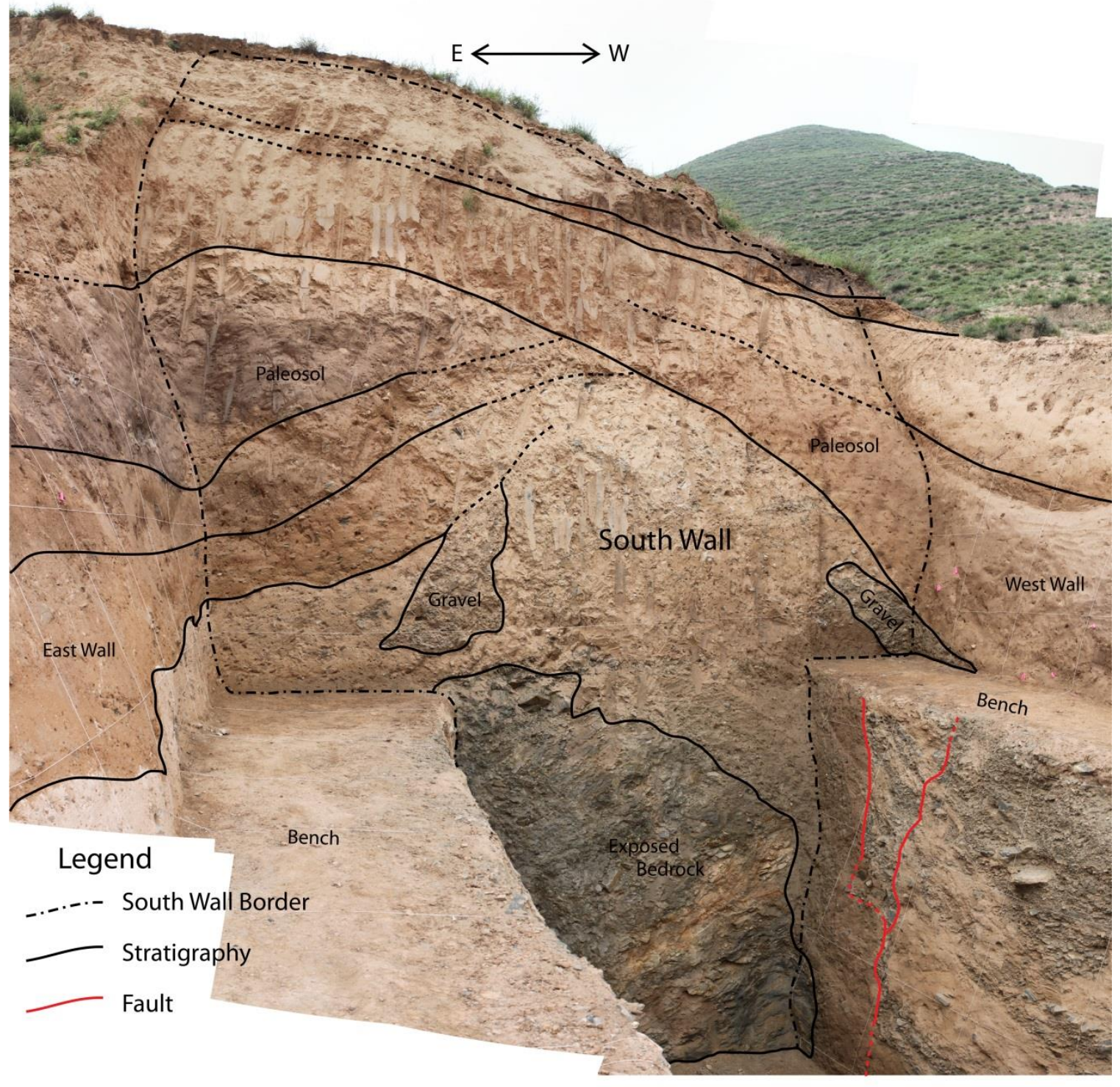

Figure 4.15 The southern wall of Trench 2 as seen from the north end of the east wall bench. Note the arching structure of the stratigraphy in the south wall. Bedrock is exposed in the lower 3 meters of the trench. 


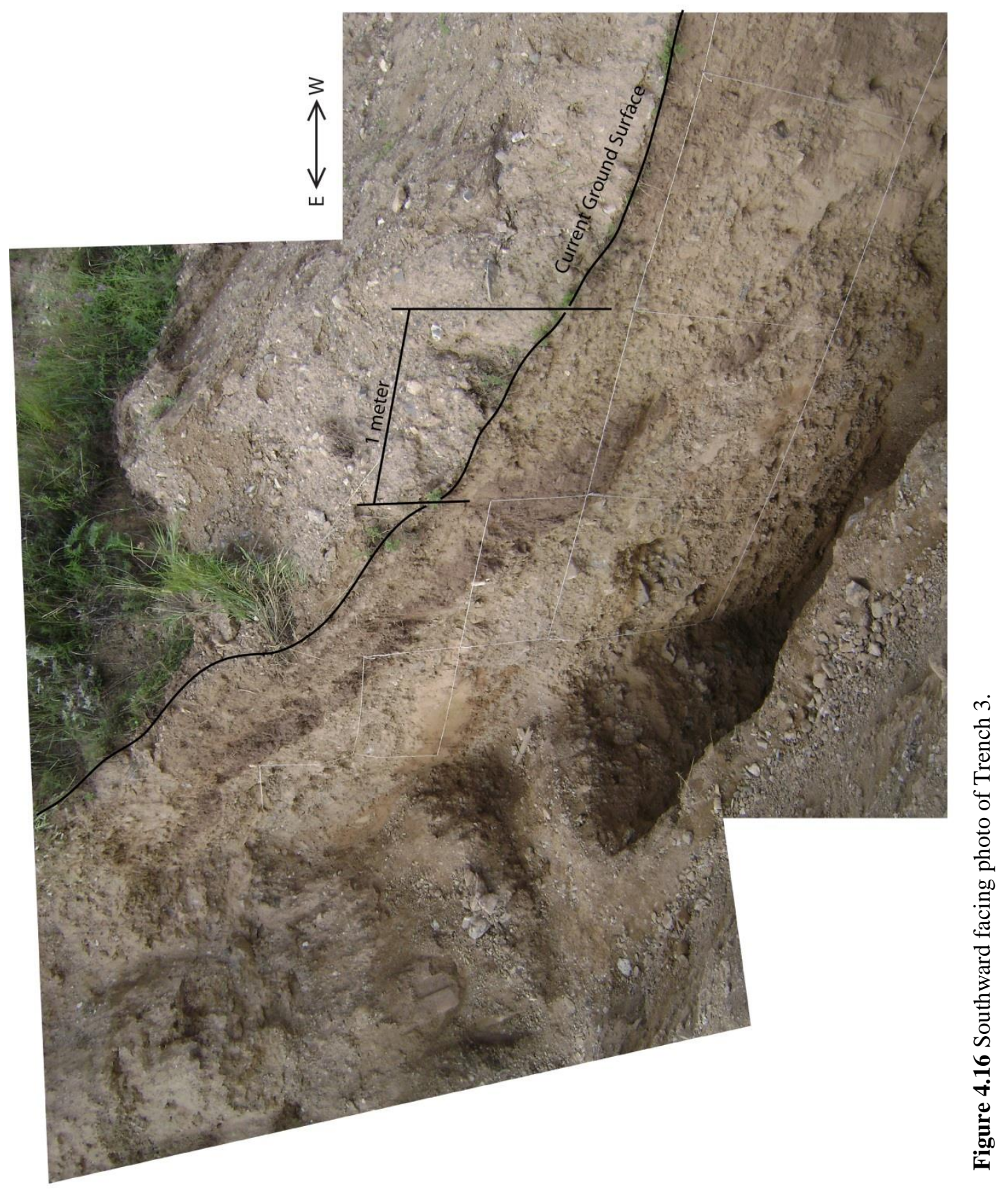




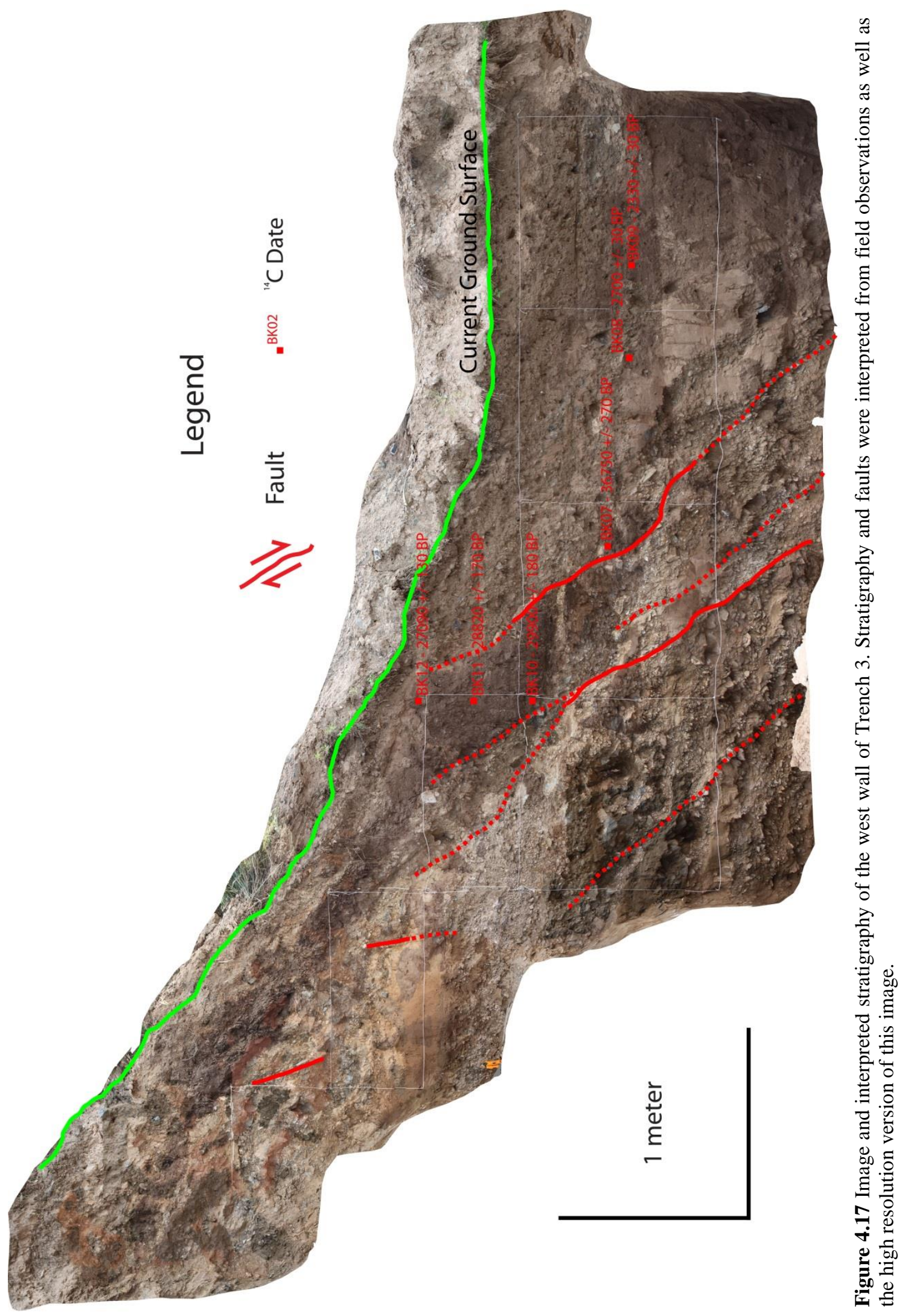




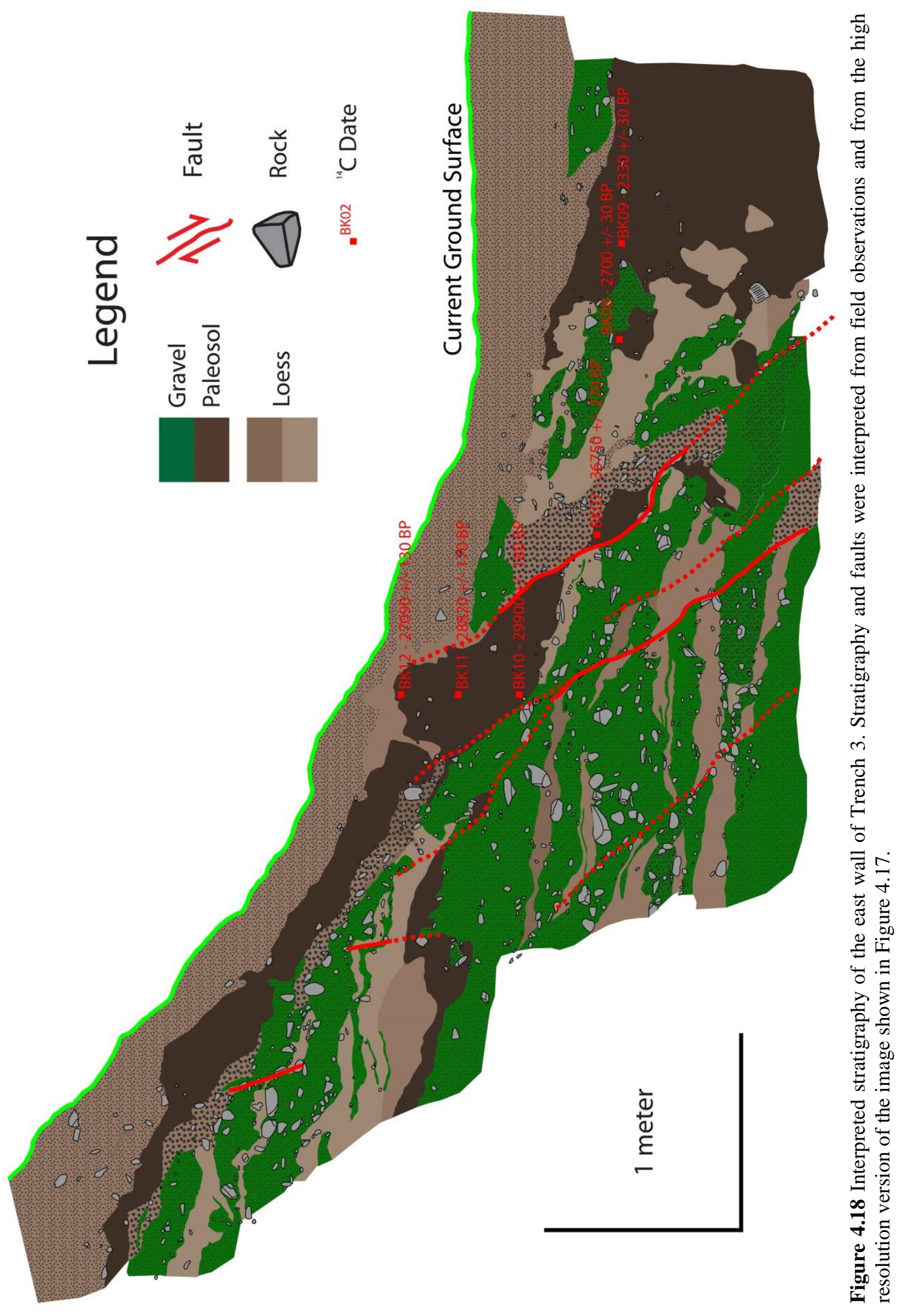


to the north.

Radiocarbon dates of bulk soil samples taken from the sloping paleosol yield dates ranging from 27000 years BP to 30000 years BP (BK12, 11 and 10). Another large dark brown paleosol is present in the northernmost part of the trench. This paleosol is at least one meter thick. Two bulk soil samples from the top of this layer show much

younger ${ }^{14} \mathrm{C}$ ages: $2700 \pm 30$ years $\mathrm{BP}$ and $2330 \pm 30$ years $\mathrm{BP}(\mathrm{BK} 08 \& 09$ respectively).

Three main faults and four secondary faults have been identified in the trench wall. Evidence for faulting includes offset stratigraphy and shear fabric including grain alignments. Palinspastic reconstructions of the trench wall were made using Midland Valley's 2d MOVE software (Figure 4.19). Stratigraphy was divided into 12 layers based primarily on interpreted correlating erosional surfaces. This led to some combination of sediment layers with different ages such as layer 11, which contains all of the radiocarbon ages that were obtained for this portion of the trench.

\section{B. Interpretation}

A minimum of two events were interpreted for this trench. Figure $4.18 \mathrm{~B}$ shows the last event observed in the trench. Offsets were restored using layers $5-11$. Restored offsets along two separate faults equaled 0.42 and 0.27 meters for a cumulative offset of 0.69 meters. The penultimate event shown in Figure 4.18 C also restores offsets on two different faults. Layers $1-4$ were restored 0.17 meters on one fault, while an offset in layer 4 of 0.74 meters was restored on a fault further to the north. This offset is a minimum offset since the lower sedimentary contact is below the trench floor. These two offsets give you a cumulative offset of 0.91 meters. 


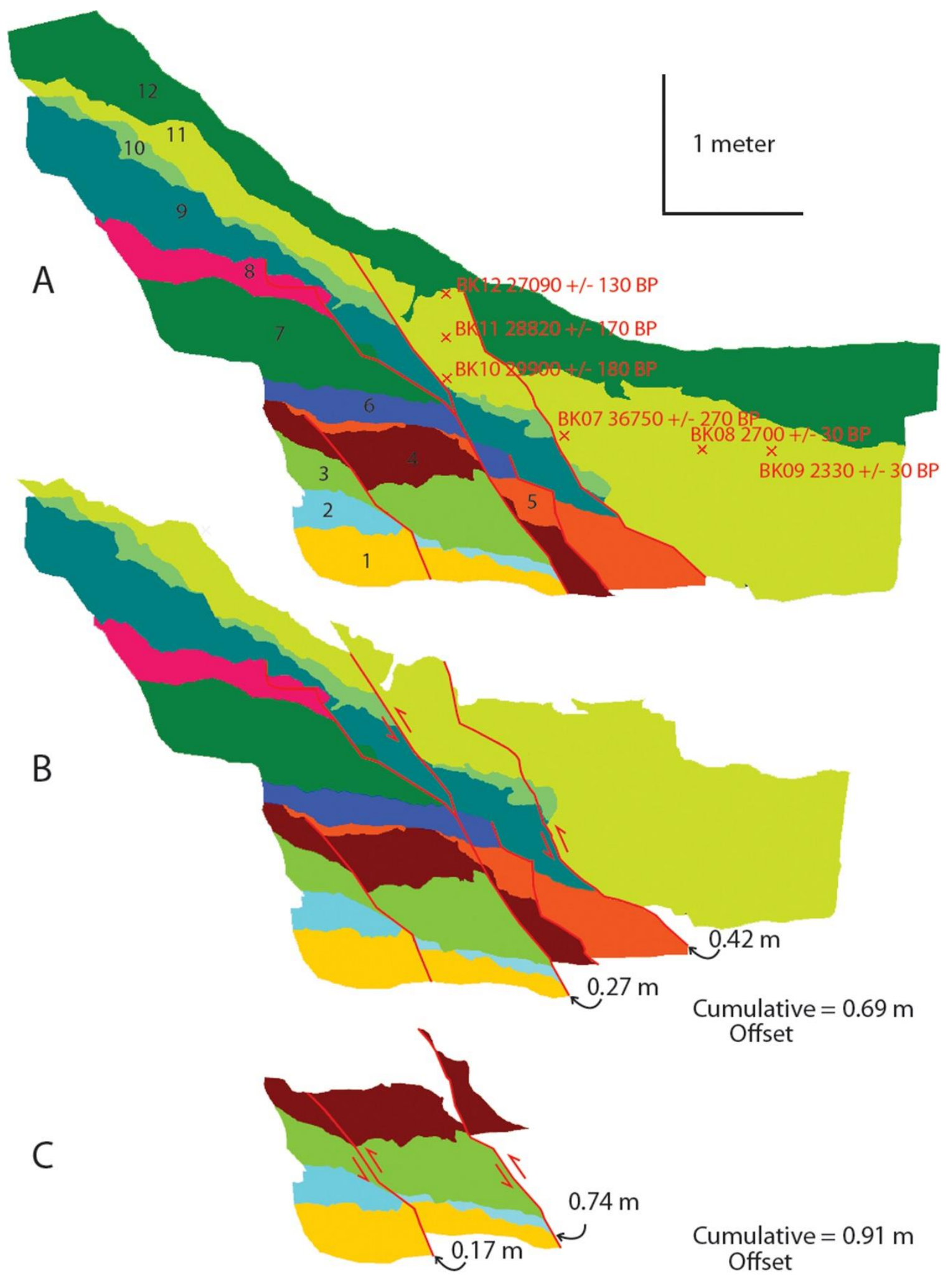

Figure 4.19 Palinspastic reconstructions of Trench 3 showing two interpretations of slip along 4 main faults within the trench wall. The lower image $(C)$ shows the penultimate event, the middle image (B) shows the ultimate event and the upper image (A) shows the stratigraphy as it is today. Reconstructions were accomplished using Midland Valley 2D Move. 
Cumulative offsets for each interpreted event are less than 1 meter. This displacement is significantly less than other event offsets recorded along the NWTSF including Li et al. (1991), Ding et al. (2010) and even in the fault scarp measurements reported in Chapter $3(2.9 \& 3.7 \mathrm{~m})$. This could be due to a variety of factors including the complexity of the trench stratigraphy. The lack of adequate datable material in the trench excludes the possibility of restoring layers by age. Many erosional events visible in the trench wall could have removed younger layers which might have displayed clear single event offsets. This idea is supported by the bulk soil age of $27090 \pm 130$ BP located just 20 centimeters below the current ground surface.

We are also limited by the size of our trench. Additional slip could have been accommodated by faults not visible in the trench due to its limited extent. Additionally, a 3 meter offset cannot be observed in a 1.5 meter deep trench. If the site for Trench 3 is analogous to Trench 1, then the layer that corresponds to the sloped paleosol mentioned above would be found $\sim 8$ meters below the ground surface.

\section{VI.Discussion}

\section{A. Local Geomorphology}

Evidence for recent erosion and deposition is visible at all three trench sites. The presence of the faint northward sloping layer stretching from the top to the bottom of Trench 1, dating to $900 \pm 25$ years BP, suggests a paleoslope in the area that isn't there today. This would also suggest there was a large amount of deposition within the last 900 years to bury that paleoslope. A change in local base level in favor of sediment accumulation would be required for the slope burial, possibly accommodated by the lateral migration of the Yangyan River to the northeast. 
A notable similarity between all three trench sites is the lack of preservation of the most recent faulting event within the trench walls. If a change in base level were able to increase local sedimentation rates, it's possible that base level could change in favor of erosion as well. This could explain the absence of recent key stratigraphic units in Trenches 2 and 3. Both Trenches 2 and 3 show large erosional events in their stratigraphic history.

Lateral migration of the Yangyan River to the north of all three trench sites could explain the fluctuation between erosion and deposition visible in the trench walls. Southward migration of the river would bring the local base level closer to the mountain front, resulting in increased amounts of erosion along the fault scarp. A northward migration of the river would do the opposite, promoting deposition along the mountain front on a local scale.

Evidence of anthropogenic modification of the fault scarp in Trench 1 is shown by the near horizontal beds at the top of both trench walls (and the corn field in which the trench was excavated). Due to the position of Trench 1, either anthropogenic modification or erosion could be the cause for the lack of recent faulted stratigraphy.

Possible supporting evidence for recent increase in sedimentation rates is the presence of multiple large alluvial fans along the NWTSF within the study area that are not present along the NWTSF elsewhere in the basin. However, this could be due to the large amounts of loess present within the Daixian Basin restricting the deposition of sediment to within valleys cut into the loess (Figure 3.2). Loess deposits north of the fault scarp may have been eroded by the Yangyan River, allowing the formation of alluvial fans. Further study would be needed to determine if the lateral migration of the Yangyan 
River would be sufficient enough to provide the base level change needed for the paleoslope burial, the possible erosion of recently faulted stratigraphic layers and the removal of thick loess deposits adjacent to the fault scarp.

Another possibility for the lack of evidence for the 512 A.D. Daixian earthquake in our trenches is that the surface fault rupture did not reach this far northeast. However, with the erosion of recent strata in Trenches 1 and 3 and the lack of datable material in Trench 2, it is impossible to say for certain that strata older than 512 A.D. are present and not faulted in these trenches.

Despite the similarities between the three trench sites, they are in three separate locations on this segment of the NWTSF, each with different characteristics. Trench 1 is located on the northern branch of the fault bifurcation, with a hanging wall and footwall made up of fluvially derived gravels and thick beds of loess. Trench 3 is located to the east of Trench 1 on the main branch of the NWTSF, before the fault bifurcates. It consists of soils and gravels that were deposited on a slope coming off of the bedrock hillslopes just to the south of the trench. Trench 2 is located almost exactly between the two trenches, directly on the spot where the fault splits to the west. The sudden change between a single fault branch in the east wall of Trench 2 and multiple faults in the west wall just 2.5 meters away could evidence of the trench's location adjacent to, or on top of, the bifurcation of the main fault.

Trench 2 is also much more stratigraphically complex than the other two trenches, with its southward dipping gravel beds and stratigraphic dissimilarities between the east and west walls of the trench. Erosional and depositional influences from all directions could help explain the complexity. A combination of stream erosion along the fault scarp 
from a drainage to the east, deposition from the large alluvial fan to the north and the location of the trench on the tip of a rounded hillslope could have influenced the various north, south and westward dipping stratigraphy in both the east and west walls.

Overall, the individual stratigraphic interpretations for each trench and the formational history proposed for Trench 2 will help guide trench site selections in the future. The apparent increase in recent sediment accumulation in all trenches, the large amounts of erosion evident in Trenches 2 and 3 and the anomalous presence of large alluvial fans in the study area indicate this area is not suitable for paleoseismic trench investigation of recent faulting events. Other methods, such as tectonic geomorphological studies, may be more appropriate for this section of the NWTSF, though they lack the potential precision of a paleoseismic trench. Trench investigations to the west or the east of the study area may be more successful and would provide a good comparison to the processes evident in this study.

\section{B. Earthquake Hazard}

Estimated earthquake recurrence intervals, paleoseismic constraints and characteristic earthquake magnitudes are key in the assessment of earthquake hazard for a given region. The large paleoslope seen in Trench 1 provides a constraint for the paleoseismicity of that section of the fault. The slope is straight and continuous, stretching from the top to the bottom of the 8 meter tall trench at an angle of $\sim 29^{\circ}$. If this slope deposit had been present during movement on the fault it would have been folded due to the apparent change in angle of the main fault in Trench 1. This implies that, since the paleoslope has an age of $\sim 900 \pm 25 \mathrm{BP}$, the fault has not moved within that amount of time. 
The two possible relict terraces adjacent to Trench 2 yield estimated earthquake magnitudes of approximately 7.1M and 7.0-7.1M. These values are slightly less than the most recent recorded earthquake $(7.5 \mathrm{M})$ estimated from historical records, though overestimation of magnitudes from historical data is not uncommon (Ambraseys, 2009). Additionally, these magnitude calculations are very close to those recorded from paleoseismic trenches to the southwest along the NWTSF (7.0-7.1M) by Liu et al. (1991), which suggests our magnitude calculations are within an acceptable range for reasonable estimations of earthquake magnitude typical of the NWTSF.

Methods of error propagation (Geyh, 1990) were applied to values reported by Ding et al. (2010) on estimated timing of earthquake events in order to obtain a more statistically valid calculation for the average earthquake recurrence interval for the NWTSF (Table 4.2). Using these methods the average earthquake recurrence interval increased from $\sim 1400$ a to $2148 \pm 869$ years per event.

Taking into account earthquake magnitudes from Liu et al. (1991) as well as this study, an earthquake of magnitude $7.1 \mathrm{M}$ is assumed to be the characteristic earthquake magnitude for this fault. This would correspond to an earthquake with an average displacement of $\sim 3.3$ meters using the Wells and Coppersmith (1994) formula given in Chapter 3. Using the total displacement estimations in Trench $1(14-17 \mathrm{~m})$ as well as the total age for the displacement, an approximate earthquake recurrence interval for the fault can be calculated, resulting in a value of $3893 \pm 393$ years per event. This value is more than double than that reported by Ding et al. (2010)(Table 2.1) and still significantly higher than the recalculated values in Table 4.2. Since the calculated value is so different than the others, it may be that one or more of the assumptions made in the process of 


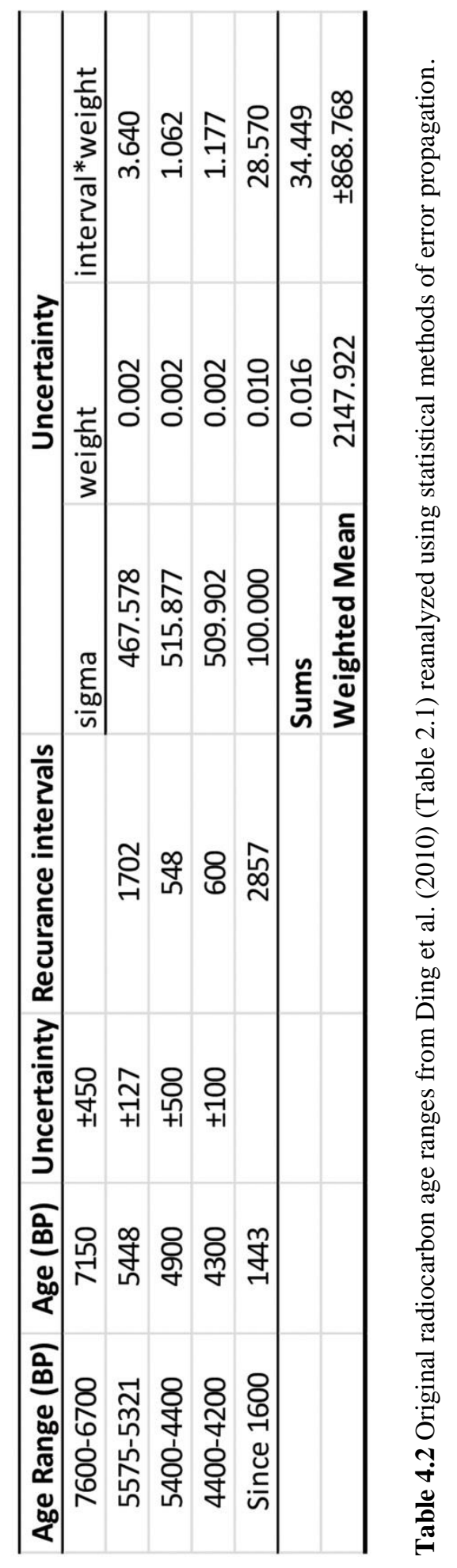


calculating the value is wrong.

Alternatively, the distance between the two trench locations $(\sim 20 \mathrm{~km})$ in Ding et al. (2010) and Liu et al. (1991) that are said to contain evidence of the 512 A.D. Daixian earthquake can be used to estimate a minimum earthquake magnitude for that event. Using the following formula from Wells and Coppersmith (1994):

$$
\mathrm{M}=4.86+1.32 * \log (\mathrm{SRL})
$$

where SRL is surface rupture length in kilometers and $\mathrm{M}$ is moment magnitude, the minimum estimate for the magnitude of the 512 Daixian earthquake is $6.6 \mathrm{M}$. Since the $20 \mathrm{~km}$ distance between these two trench sites is $\sim 1 / 4$ of the total length of the fault $(\sim 85 \mathrm{~km})$ a low magnitude is expected for this calculation. For comparison, if the entire length of the fault was used in the same formula the resulting magnitude would be $7.4 \mathrm{M}$.

Using the value for the average estimated earthquake recurrence interval in Table 4.2, a probabilistic earthquake analysis can be assessed for the area (Reiter, 1990). Assuming a characteristic earthquake and a Gaussian probability distribution, to assess the probability of an earthquake happening within the next 50 years, the probability that an earthquake will happen after 50 years from now was subtracted from the probability that an earthquake will happen after the current date. This resulted in a $1.8 \%$ probability that a magnitude $7.1 \mathrm{M}$ earthquake will occur on this section of the NWTSF within the next 50 years assuming a Gaussian probability distribution.

\section{Tectonics}

Calculations for slip rate along the fault in Trench 1, using at an average observed fault dip within the trench $\left(45^{\circ}\right)$ for a maximum slip rate and a typical dip of a normal fault $\left(60^{\circ}\right)$ for a minimum slip rate, yielded values between .8 and $.9 \mathrm{~mm} / \mathrm{year}$. This 
converts to horizontal extension rates of $0.4-0.7 \mathrm{~mm} / \mathrm{yr}$. GPS surveys reported by $\mathrm{He}$ et al. (2003) show that, within the uncertainties of the GPS velocities, there is no measurable extension across the Shanxi Graben System. This implies that if there is extension it would be less than the uncertainties of their data: less than $1.5 \mathrm{~mm} / \mathrm{year}$. The calculated extension rate in this study of $0.4-0.7 \mathrm{~mm} / \mathrm{yr}$ is consistent with the implied extension rate of less than $1.5 \mathrm{~mm} / \mathrm{yr}$ shown using GPS velocities.

Another estimation of slip rate can be calculated using the scarp profiles near Trench 2. The average slip per event seen in the scarp profiles is 2.7 meters. Dividing this value by the weighted mean earthquake recurrence interval from Table 4.2 results in a throw rate of $1.3 \pm 0.5 \mathrm{~mm} / \mathrm{yr}$. Assuming a fault dip of $60^{\circ}$ at depth (for comparison with values from Trench 1) the horizontal extension rate is $\sim 0.7 \mathrm{~mm} / \mathrm{yr}$. This value is at the high end of the extension rate found in Trench 1, and is still consistent with the extension rate implied by the GPS velocities. Taking into account the errors on the slip rate calculations there is no significant discrepancy between the two values. This implies that it is likely that strain on the faults is released through seismic activity.

In addition to the constraints on extension provided by the GPS velocity analysis by He et al. (2003), Wesnousky et al. (1984) used a 700 year historical record in conjunction with formulas relating crustal strain to the occurrence rate of seismic moment. They estimate a north to northwesterly extension of $0.5-1.0 \mathrm{~mm} / \mathrm{yr}$ across the Shanxi Graben System.

Zhang et al. (1998) estimated the uppermost Pliocene-Quaternary extension across the Shanxi Graben System to be $\sim 0.5 \pm 0.1 \mathrm{~mm} / \mathrm{yr}$. This estimate is close to estimates from this study as well as those of Wesnousky et al. (1984), and they are within 
the constraints implied from GPS velocities. This would suggest that tectonic activity in the Shanxi Graben System has remained fairly constant since the late Pliocene.

\section{Conclusions}

This study shows the complex interactions between fault structure and surrounding sedimentary processes, not only including the area immediately adjacent to the trench, but also further out, including influences from adjacent drainages cut into the mountain front. The complex three dimensional geometries observed in Trench 2, including gravel beds dipping with an antithetic sense to the thick loess paleosols dipping to the north in the upper part of either trench wall, show a change in the direction of erosion and deposition throughout the 6 meters of stratigraphy represented in the trench. The drainage to the east of the trench was deflected to the west by the large alluvial fan to the north, causing it to flow along the fault scarp. Gravels from the large alluvial fan were then deposited southward into the valley maintained by this deflected drainage, resulting in southward dipping stratigraphy within the trench walls.

Further complexity of the stratigraphy in Trench 2 is due to the location of the trench on the corner of a hillslope. The southern wall of the trench shows stratigraphy in an upside-down $\mathrm{V}$ shape along with multiple erosional surfaces suggesting the west and east walls of the trench had different sources of erosion and deposition. The discrepancy between a single fault bounding the bedrock at the southern end of the east wall and multiple faults present at the southern end of the west wall could be a result of the change in fault strike from $\sim 280^{\circ}$ on the east side of the trench to $\sim 240^{\circ}$ on the west side of the trench.

Large amounts of erosion and deposition are observed at the three trench sites. 
Radiocarbon ages greater than 20ka close to the current ground surface in Trench 3 suggest large amounts of erosion along the fault-bounded bedrock in the area surrounding the trench. Paleosols capping faulted stratigraphy in the west wall of Trench 2 suggest large amounts of deposition after equally large amounts of erosion. Trench 3 provides some age constraint on erosion adjacent to the fault scarp in the form of a paleoslope dated to $900 \pm 25 \mathrm{BP}$. This northward dipping stratigraphic layer appears to be unaltered and spans the 8-meter height of the walls, suggesting that there was a slope in this area that wasn't there before. This implies a large amount of deposition within the last $~ 900$ years as well.

In addition to evidence of erosion and deposition within the trenches, large exposed alluvial fans present throughout the study area are not observed in other portions of the NWTSF suggesting an increased rate of deposition in our study area. The lateral migration of the Yangyan River to the north of all three trench sites could be the cause of the large alluvial fans, as well as the fluctuation between erosion and deposition visible in the trenches on. A southward migration of the Yangyan River would bring the local base level closer to the mountain front, increasing the amount of erosion along the fault scarp. A northward migration of the Yangyan River would do the opposite, increasing the amount of deposition along the fault scarp.

In addition to natural erosion of the fault scarp, anthropogenic modification in the form of agricultural terracing is evident at all three trench sites. Stratigraphy in the upper 1-1.5 meters of Trenches 1 and 2 show a leveling of the surface linked to human modification. Recent human alteration of the area surrounding Trench 3 is quite evident as it was partially exposed by the terracing of an alluvial fan for a tree farm. Additional 
terracing is evident from satellite imagery in most surfaces that are not bedrock within the area.

Evidence of anthropogenic modification of the fault scarp and adjacent areas, the large amounts of erosion and deposition apparent in all three trenches and the anomalous presence of large alluvial fans in the study area indicate that this area is not suitable for paleoseismic trench investigation of recent faulting events. Other methods, such as tectonic geomorphological studies, may be more appropriate for this section of the NWTSF. Trench investigations to either the west or east of the study area may be more successful, and would provide a good comparison to the processes evident in this study.

Paleoseismic constraints, fault magnitudes and earthquake recurrence intervals assist in the general hazard assessment of the region. The unmodified appearance of the paleoslope in Trench 1 provides a paleoseismic constraint on the activity of the NWTSF in the area, showing that the fault was not active at least for the past 900 years. Faulted relict fluvial terrace surfaces near Trench 2 yielded scarp heights of 2.9 and 5.4 meters. Assuming these two vertical offsets are representative of the last and last two earthquake events on this fault respectively, a vertical offset of $2.9 \mathrm{~m}$ is inferred for the ultimate event while a vertical offset of $2.5 \mathrm{~m}$ for the penultimate event was calculated by differencing the two scarp heights. Magnitudes for these two events were calculated (7.1M and 7.07.1M) using the empirical relationships in Wells and Coppersmith (1994). This suggests a characteristic magnitude estimation of $\sim 7.1 \mathrm{M}$ for earthquakes along the NWTSF, which is consistent with previously published data (Liu et al., 1991).

Palinspastic reconstructions of the stratigraphy in Trench 3 show offsets of 0.69 and 0.91 meters for two separate earthquake events. These offsets are significantly lower 
than those recorded from offset terraces near Trench 2. This is likely due to additional slip having been accommodated on other faults not visible in the trench due to its small size.

Using statistical methods of error propagation, earthquake age estimates from Ding et al. (2010) were reexamined to obtain an average earthquake recurrence interval of $2147 \pm 869$ years for the fault. Using this value, a $1.8 \%$ probability of an earthquake on this portion of the NWTSF within the next 50 years was calculated assuming a characteristic earthquake and a Gaussian probability distribution of earthquake recurrence.

By dividing the average vertical displacement of the last two events determined from the scarp profiles near Trench 2 by the average earthquake recurrence interval, a slip rate of $\sim 1.3 \pm 0.5 \mathrm{~mm} / \mathrm{yr}$ was obtained. This converts to a horizontal extension rate of $\sim 0.7 \mathrm{~mm} / \mathrm{yr}$. An additional horizontal extension rate of $0.4-0.7 \mathrm{~mm} / \mathrm{yr}$ was calculated from the restoration of a $\sim 19 \mathrm{ka}$ BP paleosol in the hanging wall of Trench 1 to the top of the fault scarp, interpreted as the T2 surface as reported in Zhang et al. (2007), which has an age of $18 \pm 0.9 \mathrm{ka} B P$.

GPS velocity measurements show no apparent extension across the Shanxi Graben System within the uncertainties of their data $(>1.5 \mathrm{~mm} / \mathrm{yr})(\mathrm{He}$ et al., 2003). This implies that if there is extension across the graben system it would be less than the uncertainties of their data; less than $1.5 \mathrm{~mm} / \mathrm{yr}$. This is supported by estimates of horizontal extension rates from this study. Additionally, horizontal extension rates from the upper Pliocene to Quaternary reported by Zhang et al. (1998) are also similar $(0.5 \pm 0.1$ $\mathrm{mm} / \mathrm{yr}$ ), which suggests the Shanxi Graben System has seen a consistent rate of extension 
since at least the Late Pliocene. Additionally, all slip in the upper crust in general is accommodated by episodic earthquake displacements. 


\section{References}

Ambraseys, N. (2009). Earthquakes in the Mediterranean and Middle East. New York, NY; Cambridge University Press

Ding, R., Ren, J., \& Zhang, S. (2010). Late Quaternary Activity and Paleoearthquakes along the Nanyukou Segment of the Northern Piedmont Fault of Wutai Mountain. Earthquake Research In China, 24(1), 82-96.

Geyh, Mebus A., \& Schleicher, Helmut (1990). Absolute Age Determination. (M.A. Geyh, Ed.), Springer-Verlag Berlin Heidelberg.

He, J., Liu, M., \& Li, Y. (2003). Is the Shanxi rift of northern China extending? Geophysical Research Letters, 30(23), 5-8. doi:10.1029/2003GL018764

Kroner, a, Wilde, S., Li, J., \& Wang, K. (2005). Age and evolution of a late Archean to Paleoproterozoic upper to lower crustal section in the Wutaishan/Hengshan/Fuping terrain of northern China. Journal of Asian Earth Sciences, 24(5), 577-595.

Kusky, T., \& Li, J. (2003). Paleoproterozoic tectonic evolution of the North China Craton. Journal of Asian Earth Sciences, 22(4), 383-397.

Kusky, T. M., Windley, B. F., \& Zhai, M.-G. (2007). Tectonic evolution of the North China Block: from orogen to craton to orogen. Geological Society, London, Special Publications, 280(1), 1-34.

Kusky, Timothy M. (2011). Geophysical and geological tests of tectonic models of the North China Craton. Gondwana Research, 20(1), 26-35.

Li, Y., Yang, J., Xia, Z., \& Mo, D. (1998). Tectonic geomorphology in the Shanxi Graben System, northern China. Geomorphology, 23(1), 77-89.

Liu, G., Yu, S., Zhang, S., Dou, S., Xu, Y., \& Fan, J. (1991). The North Wutaishan Piedmont Active Fault Zone in Shanxi. Research on Active Fault, 1, 118-130. (In Chinese with English abstract)

Liu, M., Stein, S., \& Wang, H. (2011). 2000 years of migrating earthquakes in North China: How earthquakes in midcontinents differ from those at plate boundaries. Lithosphere, 3(2), 128-132.

Liu, Mian, Shen, Z., Wang, S., Wang, M., \& Wan, Y. (2007). Active tectonics and intracontinental earthquakes in China: The kinematics and geodynamics. The Geologic Society of America Special Paper 425, 19, 299-318.

doi:10.1130/2007.2425(19). 
McCalpin, J. P., Carver, G. A., Goldfinger, C., Hacket, W. R., Jibson, R. W., Nelson, A. R., Obermeier, S. F., et al. (2009). Paleoseismology. (J. P. Mccalpin, Ed.) (Second Edi.). Burlington, MA: Academic Press.

Reiter, Leon (1990). Earthquake Hazard Analysis. (J. P. Mccalpin, Ed.) NewYork, NY: Columbia University Press

Shen, Z., Zhao, C., Yin, A., Li, Y., Jackson, D. D., Fang, P., \& Dong, D. (2000). Contemporary Crustal Deformation In East Asia Constrained By Global Positioning System Measurements. Journal of Geophysical Research, 105(B3), 5721-5734.

Wang, Q. (2003). Current crustal movement in Chinese mainland. Acta Seismologica Sinica, 16(5), 574-582. doi:10.1007/BF02893478

Wells, D. L., \& Coppersmith, K. J. (1994). New Empirical Relationships among Magnitude, Rupture Length, Rupture Width, Rupture Area, and Surface Displacement. Bulletin of the Seismological Society of America, 84(4), 974-1002.

Wesnousky, S. G., Jones, L. M., Scholz, C. H., \& Deng, Q. (1984). Historical Seismicity and Rates of Crustal Deformation Along the Margins of the Ordos Block, North China, 74(5), 1767-1783.

Xu, X., Ma, X., Deng, Q., Liu, G., \& Ma, Z. (1993). Neotectonics, Paleoseismology and Ground Fissures of the Shanxi (Fen-Wei) Rift System, China. 30th IGC Field Trip Guide (pp. T314.1 - T314.152).

Zhang, S., Ren, J., \& Nie, G. (2007). Paragenesia of Quaternary pediments and river terraces on the north piedmont of Wutai Mountains. Chinese Science Bulletin, 52(4), $521-530$.

Zhang, Y. Q., Mercier, J. L., \& Vergely, P. (1998). Extension in the graben systems around the Ordos (China), and its contribution to the extrusion tectonics of south China with respect to Gobi-Mongolia. Tectonophysics, 285, 41-75.

Zhao, G., Kröner, A., Wilde, S. a., Sun, M., Li, S., Li, X., Zhang, J., et al. (2007). Lithotectonic elements and geological events in the Hengshan-Wutai-Fuping belt: a synthesis and implications for the evolution of the Trans-North China Orogen. Geological Magazine, 144(05), 753-775.

Zheng, T., Zhao, L., \& Zhu, R. (2009). New evidence from seismic imaging for subduction during assembly of the North China craton. Geology, 37(5), 395-398. 